\title{
CONTENTS
}

\section{DIVERSITY, INTEGRATION AND CITIZENSHIP}

$1 \quad$ Adam Berryman and Kate Mitchell

5 Dora Horvath

29 Mark Nolan and Kim Rubenstein

47 Julie Thorpe

49 Vesna Drapac

77 Stefan Markowski
Introduction: Diversity, integration and citizenship

Tracing cosmopolitan strands in EU citizenship: A postmodern idea?

Citizenship and identity in diverse societies

Population politics in the fascist era: Austria's 1935 population index

Active citizenship in multicultural Australia: the Croatian experience

Citizenship and integration: A snapshot of the Polish migrant community in Australia 



\section{CONTRIBUTORS}

ADAM BERRYMAN

VESNA DRAPAC

DORA HORVATH

STEFAN MARKOWSKI
Adam Berryman is a graduate of La Trobe University and was the 2006 Australian postgraduate visiting fellow at the European University Institute in Florence. He previously taught European politics at the University of Melbourne and is now based at The Australian National University, where he is a visiting scholar at the National Europe Centre in the Research School of Humanities. Adam's research interests include European integration, migration and multiculturalism in contemporary Europe.

Vesna Drapac teaches modern European history at the University of Adelaide. Her research interests include social, cultural and religious responses to war and occupation in Hitler's Europe and comparative historiographies of World War II. She also works on the history of Croatian immigration to Australia. Her first book, War and Religion:

Catholics in the churches of occupied Paris, was published in 1998 and her forthcoming book, Constructing Yugoslavia: A transnational history, is contracted to Palgrave.

Dora Horvath is a PhD candidate at the University of Melbourne and holds a Masters Degree in International Relations from the Corvin University, Budapest, Hungary. Her research interests include cosmopolitanism and postmodernism, citizenship and multiculturalism, rhetorical representations of belonging and European integration. She has extensive experience in grant and project development and management in the education and the private business sectors. She is currently the centre coordinator of the National Europe Centre in the Research School of Humanities at The Australian National University.

Dr Stefan Markowski lectures at the School of Business, the University of New South Wales at the Australian Defence Force Academy (UNSW@ADFA), Canberra. He graduated from the University of Warsaw and holds a PhD from the London School of Economics, where he started his professional career as a lecturer in economics. In the United Kingdom, Stefan also worked as a 
KATE MITCHELL Dr Kate Mitchell holds a PhD in literary studies from the University of Melbourne and a BA (Hons) in English and history from The Australian National University. She is currently a visiting fellow at the National Europe Centre in the Research School of Humanities at The Australian National University and teaches within the College of Arts and Social Sciences. Her research is focused on nineteenth and twentieth-century literary and cultural history, with a particular interest in neo-Victorian fiction and historical recollection in fictional narratives. She has published articles that examine the representation of history and historical recollection in neo-Victorian novels by Graham Swift, A. S. Byatt, Helen Humphreys and Gail Jones. Her first monograph, Victorian Afterimages, will be published by Palgrave in late 2009.

MARK NOLAN Dr Mark Nolan (BSc [Hons], LLB, PhD [ANU]) is a senior lecturer at the College of Law, The Australian National University. After researching and teaching social psychology at the School of Psychology at The Australian National University, Mark joined the ANU College of Law in 2002 and researches and teaches law (primarily criminal law and military discipline law) and interdisciplinary legal psychology. Mark designed and teaches The Australian National University's first Law and Psychology course to law students. His PhD in social psychology was an empirical study of social identity, perceived injustice and the use of human rights law. Other research interests include criminal law and procedure, inter-group relations, justice, 


\section{KIM RUBENSTEIN}

counter-terrorism law and procedure and comparative law including Japanese jury reforms.

Kim Rubenstein is Professor and Director of the Centre for International and Public Law at the ANU College of Law. A graduate of Melbourne and Harvard Universities, her research concentrates on citizenship law, nationality and women and constitutional law. Before becoming an academic, Kim practised as a solicitor and she has appeared during her academic career in several High Court citizenship matters. Kim edited the collection Individual, Community, Nation: 50 years of Australian citizenship (Australian Scholarly Publishing 2000) and is the author of Australian Citizenship Law in Context (Lawbook Company 2002). In 2008, she was appointed a member of the independent committee reviewing the Australian Citizenship Test, which reported to the Minister for Immigration and Citizenship with suggestions for reform.

JULIE THORPE Dr Julie Thorpe holds a BA and PhD from the University of Adelaide. She has lectured in the history programs at the University of Adelaide and at The Australian National University. In 2007, she was awarded a visiting scholarship to the National Europe Centre at The Australian National University and currently holds a joint postdoctoral fellowship with The Australian National University and the University of Konstanz. Her research interests include nineteenth and twentieth-century Central European history, nationalism, political culture and fascism in Austria. Her first monograph, about nationalism in the Austro-fascist state (1933-38), is under contract to Manchester University Press. She is currently working on a project that focuses on wartime refugees in the Austro-Hungarian Empire during World War I. 



\title{
INTRODUCTION: DIVERSITY, INTEGRATION AND CITIZENSHIP
}

\author{
ADAM BERRYMAN AND KATE MITCHELL
}

This issue of Humanities Research had its genesis in the European Diaspora Research Network, an initiative of the National Europe Centre at The Australian National University and Victoria University in Melbourne. ${ }^{1}$ The network was founded with the aim of connecting scholars from a variety of disciplines with relevant policy practitioners and migrant-community leaders to facilitate collaborative research. The primary activities of the network culminated in 2006, with a capstone international conference that explored the links and synergies between European diasporic communities in Australia and the continuing processes of European integration.

One of the core research themes of the network was citizenship. More specifically, researchers engaged with the changing nature of citizenship in an era of increased international mobility, a progressively globalised economy and the formation of supranational political entities such as the European Union. In the current context older questions were revisited with renewed urgency. How do political discourses shape national identities? What are the most effective means of integrating cultural, ethnic and religious minorities? What type, or degree, of (political) recognition aids integration and what level of recognition becomes counterproductive to social cohesion, provoking divisions within host societies?

The articles in this volume analyse citizenship with a view to better understanding its potential to accommodate ethnic diversity and promote social integration. In doing so, they raise and seek to address a series of questions regarding the political uses of citizenship and its legitimising function for individuals, minority groups and political authorities. To this end, the volume can be loosely divided into two parts. The first addresses 'topdown' approaches to citizenship that have developed within Europe and Australia, examining the ways in which political constructs of belonging are translated into policy and law. The second section reflects a more 'bottom-up' analysis of the response of European diasporas to the conditions and provisions of Australian society and citizenship.

In the first article, Dora Horvath looks at citizenship within the European integration project. The European Union (EU) has introduced a multilevel citizenship regime, aimed at enhancing supranational legitimacy and developing a stronger sense of European identity. The article examines the constitutional basis of EU citizenship through a cosmopolitan lens, identifying the different streams of cosmopolitan thought within the treaties that form the legal basis for European integration. Tra- 
cing an arc of cosmopolitan philosophy from Kant to Habermas, the article highlights some of the reasons why the European Union has become the case study par excellence for cosmopolitanists in the past two decades. It points out, however, that postmodern conditions require new forms of citizenship that accommodate not just cosmopolitan universalism, but multiculturalism - a diversity of political and cultural traditions - and transnationalism, the active engagement of citizens in a postnational context. Although there is much within the treaties to encourage a cosmopolitan understanding of EU citizenship, Horvath explains why it has done little to legitimise Brussels elites or build support for deeper political integration in Europe.

In their article 'Citizenship and identity in diverse societies', Mark Nolan and Kim Rubenstein explore the recent changes to Australian citizenship law and its impact on the acceptance of blended identities in Australia. Drawing on legal analysis of Australian citizenship and psychological research on identity, they argue that recent citizenship policy reforms represent a backward step in terms of understanding complex, blended identities in Australia. They question the assumption, implicit within the new citizenship law, that the testing of language proficiency and civics knowledge, together with the endorsement of Australian values, will successfully encourage the formation of simple, single Australian national identity-and they further contest the desirability of such an outcome. This article highlights some of the shortcomings of the 2007 Australian Citizenship Act, notably the inconsistency between the introduction of testing to encourage a singular notion of national identity and the established legal provi- sion for dual or multiple citizenship. The article's psycho-legal approach underlines the legitimising effect of legal processes relating to citizenship, providing insights as to how the application for and acquisition of citizenship in Australia works to (de)-legitimise an individual's desired selfdefinition. In doing so, it provokes a series of broader questions about the political uses of citizenship and its relationship with identity formation.

In keeping with the European Diaspora Research Network's promotion of interdisciplinary collaboration, the third article in this volume takes a historical perspective. Making interwar Austria her case study, Julie Thorpe subverts the conventional distinction between 'authoritarian' and 'fascist' states, positioning herself among a number of historians who suggest that it is more useful to plot these states on a spectrum of radical right-wing tendencies. Such an approach focuses on processes rather than outcomes and approaches fascism as an extension of other policies that seek to control the citizens of a given state. To this end, her article examines public debates about the 1935 proposal for an Austrian population index, modelled on fascist Italy's legislation. Thorpe situates Austria within a particular constellation of post-imperial state-building discourses, including exclusionary ultra-nationalism and aggressive, racially motivated population politics, which was a stimulus for and reaction to waves of intracontinental migration. By highlighting the roots of Austria's extreme nationalist discourse and the population policy it prompted, Thorpe illustrates the political foundations of European intolerance in the twentieth century. Placed alongside the other articles in this volume, Thorpe's 
historical perspective enables us to identify residual elements of this nationalist project in contemporary political discourses regarding immigration and multiculturalism.

In the final two articles, the focus shifts to immigrant communities in Australia. These articles contribute to recent research that challenges the assumption that a diaspora's connection to their country of origin weakens over time. Instead, several scholars have recently suggested that in an era of globalisation many diasporas are now redefining and reinforcing their identification with their homeland (see, for example, Dufoix 2008; Fullilove 2008). Vesna Drapac aptly illustrates this in her examination of the experience of Croatian immigrants in the context of debates about Australian multiculturalism. Focusing on those who arrived in the first two waves of post-1945 immigration, she argues that the active citizenship and associational practices of this group led to their successful integration into Australian society, but that this was coupled with the retention of elements of Croatian cultural identity. She suggests that the mobilisation of the Croatian community in Australia in response to the political upheaval and violence engendered by the collapse of Yugoslavia in the 1990s demonstrates the extent to which this group attaches themselves to the democratic ideals and processes of their adoptive country. Significantly, Drapac notes this group's paradoxical success in gaining greater recognition for a Croatian national identity before the official recognition of the Croatian State by the Australian Government or the international community.

The final article, Stefan Markowski's 'Citizenship and integration: a snapshot of the Polish migrant community in Australia', draws on survey and census data to argue that Polish immigrants have blended well into Australian society. The data presented here suggest that Polish immigrants to Australia claim a strong sense of Australian national identity and that they score well on traditional measures of integration, such as language proficiency and citizenship uptake. Markowski points out that, in this sense, Polish immigrants represent the type of migration that Australian policymakers have sought to attract. He acknowledges that there is still a tendency for Polish migrants and their descendents to retain or seek Polish citizenship, the value of which has increased since Poland joined the European Union. He argues, however, that this is more a matter of convenience - to facilitate ease of travel between Europe and Australia, for instance - rather than any sense of political belonging or overt loyalty to the Polish nation, supported by the fact that there has been minimal return migration to Poland.

Markowski engages directly with the argument put forward by Nolan and Rubenstein in this volume regarding the recent reforms of Australian citizenship policy. He acknowledges that the engineering of citizenship as a tool primarily for migrant integration has to some extent devalued citizenship for the broader Australian community but is much less critical of the notion of a 'uniform' national identity promoted via the 2007 Australian Citizenship Act. He argues that some sense of uniformity is logically necessary, but need not be considered intolerant of social diversity or mutually exclusive with hybrid, or blended, identity. 
What this issue of Humanities Research seeks to do, then, is draw together a range of disciplinary approaches and multivalent perspectives on the important role citizenship plays - symbolically, socially and legally - in integrating a state's population and shaping the identity of individuals, communities and nations. Although the articles articulate diverse positions on these issues, they nonetheless gravitate to a central concern: in an age of globalisation and multiculturalism, how can democratic states, or supranational constellations of states, uphold a notion of citizenship that fosters social cohesion while also legitimising diversity?

\section{REFERENCES}

Dufoix, Stephane 2008, Diasporas, University of California Press, Berkeley.

Fullilove, Michael 2008, World Wide Webs: Diasporas and the international system, Lowy Institute for International Policy, Sydney.

\section{ENDNOTES}

1 The network was funded by an EU Jean Monnet Reflection Activities Grant (No. 2005 1894/001-001), 'European Diaspora Research Network in Australia', and by The Australian National University and Victoria University. 


\title{
TRACING COSMOPOLITAN STRANDS IN EU CITIZENSHIP
}

\author{
A postmodern idea?
}

\section{DORA HORVATH}

\section{INTRODUCTION}

The European integration project is, to date, the world's most advanced post-national constellation of states. As such it has become a default case study and, at times, a quasi laboratory for political theorists and philosophers who are interested in studying and developing workable models of supranational and/or global governance. Prominent among these scholars are those who view the European Union (EU) through a cosmopolitan lens, analysing integration for its potential to contribute to a Kantian brand of universal egalitarianism. Such analyses are further encouraged by European elites who employ heavily normative rhetoric that reflects many of the tenets of cosmopolitan thought.

In practice, the European Union has evolved from a functional, utilitarian and largely economic project to a more complex political enterprise. The political framework for a broader and deeper integration of European states was established in the Treaty on European Union (also known as the Maastricht Treaty). In addition to consolidating the single market and opening the way for greater cooperation on internal and foreign affairs, this document also introduced the status of EU citizenship. This was not intended to replace national citizenship but rather to complement it and, in doing so-it was hoped - enhance the legitimacy of Brussels elites and promote a stronger European identity.

Although the labelling of European citizenship as cosmopolitan is far from explicit or coherent in EU policies and narrative, proto-cosmopolitan doctrines of universal and general equality ${ }^{l}$ are expressed by EU initiatives. It is claimed that European citizenship provides equal access to the individual-based legal status of union citizenship to all nationals, and universal civic protection to all nationals and residents, and this is to translate into a transcendent European identity. But is the cosmopolitan shaping of the European Union's common citizenship policy conducive to its underlying objective of legitimating the emerging European polity and creating an integrated European public?

This article engages directly with the proto-cosmopolitanist arguments in order to assess the relative legitimating potential of EU citizenship. In the first section, I review the evolution of contemporary cosmopolitan thought, highlighting in partic- 
ular its relevance for the postmodern conceptualisation of citizenship. The viability of cosmopolitan frameworks rests on their ability to facilitate a new understanding of citizenship that is emerging from the globalised conditions of post-national multiculturalism and transnationalism. This section also demonstrates that the scope of scholarly research in these fields overlaps with European integration studies, supporting claims that the European Union represents the first proto-cosmopolitanist postmodern polity. In the second section, the paper identifies and investigates the main developmental phases of the European Union's common citizenship agenda. This section acknowledges the rhetorical use of cosmopolitanism by the Brussels elites; nonetheless, its primary focus lies in assessing the proto-cosmopolitanist threads in the treaties of the European Union.

The article concludes by acknowledging the existence of cosmopolitanist threads in the European Union's common citizenship policy. It questions, however, whether EU citizenship has the simultaneous ability to include all Europeans (cosmopolitanist), to accommodate diverse citizenship practices (post-national multiculturalist) and embrace emerging new and deliberative formations of citizenship (transnationalist). There are two observations that stem from this conclusion: first, that the integrative capacity of the current European citizenship regime is strictly limited; and second, that the cosmopolitan framing of EU citizenship has potentially contributed to the European Union's legitimacy deficit. These critiques also point to generic shortcomings of cosmopolitan ideology.

\section{COSMOPOLITAN CITIZENSHIP AND POSTMODERNITY}

The scholarly exploration of the European Union's evolving citizenship regime takes place within an intellectual territory that is framed largely by debates surrounding globalisation and contemporary cosmopolitan ideology. By the 1990s, globalisation studies developed a set of new conditions for the postmodern re-conceptualisation of citizenship. ${ }^{2}$ Cosmopolitanism emerged as a suitable ideological framework to accommodate these new conditions. ${ }^{3}$ Academics and European policymakers thus often present the European integration project as a viable forum for the cosmopolitan conceptualisation of postmodern citizenship and further propose that the cosmopolitan framing of European citizenship has the potential to enhance the European Union's viability, legitimacy and integrative capacity. 4

The end of modernity: postmodern conditions of citizenship

Scholars concerned with the impact of globalisation have come to a common understanding that the modernist premises of the national state have been eroded. ${ }^{5}$ The Westphalian state is no longer the singular unit of political power with absolute sovereignty. There exist quasiautonomous political entities that nurture embryonic rights regimes and democratic institutions beyond the State. The nation is neither culturally homogenous nor the primary expression of collective identity. National communities are diverse; the individual's identity is multiple. Therefore, the modernist paradigm of citizenship that has had long symbiotic existence with the national state needs rethinking. The new 
postmodern conceptualisation needs to express the multiplicity of citizenship as a politico-legal status (post-nationalism), accommodate diverse and multiple identities (multiculturalism) and facilitate the citizens' political activism on all levels of sovereignty (transnationalism).

In parallel, the heightened post-worldwar awareness of the need for 'global planning, global knowledge and the recognition of a shared future' 6 restored interest in universal conceptualisations of belonging and institutional expressions of global norms. In the immediate absence of available conceptual frameworks to understand and respond to these challenges, the Kantian ideology of cosmopolitanism was resurrected. The contemporary expressions of cosmopolitanism are noted to represent a logical accommodation of the postmodern challenges to citizenship. Cosmopolitanism is depicted as the expression of a post-national multiculturalist model of political community, which preserves national and also facilitates global, regional and municipal loci of legal status and political membership. ${ }^{7}$ It is also transnationalist, in that it promotes an active citizenry that is empowered within a global civil society and enabled to shape the political future and the socio-cultural facet of their communities. ${ }^{8}$ The next section provides an abbreviated overview of cosmopolitan philosophy, highlighting critical junctures in its evolution and examining its relevance for the development of postmodern concepts of citizenship.

\section{The Kantian theorem of cosmopolitan- ism}

A common reference point for contemporary cosmopolitanists is the Enlightenment philosophical works of Immanuel Kant. ${ }^{9}$
Immanuel Kant's cosmopolitanist theor$\mathrm{em}^{10}$ was built around the vision of world peace. Kant proposed that the forming of a global ethical regime would eliminate the possibility of war, without the need to form a world state. The cornerstones of his normative order were the establishment of cosmopolitan law and the republican grooming of states.

Kant outlined a tripartite system of jurisprudence that contained a new type of jurisdiction-cosmopolitan law-in addition to domestic and international law. For Kant, cosmopolitan law was of a fundamentally different type of jurisdiction. The domestic law of a particular state contained rights and duties that regulated the individual citizens' relationships with fellow citizens as well as the State. International law was to police states only, and thus governed state-to-state relations. Cosmopolitan law was to consist of rights and duties that regulated 'the relation of individual persons of one state toward the individuals of another, as well as toward another state as a whole', ${ }^{11}$ regardless of national origin or state citizenship.

Individual rights under the umbrella of Kant's cosmopolitan law also differed from citizenship rights in domestic law. First, the individual's access to cosmopolitan rights rested on the individual's natural belonging to humanity, a much wider justification than the individual's alliance with a particular state. Second, the notion of cosmopolitan rights was also unique in that it attempted to articulate a normative ideal in response to ethical problems that were raised by the organic transformation of the world order and the resulting heightened sense of global interconnectedness. ${ }^{12}$ These new conditions called for new legal and institutional frameworks 
and ultimately made cosmopolitan law ethically desirable and empirically necessary. With the idea of cosmopolitan rights, Kant sought to regulate this new type of relationship between the State and foreigners. Kant's primary aim was to guarantee the 'conditions of universal hospitality' defined as 'the right of a stranger not to be treated with hostility when he arrives on someone else's territory'. ${ }^{13}$ Thus, for Kant, hospitality was not based on philanthropy but a legal and universal right. ${ }^{14}$

As for the institutionalisation of cosmopolitan law and rights, Kant rejected the idea of a world state. ${ }^{15}$ Instead, Kant embraced the modern era's principle of non-intervention and reinforced the ideal of 'self-policing individual states'. ${ }^{16} \mathrm{He}$ proposed the establishment of a cosmopolitan world order centred on the congress of free states, whereby state cooperation was a regulative but not a constitutive principle. Externally, this meant the voluntary federative cooperation of independent states: 'a united power and law-governed decisions of a united will' . ${ }^{17}$ Internally, this referred to the consolidation of the republican and representative democratic traditions of government. ${ }^{18}$ Kant reasoned that democratic states did not go to war and therefore the establishment of 'domestic justice' 19 was a sufficient precondition for the federal cooperation of states. Once the federative cooperation of the states is facilitated, a cosmopolitan ethical order to guarantee the 'cosmopolitan condition of general political security ${ }^{20}$ is likely to emerge.

Kant's cosmopolitan law and world order fundamentally shaped Kant's notions of cosmopolitan citizenship. First, Kant's interpretation of the right to universal hospitality was grounded in the natural right to exercise trading activity - that is, in the temporary, sporadic and trade-focused interactions among the foreigners, and the State and its citizens. Only those foreigners who passed through or resided in another state for the specific purpose of trading were entitled to cosmopolitan rights. ${ }^{21}$ Second, Kant's rejection of the need to institutionalise cosmopolitan law beyond the State meant that guarantees for generating, implementing, enforcing and upholding cosmopolitan rights relied primarily on the State's ethical commitment to cosmopolitan ideals, rather than on the sovereignty of supra and supernational institutions. According to these two conditions, the State's responsibility towards non-citizens was simply to provide the conditions of hospitality - that is, a limited form of civil protection to enable their economic activity. This further meant that the rights of citizens and of foreigners were to be kept separate. Despite the expression of its global and universal scope, cosmopolitan law was not considered to have the competence to override domestic law and grant foreigners access to civic and political rights associated with state citizenship. In short, Kant's cosmopolitan citizenship was more an expression of global collective identity than a constitutionalised politico-legal status of universal belonging. 22

It is evident that Kant's theorem was grounded in the modernist rather than the postmodernist understanding of citizenship. In the absence of inter and supranational legal and institutional frameworks for citizenship, it falls short of post-nationalism. As the cosmopolitan ethical order is conditioned on the states' cooperative activity and democratic ability, it is also deficient in terms of transnational cit- 
izenry activism. As it is focused on the universal sameness of all, it does not engage with the notion of cultural diversity. Further to this, Kant's cosmopolitan citizen is also an inconsistent notion. The cosmopolitan ideology and the modern paradigm of citizenship are founded in the liberal principles of individualism, egalitarianism and universalism. As Kant's cosmopolitan rights are limited in content and in terms of access, it serves only as a fragmented category that fails to fulfil universal and individual equality.

\section{Liberal national and universal cosmo- politanism}

In the recent globalised context, cosmopolitan thought has flowed into several core streams, two of which - universalism and liberal nationalism-have preserved a common root in the Kantian traditions. ${ }^{23}$ Despite their shared legacy, liberal nationalism and universal cosmopolitanism differ fundamentally. Liberal cosmopolitanism embraces the Kantian limitations on political cosmopolitanism and proposes that normative cosmopolitanism is best expressed and maintained within the national context. As such, liberal nationalism is often mistaken as being anti-cosmopolitanism. However, what liberalists in fact foster is the cosmopolitanist remodelling of the national state so that basic principles of liberalism can be reconciled with multicultural diversity. ${ }^{24}$

The universalist position promotes the expression of global morality in the form of supranational legal systems and political institutions. It is founded on the belief that the ideology of cosmopolitanism and the modern national state-based theory of citizenship differ fundamentally. Universalists also claim that cosmopolitanism is su- perior, or at least more valid, in the context of the postmodern conditions. As they promote the politico-institutional establishment of the cosmopolitan ideal, the universalist stream is rightly labelled as the 'radical extension of Kant's theory of world citizenship'. 25

The article proceeds with a focus on the universalist stream of cosmopolitan thought, as it is the universalists who are engaged with the European traditions of the cosmopolitan theory of citizenship and the development of the institutional and the ethical frameworks of cosmopolitan citizenship - both of which are already established to some degree in the European Union. Universalists trace a developmental arc of contemporary cosmopolitan thought from a singular to a hybrid and multilayered expression of sovereignty and identity, and from international rights to European citizenship as the manifestation of the cosmopolitan idea.

\section{The cosmopolitan democracy thesis}

A major contribution to the universalist stream is the theory of cosmopolitan democracy, centred on David Held's idea of global governance. Held argues that the realisation of the cosmopolitan vision, that of lasting world peace and universal equality of individuals, cannot rely on the states' democratic capacity only. As a result of globalisation, the locus of political power can no longer be assumed to be with the State. Therefore, the State on its own cannot generate the conditions of democracy within its boundaries and then transfer the democratic principle into the international domain. Thus Held argues that, for 'democratic law to be effective it must be internationalised'. ${ }^{26}$ 
A regular collaborator with Held, Daniele Archibugi, elaborates on Held's new democratic condition. Archibugi argues that an international system that is based on democratic principles does not necessarily generate democracy within the constituting states. Therefore, democracy has to function simultaneously on all levels of political authority-domestic, international and global - in order to generate a lasting normative framework in each domain. In short, Archibugi's vision of the cosmopolitan world order is one of a multilevel system of democratic governance. ${ }^{27}$

Therefore, Held's and Archibugi's recreation of Kant's tripartite jurisprudence exceeds the Kantian global order in many respects. The democratic requirements of domestic law subscribe to the Kantian idea of republican democracy in the State. The international requirement of democracy is no longer purely reliant on the respect for reciprocal sovereignty between states; it rests on two additional criteria: the agreement on commonly shared norms to which states subscribe and the institutionalisation of these principles through the establishment of intergovernmental organisations. 28 Further to this, the global (or cosmopolitan) domain is not restricted to the universal right of 'hospitality for strangers' but a more comprehensive, and state-like, package of rights.

Based on this new conditionality for democracy, it is thus clear that the cosmopolitan democracy theory moves away from Kant's purely ethical to a more constituting and institutionalised world order. For Held and Archibugi, the entrenchment of democratic institutions outside of the boundaries of the State is indeed necessary in order to complement the inadequate democratic capacities of the postmodern state $^{29}$ and to monitor the domestic affairs of states. ${ }^{30}$ Universalist scholars emphasise that the cosmopolitan argument for the federative development of the global domain is not a call for the establishment of a global federation in the traditional sense. As Held notes, 'any global legislative institution should be conceived above all as a "framework-setting" institution', and not a nascent global government of an emergent world state. ${ }^{31}$

Further to this, cosmopolitan democracy also means the active membership of individuals in the global community. 32 Global issues, such as human rights, the environment and poverty, have a universal impact on all individuals, and as such, transcend national and international frameworks of cooperation. If global challenges are to be addressed in line with basic democratic principles, citizens shall have political representation in global affairs. This representation shall be independent and autonomous of the citizens' politico-legal status in domestic affairs. The citizen of the postmodern and globalised epoch has 'a twofold role - that of citizens of the state, and that of citizens of the world'. ${ }^{33}$ Held and Archibugi argue that this requires the establishment of global bodies that are designed to facilitate the deliberation of individual interests in specific global issues. It further involves the institutionalisation of a universal and global citizenship status, which contains 'a mandatory core of rights', such as political rights of representation and participation, civic rights of protection, 'duties vis-à-vis global institutions', as well as instruments of accountability and transparency. ${ }^{34}$ In short, global citizenship means the transfer of specific elements of national 
citizenship into the global domain so that specific global issues can be tackled.

On the basis of the previous synopsis, it is important to note that the cosmopolitan democracy thesis expresses itself as a postmodern reinterpretation of Kant's cosmopolitan philosophy. The focus on the institutional establishment of the cosmopolitan ideal and the emphasis on the multi-level nature of the emerging system of governance indicate that the thesis subscribes to the condition of multiple post-nationalism. The introduction of a (global) cosmopolitan citizenship status to complement national citizenship indicates that the project of cosmopolitan democracy aspires to comply with the de-national and the de-territorial, and consequently with the multiple conditions of citizenship. References to the continuing relevance of national as well as regional and local loci of citizenship in terms of social membership and collective identity in the globalised world mean that the thesis also claims to suit the requirements of multiculturalism. Finally, the expression of cosmopolitan citizenship as the empowerment of a nascent global civil society denotes the transnational ambition of the cosmopolitan democracy project.

\section{Cosmopolitanism and constitutional patriotism}

A comprehensive critique of the cosmopolitan democracy thesis is provided by Jürgen Habermas, whose own theorem shares a common foundation in universal ethics and rights. Like Held and Archibugi, Habermas endorses the requirement of supranational democratic institutions and transnational civic activity, and denies the viability of Kant's self-imposed limitations on political cosmopolitanism. Yet Haber- mas takes issue with the postmodern deficiencies and the traditional modernist premises of the Heldian model.

First, Habermas rejects the prospect of a world state that he claims underwrites the cosmopolitan democracy thesis. Habermas argues that Held's and Archibugi's cosmopolitan vision relies on the reproduction of state-like institutions on a global scale. Therefore its global community-building trajectory has a tendency to shift away from a multilayered post-national system of governance to a universal state. In particular, Habermas notes that the cosmopolitan democracy thesis explicitly advocates traditional institutions and guarantees of membership. Habermas instead envisions a new cosmopolitan order that is 'a dynamic picture of interferences and interactions between political processes that persist at national, international, and global levels'. 35 Further, Habermas proposes to introduce a procedural notion of governance, whereby only the conditions of rational and democratic decision making are guaranteed but not a fixed institutional and legislative outcome.

Second, Habermas also maintains that the thesis of cosmopolitan democracy does not employ multiculturalist attributes. It prioritises universalism that is focused on an all-inclusive and a priori sameness at the cost of multicultural particularism. It fails to engage with the notion of the 'other' in general and the idea of national political culture in particular. In simple terms, it cannot reconcile universalism and particularism and therefore re-establishes the competitive relationship between the national and cosmopolitan domains of collective belonging. 
On this point Habermas stresses the importance of implementing a new community-building logic in the national and the global domains. He argues that the cohesiveness of a national community cannot be guaranteed by fostering an exclusionary ethno-cultural identity. Instead, Habermas pleads for the advancement of a civic form of national identity: 'constitutional patriotism'. He reasons that rationally chosen commitments to a common set of constitutional principles, fundamental rights and democratic institutions can provide a common normative framework that is culturally neutral and therefore sufficiently inclusive for binding a multicultural society together. ${ }^{36}$

Habermas claims that although constitutional patriotism is posited on neutral and universally shared norms, it does not involve the rejection of particularism per se. Like any other civic form of collective identity, constitutional patriotism is also culturally patterned-it is an expression of 'universalism sensitive to difference'. 37 Universalism refers to the individuals' commitment to abstract principles and rights. Particularism is attributed to the context of a historically specific political culture', 38 which for Habermas is indeed crucial in translating abstract norms into meaningful political actions and institutions for the individual.

Habermas's third critique regards the democratic credentials of the cosmopolitan democracy thesis. He notes that Held et al. draw on the traditional Kantian belief in a pre-existing global morality that holds all humans together in a global community. This grounding implies that cosmopolitan rights are also understood as predefined and universal, distilled from the notion of global morality. ${ }^{39}$ For
Habermas, this logic is antithetical to the principles of democracy. Democracy, as Habermas understands it, is the selfdefined and self-legislated power of the public. That is, identity, rights and their institutional manifestations are organic and negotiated categories, and not elemental and constructed notions. The cosmopolitan democracy project does not meet this transnational requirement. Rather, it employs conservative notions of republican democracy and democratic legitimacy, relying on the logic of functional (or system) integration from above and avoids the notion of social, informal integration from below. In this sense, Habermas claims, the theory of cosmopolitan democracy subscribes to the traditional logic of community building that underlines the modern national paradigm of citizenship: citizenship rights constitute the single source of collective identity and collective identity is a sufficient source of legitimacy.

In order to overcome the democratic deficiency of the cosmopolitan democracy thesis, Habermas advocates the move away from representative towards a deliberative notion of democracy domestically and globally. The latter entails a more extensive involvement of the people in the political decision-making processes. ${ }^{40} \mathrm{It}$ involves a 'self-referential model of citizenship' 41 under an umbrella of a political order that is 'created by the people themselves and legitimated by their opinion and will formation'. ${ }^{42}$ In particular, deliberative democracy promotes channels of interactive and discourse-based civic activity in addition to the formalised institutional representation and participation of the citizen. ${ }^{43}$ It further facilitates a comprehensive notion of public sphere: a dimension of civil society whereby indi- 
viduals can engage in rational critical discourse about affairs of common political interests. Following from here, Habermas argues that deliberative democracy creates socially constructed collective identity that is constantly reproduced, and generates legitimacy from below. He notes that deliberative practices facilitate epistemic as well as integrative functions. They accumulate knowledge and thus enable reason-based decision making. They internalise decisions and create ownership of agreements. 44

Habermas's final criticism of the cosmopolitan democracy thesis refers to its empirical foundations. It is mistaken to base a cosmopolitanist thesis on the developments of the international domain: the evolution of an international human rights regime and the UN system. He insists that 'any plans for a "cosmopolitan democracy" will have to proceed according to another model $^{\prime} 45$ and posits the European Union as a viable 'example for a form of democracy beyond the nation-state'. ${ }^{46}$ Habermas points out that since Maastricht, the European Union has created and consolidated the status of union citizenship, gradually upgraded the European Parliament's decision-making power, introduced the deliberative-style convention method in the European Union's decision-making procedures and launched the constitutionalisation process. These developments, he argues, demonstrate the willingness of the political elites to empower the citizens of Europe in shaping the future direction of the integration project.

Despite this positive outlook, Habermas admits that the European Union is not yet adequately equipped to deliver on this promise. He insists that the integration venture must incorporate the vehicles of constitutional patriotism and deliberative democracy so that the deficiencies of the European Union's democratic capacity can be mended while the multi-layered nature of the European polity can be maintained. In particular, a common European political culture - shared political values, moral norms and legal rights - is yet to be distilled. The exercise of producing such a common ethical framework can only transcend but not erode national and cultural particularism if it wants to provide a viable and meaningful basis of solidarity for the public. ${ }^{47}$ For this, the European Union needs to advance the deliberative capacity of the supranational institutions of democracy, simplify multi-level decision making by deepening the federative aspects of the European Union ${ }^{48}$ and establish a common European constitution. ${ }^{49}$

\section{COSMOPOLITAN SHAPING OF THE EUROPEAN UNION'S CITIZENSHIP POLITY}

This section explores the rights attached to the union status, the way access to these rights is defined and the supranational institutional framework of these rights. The analysis is divided into three sections, which correspond to the European Union's constitutional development in the form of treaties. These are the founding treaties (1951, 1957), which established an embryonic supranational rights regime for Europe; the Maastricht Treaty (1992), which introduced the status of union citizenship; and the Treaty of Nice (2001), which launched the constitutional process in the European Union.

The founding treaties and Kantian cosmopolitanism 
Although it can be argued that European integration has always been a political project, the founding treaties did not contain explicit political provisions. These treaties focused on the functional, largely economic cooperation of the member states. Accordingly, the transfer of competencies and sovereignty from the national to the supranational level was minimal. The supranational decision-making mechanism and inter-institutional relationships were based on the primacy of national interests and the logic of intergovernmentalstyle bargaining. ${ }^{50}$ As a result, the sovereignty of the member states remained relatively intact. Thus, the creation of a common European status of citizenship in a binding treaty form was seen as neither viable nor desirable, and the founding treaties of European integration made no explicit reference to citizenship.

These treaties did, however, institute four basic freedoms in order to facilitate the establishment of a free trade area (later common market). These four freedoms pertained to the movement of goods, capital, services and, most importantly, persons/workers. These principles were later identified as 'mobility rights'. ${ }^{51}$ The ECSC Treaty (otherwise Treaty of Paris, 1951) applied the freedom of movement of people to only coal and steel workers, but the subsequent Rome Treaties (1957) extended the scope of mobility rights to all workers, with the only exception of those employed in the public service. ${ }^{52}$ In addition, these treaties also established a community-wide ethical framework for the European Union's emerging rights regime. They upheld the general principle of equality and introduced binding antidiscrimination legislation on grounds of nationality, race, ethnic origin, religion, gender and age.

Finally, the founding treaties also settled the institutional competences over these provisions. They empowered the High Authority (later European Commission) with the right to propose measures to achieve the free movement of workers. 53 It was, however, the member state that remained primarily responsible to decide on the content of mobility rights through the Council of Ministers, and then to implement them domestically. The third supranational institution, the Common Assembly-later to become the European Parliament (EP) — was a marginal supranational player at this time, which had an advisory role but no decision-making power. Its democratic credentials were also compromised as its members were appointed by national parliaments and not directly elected by the public. ${ }^{54}$ As a result, the developmental capacity of mobility rights remained in the hands of national governments.

The 'freedoms' of the founding treaties were, in effect, quite restricted. Due to the limited economic scope of community competences, the application of individual mobility rights, as well as the attached principles of non-discrimination and equality, was limited to employment in member states. The right of residency was granted only to workers and was linked to their right to exercise labour activity in another member state. ${ }^{55}$ Further, the member states were also granted the power to limit mobility rights on grounds of public policy, health and security. ${ }^{56}$ Finally, eligibility for European work permits was linked to 'recognised qualifications', as defined by national legislation. 57 These legislative and institutional re- 
strictions demonstrate that the early right provisions of EC treaties were not bound to any citizenship concept. They were pragmatic facilitators of the economic integration of the member states. In this sense, Elisabeth Meehan rightly points out that Europe's 'first citizens' were 'citizensas-workers, not citizens-as-human-beings' 58

Antje Wiener argues similarly when she stresses that the special rights granted to individuals by the founding treaties were not accessible for all Europeans but only for a well-defined group of community citizens. On this basis, she argues, these entitlements were inherently problematic as citizenship rights. Their limited scope and accessibility undermined the principle norms that underwrote the abstract notion of citizenship (and also cosmopolitanism), that of equality and individualism. Further to this, the restrictions also contradicted the principle of equality established in the very same treaties. 59

Therefore, I propose that Europe's rights regime created in the founding treaties conforms to the Kantian model of cosmopolitan citizenship. The very definition provided for mobility rights in the treaties echoes Kant's notion of cosmopolitan right - that is, the right to universal hospitality. The limited supranational character of European institutions in general and the restricted developmental capacity of the treaties' rights provisions in particular emulate the model of 'self-policing individual states', which underwrite Kant's cosmopolitan order.

\section{The Maastricht Treaty-cosmopolitan democracy?}

By the 1970s, the understanding of integration as a primarily economic cooperation of quasi-sovereign states driven by political elites changed profoundly. The deepening of the economic integration of member states, the multiplication of common policies and the extension of supranational competencies were shifting the scope of integration from economic to more political and social arenas. This transition culminated in the political redefinition of the European integration process, labelled as a paradigm shift from 'policy to polity' and from 'diplomacy to democracy'. ${ }^{60} \mathrm{~A}$ European polity was in the making.

The new discourse that stemmed from this transformation was organised around one key theme, that of legitimating the political development of the European project. The key question that engaged European political elites regarded the need for a European status of citizenship in order to render itself as a legitimate political community. 61

The Maastricht Treaty (1992) reflected the paradigm shift in constitutional terms. 62 In response to the desire for greater political legitimacy, it introduced the status of European Union citizenship - subsequently consolidated in the Treaty of Amsterdam (1997). Maastricht established that 'every person holding the nationality of a Member State shall be a citizen of the Union'. ${ }^{63}$ The status of union citizenship that emerged from Maastricht did not replace but complemented national citizenship. 64

There was a widespread view that the establishment of democratic institutions and legal status of European citizenship would solidify the European Union as an emerging political community and provide it with the direct popular legitimacy it lacked. ${ }^{65}$ The assumption that grounded this belief was a rather traditionalist take 
on the political uses of citizenship: rights translate into collective identity, and identity produces sufficient popular legitimacy. de Burca accordingly describes the concept of citizenship employed in the Maastricht era as 'unifying, communitybuilding, identity-building and legitimating'. 66

The Maastricht Treaty defined the status of union citizenship primarily as a legal concept, which contained a bundle of individual rights, specified access to these rights and set the institutional frameworks of the developmental capacity of the status. In addition, the treaty also reinforced the normative bedding of the European Union's rights regime. It explicitly linked the newly established status to earlier provisions, ${ }^{67}$ and incorporated the principles of non-discrimination, and the principle of equal access to the community's Civil Service. ${ }^{68}$

The rights of the union citizenship package, compared with what is generally regarded as citizenship, made up a rather limited and 'unusual' set of political and civil rights. ${ }^{69}$ Politically, the union status granted electoral rights: the rights to vote and stand in local government and European Parliament elections in the country of residence. This was limited to municipal (local) and European elections. They did not address state (national) and federal (regional) elections. ${ }^{70}$ Further to this, political freedoms - such as the freedoms of association, peaceful assembly and expression - were only implicitly referenced in EU law at the time of Maastricht. ${ }^{71}$ The Charter of Fundamental Rights was not incorporated in the treaty proper and therefore had only declaratory status in EU law. As such, the charter did not provide a binding framework of gen- eral principles for political membership in the European Union. ${ }^{72}$

With respect to civic rights, Maastricht granted the following entitlements: right to have diplomatic and consular protection from the authorities of any member state where the country of which a person was a national was not represented in a non-union country; right of petition to the European Parliament and appeal to the European Ombudsman. The Amsterdam Treaty later amended the civic component of the status to include the right to write to European institutions in any of the official EU languages and to expect a response in the same language. ${ }^{73}$ Amsterdam also introduced the transparency clause, making the documents of the parliament, the commission and the council accessible to union citizens, subject to certain principles and conditions. 74

Finally, as a clear indication of the will to generate a continuation of the preMaastricht legacy as well as to rationalise the so-called quasi citizenship rights established in the pre-Maastricht period, Maastricht also placed the so-called mobility rights under the union status. With this act, Maastricht extended the right to free movement in the member states' territory to all union citizens. ${ }^{75}$ The socalled attached rights - rights associated with the free movement principle, such as access to employment, welfare benefits and public services as well as passports, identity cards and resident permits - did not fall under supranational competences but were included within the intergovernmental decision-making mechanism. 76 This means that the content of and access to these rights were determined by national legislation. 77 
With regard to determining access to union citizenship rights, the Treaty of Amsterdam institutionalised the nationality rule. Only national citizens of the member states had access to union status and the rights it involved. 78 Thirdcountry nationals (TCNs) - nationals of non-European Union states-remained excluded from the political provisions of EU citizenship. This means that the Treaties of Maastricht and Amsterdam failed to establish a consistent legal basis for residency-based electoral rights: EU citizens had local voting rights throughout the union, while the granting of voting rights to TCNs remained dependent on national electoral legislation and diffuse international principles. ${ }^{79}$ The nationality rule was also applied to mobility and associated rights. The civic component of union citizenship was, however, conferred to all resident natural and legal persons.

The consolidation of supranational democracy was also an integral part of the legitimation efforts. Maastricht and Amsterdam set out to consolidate the institutional essentials of representative-style democracy. Direct elections based on universal suffrage to the European Parliament had been already effective since the Paris Summit resolution in 1974. The first such election took place in 1979. Until the Maastricht Treaty, however, the European Parliament was lacking effective political powers and was considered a secondary political player in the supranational edifice. Therefore, the specific objective of Maastricht and Amsterdam was to improve the relative political status of the parliament in the supranational decision-making edifice.

The TEU expanded the decision-making competences of the European Parlia- ment by the introduction of the co-decision procedure and the extension of the use of the cooperation and assent procedures. The co-decision principle gave the parliament the power in specific policy fields to adopt legislations jointly with the council. ${ }^{80}$ The extension of the cooperation and assent procedures established a greater consultative and mending role, and thus increased political influence for the European Parliament. As a result, the council was no longer in position to 'de facto impose its views on other institutions'. ${ }^{81}$

Nonetheless, the co-decision principle did not extend to all policy areas of common interest at that time; the power balance between the council and the parliament continued to favour national interests over European, and intergovernmental bargaining over supranational decision making. ${ }^{82}$ More notably, the overall strengthening of the European Parliament's formal power and relative status had little relevance for the European Union's common citizenship provisions. The co-decision principle did not apply to the policy field of citizenship. In matters of union citizenship, the European Parliament was granted only consultative competence. Maastricht specified that European citizenship rights could be amended via a truncated treaty amending procedure. The council would make the decision on strengthening or adding rights to the existing union status unanimously, on the basis of the commission's proposal and after consulting the parliament. ${ }^{83}$ As a result, the future potential of union citizenship lay clearly in the hands of the member states, and not the EU institutions or the newly established European public. 84 
On the basis of the above depiction of union citizenship in the Treaties of Maastricht and Amsterdam, it can be argued that the treaty approach to community building followed a similar logic to the cosmopolitan democracy thesis. Maastricht and Amsterdam focused on building the vertical relations between the citizen and the European polity. The 'national prototype' of citizenship was revoked on the supranational level as regards rights, access to rights and representative democracy beyond the State.

The implementation of Held's and Archibugi's cosmopolitanist ideal was, however, deficient in the European context. Instead of building a common status of citizenship that was independent of national citizenship, union citizenship was defined as a derivative and secondary status. The treaties also failed to assert the supranational competences over citizenship and the development of common citizenship remained under the control of the member states. The establishment of the European Parliament, and thus the European citizen, as a competent political actor was also lacking.

\section{Towards constitutional patriotism?}

The ratification crises in the 1990s were interpreted by many as an indication of the European Union's lingering legitimacy deficit. This was not interpreted as a sign of the public's rejection of the European integration project per se. According to the discourse of the Brussels elites, the causes of the crisis were specific and also rectifiable. The legitimacy crisis was interpreted as a combined failure of delivery and communication. Delivery referred to the failure to translate rhetorical promises and the public's primary concerns into concrete treaty provisions. At the time of Amsterdam, the economic phase of integration remained incomplete, the political provisions still embryonic and the common citizenship policy only a transitional arrangement. As for the last, the normative and the social (mobility rights) components were noted as seriously deficient. The communication failure was understood as the public's inability to connect with and understand the process, institutions and treaty provisions of European integration. Lack of sufficient information campaigns and the complexity of supranational structures and procedures were identified as the primary contributing factors.

The recognition of the complexity of the European Union's legitimacy deficit was linked to a growing awareness that the Maastricht approach to community building had failed. It became evident that conferring rights did not necessarily produce strong collective identification with political order. Although Maastricht can be considered a successful project in creating the legal hallmarks of citizen-polity relations, it failed in establishing citizen-citizen relations, instituting participatory channels of democracy and accommodating mediating structures. Without these, the formation of thick collective identities is problematic. The revision of the Maastricht approach also concluded that a (thin) collective identity was not a sufficient source of legitimacy. Maastricht and Amsterdam reinforced the traditional elite-driven nature of European integration, consolidated the dominance of intergovernmental decision making and instituted a rather deficient representative democratic body. This meant that the public had little if no influence on the shaping of the European polity, including 
the content of the European Union's common citizenship policy. In short, the Maastricht approach did not deliver on the putative need to generate a unified, active and enabled European demos.

The call for a new paradigm shift culminated in the commission's White Paper on Governance (2001). The white paper presented, once again, common citizenship as the cure for the European Union's legitimacy deficit. However, while the document defined similar long-term goals to the strategic underpinnings of the Maastricht and Amsterdam Treaties, it expressed profoundly different understandings of citizenship and legitimacy. Regarding citizenship, the white paper advocated a shift away from the politicolegal aspects towards the socio-cultural dimensions of citizenship. More notably, it proposed to complement the supranational arrangements of representative democracy with increased participatory opportunity channels. Improved participation would enhance the legitimacy and democratic credentials of European governance by transforming the 'top-down approach' of supranational decision making into 'more inclusive and accountable' processes. ${ }^{85}$

The white paper marked a conscious shift from the political to the social conditions of legitimacy. While Maastricht focused on building citizen-polity relations (vertical), the post-Maastricht narrative of the white paper concentrated on building citizen-citizen relations (horizontal). The proposal called for the establishment of deliberative frameworks of democracy. In particular, the introduction of the convention method was to facilitate a panEuropean dialogue, nurture a European civil society and ultimately produce a single legal basis, a constitution, for Europe - requisites of the emergence of a European demos. ${ }^{86}$

The white paper reflects a certain aspiration for provisions conducive to the establishment of a Habermasian-style constitutional patriotism. According to Habermas, pan-European solidarity and loyalty are to emanate from a set of legally entrenched rights and deliberative democratic procedures. Constitutional patriotism would ultimately establish the European citizen as not simply the subject but the creator of the EU law and the European polity. ${ }^{87}$

The post-Maastricht era brought about only a partial resolution of the deficiencies of the Maastricht approach and a limited implementation of the white paper's rhetorical promises. The Treaty of Nice and the Draft Constitution did not amend the rights component of union citizenship, and did not introduce new rights. Regarding political rights, they failed to extend the range of elections covered under the union status and did not establish a consistent constitutional legal basis for residency-based electoral rights. Neither did the Treaty of Nice and the Draft Constitution institute participatory and deliberative-style democracy in Europe. The treaties treated the notion of governance within the standard liberal model of representative democracy. Further, the relative status of the European Parliament has not been improved. Although there has been considerable increase in the use of qualified majority voting within the council, neither this nor the co-decision principle have been defined as the standard supranational decision-making mechanism.

The achievements of Nice and the Draft Constitution lie elsewhere. First, they 
made considerable progress in consolidating the normative framework of union citizenship. Fundamental rights were assembled in one single text, the Charter of Fundamental Rights of the European Union. The charter was proclaimed by all supranational institutions in Nice (2000) and later incorporated in the treaty establishing the Draft Constitution. Further to this, the protection of civil liberties of all individuals was reinforced. Second, Nice and the Draft Constitution also strengthened the supranational competences over mobility rights and attached rights. The treaties did not reform the overall supranational decision-making mechanism; the primary decision-making body remained the council. Nonetheless, according to the Nice resolutions, decisions regarding mobility rights were to be made according to qualified majority, and not unanimity, in the council. 88 Nice and the constitutional draft also moved considerable parts of the attached rights under supranational competences (EC pillar). Decisions about these attached rights were made according to the original restricted mechanism of decision making, that of the council's unanimous decision following consultation with the parliament. 89

That is, neither the Nice Treaty nor the failed Constitutional Draft Treaty implemented the Habermasian model of cosmopolitanism and established postmodern conditions for citizenship. The legal basis of union citizenship remained reliant on the premises of cosmopolitan democracy and tied to a traditional conceptualisation of citizenship.

\section{CONCLUSION}

The historical overview of the European Union's common citizenship policy demonstrates that the notion of union citizenship has followed the developmental arc of cosmopolitan thought. The understanding of common rights moved from the politically restrained grounds of Kantian cosmopolitanism to the HeldianArchibugian model of cosmopolitan democracy. By the time of the Draft Constitution, the European Union's citizenship discourse expressed Habermasian aspirations of establishing a new political community resting on the premises of constitutional democracy and a deliberative model of cosmopolitan citizenship. The rhetorical transition to the Habermasian model implies the European Union's ambition to overcome the traditional limitations of union citizenship and the shortcomings of its cosmopolitan credentials. It can be considered as a conscious move away from the national prototype to a postmodernist notion of citizenship.

Nonetheless, the translation of the rhetorical aspirations into concrete treaty provisions was insufficient, in terms of its cosmopolitan stance and postmodern potentials. As for its cosmopolitan credentials, union citizenship does not fully subscribe to the principles of universal egalitarianism. As political rights are not conferred on the basis of a Europe-wide residency rule, a considerable part of Europe's social constituency, TCNs, are excluded from the European Union's political process. TCNs are conferred only the civic entitlements of union citizenship. Further, due to the lack of supranational competences and common provisions to converge national citizenship policies, 
conditions for accessing national citizenship, and therefore the union status, are persistently diverse across the member states. This means that the European Union has also failed to establish a European norm of equality with regard to nationals as well.

From a postmodernist perspective, the shortcomings of the common citizenship policy - the nationality clause and partial constitutionalisation of the residency principle pertaining to voting rights; failure to include national elections in the electoral rights package; and consolidation of national competencies over supranational interests in the policy area of citizenship - all detract from the objective of creating a direct link between the individual and the union. Maastricht, rather, helped to consolidate national sovereignty $^{90}$ and established a subordinate supranational citizenship status. The postnational credentials of the European Union's common citizenship regime thus remained compromised.

The post-national multicultural qualities of union citizenship were limited by the consolidation of the nationality rule. The nationality rule undermined the cosmopolitan principles of generality and reinforced the national character of citizenship in Europe. Further, it prioritised national/ethno-cultural difference over other types of diversity.

Finally, the decision-making procedure specified in the treaties is problematic regarding the transnational value of common voting rights. Gardner remarks that electoral rights are the central 'hallmarks' of citizenship since 'the content of the rights and duties of citizens at any one time can indirectly be influenced or determined by its exercise'. ${ }^{91}$ Despite the rhetorical am- bitions, the treaties continue to facilitate representative, rather than participatory and deliberative, democracy. Therefore the European Union currently does not sufficiently facilitate its citizens' involvement in the shaping of the future direction of the integration project. Further, the competence to determine the very status of union citizenship is still not delegated to the European Parliament, thus allocating European citizens a minor role in the shaping of the European Union's evolving political community.

The two corollary conclusions that stem from these observations are the following. First, the legal and institutional foundations of union citizenship have failed to move away from the national prototype of citizenship. The treaties have not established the postmodernist credentials of political membership and collective belonging in Europe. The limited transnational and multicultural character undermines the legitimating potential of union citizenship. Second, the bifurcation of narrative and treaty feeds into a rhetorical overreach, which, in the retrospect of the failure to ratify the Draft Constitution and its subsequent revision, ${ }^{92}$ has contributed to the European Union's lingering legitimacy deficit. It can then be argued that the proto-cosmopolitanist posing of citizenship in Europe seriously undermines the integrative and legitimating potential of common citizenship in Europe.

On such critical grounds, I wish to put forward the following recommendation. By overcoming the postmodernist deficiencies of union citizenship, the European Union could translate its rhetorical promises into concrete political action, which in turn would close the union's legitimacy gap. In particular, in order to generate a 
culturally neutral and all-inclusive framework for accommodating all types of diversity, the European Union shall override the nationality clause and place political rights on a residency basis, and establish a European condition of residency. This would enhance the multicultural credentials of union citizenship and also emancipate it from national citizenship, making it of post-national status. Further to this, by the extension of the co-decision principle, the European Union could place the parliament on equal footing with the council. This, matched with residency-based electoral supranational rights, would found the transnational condition of $\mathrm{EU}$ democracy.

\section{ENDNOTES}

1 Thomas Pogge defines three central principles that all streams of cosmopolitan thought share: individualism, universality and generality. According to individualism and universality, cosmopolitan citizenship rights are granted to all human beings. These tenets also underwrite the modernist liberal paradigm of rights. It is the principle of generality that distinguishes cosmopolitanism from state-based citizenship. In opposition to the particularistic character of the national paradigm of rights, generality means that the cosmopolitan status has a global force. See Pogge, Thomas W. 1992, 'Cosmopolitanism and sovereignty', Ethics, vol. 103, no. 1.

2 The literature identifies three stages in globalisation studies. First-wave scholars investigated the impact of globalisation on national economies and concluded that a neo-liberal world economy government and homogenous world society were on the rise and the national state was in demise (globality and universalism). The second-wave engaged in the cultural aspects of globalisation and argued against the convergence thesis of the first wave. It advocated a fragmented and multidimensional world view, whereby national communities would be only one of the multiple loci of human organisation (globalism and particularism). The third-wave brings together a multidisciplinary and multidimensional exploration of globalisation, with particular focus on the political manifestation of globalisation. It concludes that globality and globalism represent the dual character of globalisation, in that they simultaneously generate the condi- tions of universalism and particularism. Beck, Ulrich 2000, What is globalization?, Polity Press, Malden, Mass.; Brodie, Janine 2004, 'Introduction: globalization and citizenship beyond the national state', Citizenship Studies, vol. 8, no. 4; Falk, Richard 2000, 'The decline of citizenship in an era of globalization', Citizenship Studies, vol. 4, no. 1.

3 Habermas, Jürgen 1996, 'The European nationstate - its achievements and its limits. On the past and future of sovereignty and citizenship', in Gopal Balakrishnan (ed.), Mapping the Nation, Verso, London; Habermas, Jürgen 2003, 'Making sense of the EU: toward a cosmopolitan Europe', Journal of Democracy, vol. 14, no. 4; Archibugi, Daniele, Held, David and Kohler, Martin (eds) 1998, Re-Imagining Political Community - Studies in cosmopolitan democracy, Stanford University Press, Stanford; Linklater, Andrew 2002, 'Cosmopolitan citizenship', in Engin F. Isin and Brian F. Turner (eds), Handbook of Citizenship Studies, Sage, London; Preuss, Ulrich 1998, 'Citizenship in the European Union: a paradigm for transnational democracy', in Archibugi et al., $R e$ Imagining Political Community; Rumford, Chris 2003, Rethinking the state and polity-building in the European Union: the sociology of globalization and the rise of reflexive government, European Political Communication Working Paper Series, Issue 4/03; Rumford, Chris 2003, 'European civil society or transnational social space?', European Journal of Social Theory, vol. 6, no. 1; Weiler, Joseph 1996, 'European neo-constitutionalism - in search of foundations for the European constitutional order', in Richard Bellamy and Dario Castiglione (eds), Constitutionalism in Transformation, Blackwell Publishers, Oxford.

4 Bowden, Brett 2003, 'The perils of global citizenship', Citizenship Studies, vol. 7, no. 3.

5 Chris Rumford expressly concludes: 'Modernity has come to an end, replaced by the Global Age, a transformation which requires a new conceptual framework.' See Rumford, Chris 2002, The European Union: A political sociology, Blackwell, Oxford, p. 24. See also Albrow, Martin 1996, The Global Age: State and society beyond modernity, Polity Press, Cambridge; Biswas, Shampa 2002, 'W(h)ither the nation-state? National and state identity in the face of fragmentation and globalisation', Global Society, vol. 16, no. 2; Brodie, Janine 2004, 'Introduction: globalization and citizenship beyond the national state', Citizenship Studies, vol. 8, no. 4 .

6 Nussbaum, Martha 1994, 'Patriotism and cosmopolitanism', Boston Review, vol. 19, no. 5, p. 5.

7 Habermas, 'The European nation state-its achievements and its limits'; Koopmans, Ruud and Statham, Paul 2000, 'Challenging the liberal nationstate? Post-nationalism, multiculturalism, and the collective claims-making of migrants and ethnic minorities in Britain and Germany', in Ruud Koop- 
mans and Paul Statham (eds), Challenging Immigration and Ethnic Relations Politics, Oxford University Press, Oxford.

8 Conway, Janet 2004, 'Citizenship in a time of empire: the world social forum as a new public space', Citizenship Studies, vol. 8, no. 4. See also Dagnino, Evelina 1998, 'Culture, citizenship and democracy: changing discourses and practices of the Latin American left', in Sonia E. Alvarez, Evelina Dagnino and Arturo Escobar (eds), Cultures of Politics, Politics of Cultures: Re-visioning Latin American social movements, Westview Press, Boulder, Colo.; Falk, Richard 1994, 'The making of global citizenship', in Bart van Steenbergen (ed.), The Condition of Citizenship, Sage, London; Falk, 'The decline of citizenship in an era of globalization'; Fraser, Nancy 1997, Justice Interruptus: Critical reflections on the 'postsocialist' condition, Routledge, New York.

9 Delanty, Gerard 2006, 'Nationalism and cosmopolitanism: the paradox of modernity', in Gerard Delanty and Krishan Kumar (eds), The SAGE Handbook of Nations and Nationalism, Sage, London; Linklater, 'Cosmopolitan citizenship'.

10 The depiction of Kant's cosmopolitan theory in this article relies primarily on Kant's highly influential 1795 essay, 'Perpetual peace'. His further works - such as 'Idea for a universal history with cosmopolitan purpose', 'The metaphysics of morals' and 'The conflict of faculties' - will also be referenced. See Kant, Immanuel 1970 [1795], 'Perpetual peace: a philosophical sketch', in Murray Forsyth, Maurice Keens-Soper and Peter Savigear (eds), The Theory of International Relations: Selected texts from Gentili to Treitschke, Allen \& Unwin, London; Kant, Immanuel 1970 [1784], 'Idea for a universal history with cosmopolitan purpose', in H Reiss (ed.), Kant's Political Writings, Cambridge University Press, Cambridge; Kant, Immanuel 1991, The Metaphysics of Morals, Translated by Mary J. Gregor, Cambridge University Press, Cambridge; Kant, Immanuel 1992, The Conflict of Faculties, Translated by Mary J. Gregor, University of Nebraska Press, Lincoln. Further, the article also presents a mainstream reading of Kant's cosmopolitan vision, which accepts Kant's self-imposed limitations on political/institutional cosmopolitanism and thus a world state. This orthodox reading is claimed to have grounded modern international relations theory and contemporary streams of cosmopolitan thought. Central to the mainstream reading of Kant's theory is the original scholarship of Friedrich and Hisley (see Friedrich, Carl Joachim 1948, Inevitable Peace, Harvard University Press, Cambridge, Mass.; Hinsley, F. H. 1963, Power and Pursuit of Peace: Theory and practice in the history of relations between states, Cambridge University Press, Cambridge). On non-orthodox reading, see further under Note 17.
11 Kant's 'Doctrine of rights' (6:34), cited in Muthu, Sankar 2000, 'Justice and foreigners: Kant's cosmopolitan rights', Constellations, vol. 7, no. 1, p. 32. See also Brown, Garrett Wallace 2005, 'State sovereignty, federation and Kantian cosmopolitanism', European Journal of International Relations, vol. 11, no. 4; Hutchings, Kimberly 1999, 'Political theory and cosmopolitan citizenship', in Kimberly Hutchings and Roland Dannreuther (eds), Cosmopolitan Citizenship, St Martin's Press, New York.

12 'Perpetual Peace', p. 107. See also Muthu, 'Justice and foreigners'.

13 Ibid., p. 105, emphasis added.

14 Brown, 'State sovereignty, federation and Kantian cosmopolitanism', p. 511. See also Pagden, Anthony 2000, 'Stoicism, cosmopolitanism, and the legacy of European imperialism', Constellations, vol. 7, no. 1.

15 'Perpetual Peace'; Brown, 'State sovereignty, federation and Kantian cosmopolitanism'; Covell, Charles 1998, Kant and the Law of Peace. A study in the philosophy of international law and international relations, Macmillan, London; Donaldson, Thomas 1992, 'Kant's global rationalism', in Terry Nardin and David Mapel (eds), Traditions of International Ethics, Cambridge University Press, Cambridge; Franck, Thomas M. 1990, The Power of Legitimacy Among Nations, Oxford University Press, Oxford; Linklater, 'Cosmopolitan citizenship'; Pagden, 'Stoicism, cosmopolitanism, and the legacy of European imperialism'.

16 A term borrowed from Linklater, 'Cosmopolitan citizenship', p. 321 .

17 Kant explicitly remarked that 'this federation does not aim to acquire any power like that of the state, but merely to preserve and secure the freedom of each state itself ('Idea for a universal history with cosmopolitan purpose', p. 104; 'Perpetual peace', p. 47). According to the mainstream interpretation of Kant's limited political cosmopolitanism, as presented in this article so far, Kant consolidated the centrality of the national state as the locus of political power and the referent to the political organisation of humanity. Nonetheless, there exists another, non-orthodox reading of Kant's scholarship. There are a number of scholars who argue that Kant's cosmopolitan vision is a teleological theorem and ultimately antagonistic to the modern state. The textual inconsistencies and ambiguities indicate that Kant proposed that the federative association of states was indeed a transitional stage towards a world republic. See Bull, Hedley 1977, The Anarchical Society: A study of order in world politics, Columbia University Press, New York; Cavallar, Georg 1999, Kant and the Theory and Practice of International Right, University of Wales Press, Cardiff; Bohman, James and Lutz-Bachmann, Matthias (eds), Perpetual Peace: Essays on Kant's 
cosmopolitan ideal, MIT Press, Cambridge, Mass.; Wight, Martin 1987, 'An anatomy of international thought', Review of International Studies, vol. 13, no. 3.

18 For Kant, the internal conditions of democracy meant the implementation of four principles: separation of powers; freedom for all members of society; legal equality of citizens; dependence of everyone upon a single common legislation. That is, liberal democracy and representative government are the essential and sufficient mechanisms to generate the internal guarantees of Kant's cosmopolitan ideal. Further, inherent to Kant's depiction of republican democracy was the establishment of a social contract (anima pacti orignarii) between the citizen and the State. With this, Kant expected to delegate sovereign power to the people and thus to replace the liberal idea of absolute sovereignty with the republican idea of popular sovereignty. For Kant, the long-term guarantee for the democratic credentials of the State rested on popular sovereignty (see 'Perpetual peace'). See also Franceschet, Antonio 2002, 'Popular sovereignty or cosmopolitan democracy? Liberalism, Kant and international reform', European Journal of International Relations, vol. 6, no. 2 .

${ }^{19}$ Brown, 'State sovereignty, federation and Kantian cosmopolitanism', p. 503.

20 'Perpetual peace', p. 210; 'Idea for a universal history', p. 49.

21 Kant wrote that the right to hospitality derived from the ancient and natural right to 'free access to all for the purpose' to 'establish community with all' ('Perpetual peace', pp. 107-8, 106-7).

22 Kant, Immanuel 2002, Critique of Practical Reason, Translated by Werner S. Pluhar, Hackett Publishing, Indianapolis, Ind., p. 321.

23 Delanty, 'Nationalism and cosmopolitanism'. Further to universalism and liberal nationalism, Delanty identifies a third stream of the contemporary cosmopolitan scholarship: post-colonialism. The postcolonial stream differs from universalism and liberal nationalism, in that it rejects the modernist legacy of political thought in general and opposes the Eurocentrism and liberal individualistic ideology entailed in the other streams of cosmopolitanism. Post-colonialists argue that the nation and national identity are essentially hybrid categories, in which the national, transnational and global domains are simultaneously implicated. That is, nationalism and cosmopolitanism are neither competing nor separable frameworks for the political and social organisation of humanity. For post-colonialism, see Bhabha, Homi K. (ed.) 2000, 'Cosmopolitanisms', Public Culture, vol. 12, no. 3; Bhabha, Homi K. 1990, Nation and Narration, Routledge, London; Appiah, Kwame Anthony 1998, 'Cosmopolitan patriots', in Pheng Cheah and Bruce
Robbins (eds), Cosmopolitics: Thinking and feeling beyond the nation, University of Minnesota Press, Minneapolis, Minn.

24 Miller, David 1999, 'Bounded citizenship', in Hutchings and Dannreuther, Cosmopolitan Citizenship; Miller, David 2000, Citizenship and National Identity, Polity Press, Oxford; Walzer, Michael 1994, 'Spheres of affection. In response to Martha Nussbaum's patriotism and cosmopolitanism, 1994', Boston Review, vol. 19, no. 5; Walzer, Michael 1997, On Toleration, Yale University Press, New Haven.

25 Linklater, 'Cosmopolitan citizenship', p. 328.

26 Held, David 1997, 'Democracy and globalization', Global Governance, vol. 3, no. 3, p. 225.

27 Archibugi, Daniele 1998, 'Principles of cosmopolitan democracy', in Archibugi et al., Re-Imagining Political Community, pp. 207-9. See also Archibugi, Daniele 2004, 'Cosmopolitan democracy and its critics: a review', European Journal of International Relations, vol. 10, no. 3 .

28 Archibugi, 'Principles of cosmopolitan democracy', pp. 210-11.

29 Held, 'Democracy and globalization', p. 263.

30 Archibugi, Daniele and Held, David (eds), Cosmopolitan Democracy - An agenda for a new world order, Polity Press, Oxford, p. 14.

31 Held, David 1995, Democracy and the Global Order-From the modern state to cosmopolitan governance, Polity Press, Oxford, p. 274 (emphasis added).

32 Archibugi, 'Cosmopolitan democracy and its critics', p. 456. See also Carter, April 2001, The Political Theory of Global Citizenship, Routledge, London; Dower, Nigel and Williams, John (eds) 2002, Global Citizenship - A critical introduction, Routledge, New York; Heater, David 2002, World Citizenship: Cosmopolitan thinking and its opponents, Continuum, London.

33 Archibugi, 'Cosmopolitan democracy and its critics', p. 456.

34 Archibugi, 'Principles of cosmopolitan democracy', pp. 216-17. See also Dower, Nigel 2000, 'The idea of global citizenship', Global Society, vol. 14, no. 4; Held, 'Democracy and the global order'; Linklater, 'Cosmopolitan citizenship'.

35 Habermas, Jürgen 2001, 'The postnational constellation: political essays', in Thomas McCarthy(ed.), Studies in Contemporary German Social Thought, Polity Press, Cambridge, p. 110.

36 Habermas, Jürgen 1994, 'Struggles for recognition in the democratic constitutional state', in Amy Guttman (ed.), Multiculturalism: Examining the politics of recognition, Princeton University Press, 
Jürgen. See also MacCormick, Neil 1999, ‘Does a nation need a state? Reflections on liberal nationalism', in Edward Moritimer (ed.), People, Nation and State: The meaning of ethnicity and nationalism, I. B. Tauris, London.

37 Habermas, 'The postnational constellation', p. 84.

38 Habermas, Jürgen 1998, 'The European nationstate: on the past and future of sovereignty and citizenship', Public Culture, vol. 10, no. 2, p. 226.

39 Habermas, 'The postnational constellation'. See also Fine, Robert and Smith, Will 2003, 'Jürgen Habermas' theory cosmopolitanism', Constellations, vol. 10, no. 4 .

40 Habermas, 'The postnational constellation'.

41 Ibid, p. 76 (emphasis added).

42 Ibid, p. 65. See also Habermas, Jürgen 1995, 'Citizenship and national identity: some reflections on the future of Europe', in Ronald Beiner (ed.), Theorizing Citizenship, University of New York Press, Albany.

43 Habermas, 'The European nation state-its achievements and its limits'. See also Cohen, Joshua 1989, 'Deliberation and democratic legitimacy', in Alan Hamlin and Phillip Pettit(eds), The Good Polity, Blackwell, Oxford; Dryzek, John S. 1990, Discursive Democracy, Cambridge University Press, Cambridge; Dryzek, John S. 2000, Deliberative Democracy and Beyond, Oxford University Press, Oxford.

44 Habermas, 'The postnational constellation', p. 76.

45 Habermas, Jürgen 2001, 'Why Europe needs a constitution', New Left Review, vol. NLR II, no. 11, p. 109.

46 Habermas, 'Making sense of the EU', p. 94.

47 Habermas, 'Citizenship and national identity'.

48 Habermas, 'Making sense of the EU'.

49 Habermas, Jürgen 1999, 'The European nationstate and the pressures of globalization', New Left Review, vol. NLR I, no. 235.

50 Nugent notes that the founding treaties put in place a mechanism of decision making in which 'the Commission would propose, the Parliament would advise, the Council would decide, and-when law was made - the Court of Justice would interpret'. See Nugent, Neill 2003, The Government and Politics of the European Union, Macmillan and Palgrave, Houndmills, Basingstoke and New York, p. 49.

51 Maas, Willem 2005, 'The genesis of European rights', Journal of Common Market Studies, vol. 43, no. 5. Further, the importance of mobility rights was acknowledged by Europe's political elites. The freedom of movement of workers was noted to 'represent a rather incipient form - still embryonic and imper- fect - of European citizenship' (Levi-Sandri, Lionello 1968, Free movement of workers in the European Community, Bulletin EC 11/68, Commission of the European Communities, Brussels, p. 6). See also Hallstein,Walter 1972 [1969], Europe in the Making, Allen \& Unwin, London.

52 The Rome Treaties defined the freedom of movement for workers as the right...to accept offers of employment actually made; to move freely within the territory of the Member States for this purpose; to stay in a Member State for the purpose of employment... [and] to remain in the territory of a Member State after having been employed in that State' (Treaty of Rome, EEC, Article 48).

53 Treaty of Rome, EEC, Article 49.

54 The fourth institution, the European Court of Justice (ECJ), was set up as a supranational legal body with the competence to produce binding legislation as regards community competencies. It was not until the late 1970s, by the time the European Court of Justice accumulated a vast amount of case law, that it started to play a greater role in the non-legal, political shaping of the European venture.

55 Treaty of Paris, Article 69; Treaty of Rome, Article 48. The ECSC Treaty announced that the 'Member States undertake to remove any restriction based on nationality upon the employment in the coal and steel industries of workers who are nationals of Member States and have recognised qualifications in a coalmining or steelmaking occupation, subject to the limitations imposed by the basic requirements of health and public policy' (Treaty of Paris, Article 69).

56 Maas, 'The genesis of European rights', pp. 1014, 1020-1. Maas remarks that since the introduction of the freedom principles, the legal and practical restraints on the freedom of movement have been gradually disappearing. Nevertheless, on the basis of Articles 39 and 46 in the Treaty of Amsterdam (1997), mobility rights continue to be subject to these limitations.

57 Treaty of Paris, Article 69.

58 Meehan, Elizabeth 1993, Citizenship and the European Community, Sage, London, p. 147. See also Everson, Michelle 1995, 'The legacy of the market citizen', in Jo Shaw and Gillian More (eds), New Legal Dynamics of European Union, Oxford University Press, Oxford.

59 Antje Wiener expressly writes that the set of rights granted to certain groups of citizens of the member states 'was not only contradicting the universalising (Europeanizing) mission of the integration of the founding fathers but also posed a challenge to conceptualisations of citizenship as universal'. Further, Wiener remarked that this intrinsic tension of 
the early approach to 'citizenship' rights was only, and only partially, resolved by the institutionalisation of the status of union citizenship in the Maastricht Treaty (Wiener, Antje 1998, European Citizenship Practice: Building institutions of a nonstate, Westview Press, Boulder, Colo., p. 294).

60 Shaw, Jo 1998, 'The interpretation of European Union citizenship', Modern Law Review, vol. 61, no. 3; Bellamy, Richard and Castiglione, Dario 1998, 'Between cosmopolis and community: three models of rights and democracy within the European Union', in Archibugi et al., Re-Imagining Political Community; Chryssochoou, Dimitris N. 2001, 'Paradigm shift: from policy to polity', in Dimitris N. Chryssochoou (ed.), Theorizing European Integration, Sage, London. 61 As testimony to the political awakening of Europe, the discourse about legitimacy produced a number of policy initiatives as regards common European citizenship, such as: the Tindemans Report (1975), the Dooge Report (1984), the Draft Treaty Establishing the European Union by the Spinelli group (1984) and the Adonnino Report (1985).

62 In the late 1980s, the decision-making elites of the European Community proved to have insufficient political commitment (council) and inadequate political weight (commission and parliament) to push through politically candid proposals. The Single European Act (SEA, 1987) did introduce common citizenship status and did not increase the status of the European Parliament.

63 Treaty on European Union (TEU), Article 8; Treaty of Amsterdam (hereafter, TEC), Article 17.

64 TEC, Article 17.

65 Jo Shaw writes that 'specific motivation for the institution of the concept of citizenship via the Treaty of Maastricht was a top-down [approach] concerned with facilitating the creation of European identity, and even a European demos which could be the basis for a European democracy'. See Shaw, Jo 2007, 'The transformation of citizenship in the European Union: electoral rights and the restructuring of political space', in Laurence Gormley and Jo Shaw (eds), Cambridge Studies in European Law and Policy, Cambridge University Press, Cambridge, p. 38.

66 de Burca, Grainne 1996, 'The quest for legitimacy in the European Union', Modern Law Review, vol. 59, no. 3, p. 359. de Burca (ibid., pp. 355-6) further elaborates: 'What most of the suggestions and proposals [had] in common [when preparing the Maastricht Treaty as well as in the post-Maastricht Treaty debates was] that the concept of European citizenship has the potential to contribute to a sense of European identity and thus of identification with the Union as a legitimate polity'.
67 These included: fundamental freedoms and the principle of equality as set out in the Rome Treaties (1957), the Joint Declaration on Fundamental Human Rights (1977), the Declaration on Democracy (1978), the principle of direct parliamentary elections (1979) and the Charter of Fundamental Social Rights (1989). 68 TEU, Articles 12-13.

69 TEU, Articles 8a-8d; TEC, Articles 18-21.

70 This is often considered an important limitation that renders the union status deficient and secondary to national citizenship. See Meehan, Citizenship and the European Community; O'Keefe, David 1994, 'Union citizenship', in David O'Keefe and Patrick M. Twomey (eds), Legal Issues of the Maastricht Treaty, Wiley, Chichester; d'Oliviera, Hans 1994, 'European citizenship: its meaning, its potential', in Renaud Dehousse (ed.), Europe After Maastricht: An ever closer union?, Law Books in Europe, Munich. Heather Lardy goes even further and contests whether the union citizenship status 'which carrie[d] with it such limited political rights [was] not really a form of citizenship at all'. See Lardy, Heather 1996, 'The political rights of union citizenship', European Public Law, vol. 2, no. 4, p. 613.

71 Article 12 in the Charter of Fundamental Rights addressed the freedom of association in political matters. In Article 21(2), the charter prohibited discrimination on grounds of nationality.

72 Shaw, 'The transformation of citizenship', p. 155. Further, Shaw notes that political freedoms are expressly provided to foreign residents on the same terms as to nationals of the given state in the Council of Europe's Convention on 'Participation of foreigners in public life at the local level'. However, as the convention was signed by only the minority of the community's member states, it could not provide a universal and binding legal basis for political freedoms in EU law either.

73 TEC, Articles 21 and 314.

74 TEC, Article 255.

75 It was argued that the inclusion of mobility rights in the union status resolved the tension between access to freedom principles and the universal conceptualisation of citizenship rights. It is important to emphasise that this was, however, only a partial resolution, as the union status remained inaccessible to third-country nationals under EU law; see nationality clause later. See Wiener, European Citizenship Practice.

76 These were included within 'Justice and Home Affairs' (otherwise, Third Pillar) in the Maastricht Treaty. For background, with the reinforced European Parliament, the Maastricht Treaty solidified a two-tier decision-making and legislative system for the European Union. This was based on the division 
of powers between the national and supranational levels. The novelty of Maastricht in terms of division of powers was a new pillar structure, which organised the competencies by policy fields. The first pillar concerned the domains in which the member states and the community had shared competencies and produced common policies under binding EU law. Decisions were taken according to the community method, favouring the co-decision and cooperation principles and the qualified majority rule in the council. The second pillar, titled Common Foreign and Security Policy (CFSP), established a mechanism for the member states to take joint actions, devise common strategies and reach common positions in the field of foreign policy. The second pillar followed an intergovernmental decision-making procedure that relied heavily on the unanimity rule in the council. The third pillar, titled Justice and Home Affairs (JHA), facilitated intergovernmental cooperation among the member states in the areas of freedom, security and justice. The TEU listed the following nine areas of 'common interest' under the JHA pillar: asylum; crossing of external borders; immigration; combatting drug addiction; combatting fraud on an international scale; judicial cooperation in civil matters; judicial cooperation in criminal matters; customs cooperation; police cooperation (TEU, Article 11; TEC, Article 29).

77 Previous treaties simply excluded these attached rights under the category of sensitive issues close to the concerns of national sovereignty (see TEC, Article 18[3]). Nonetheless, certain groups of TCNs had access to civic protection as well as mobility and attached social rights, originating in the resolutions of the Treaty of Rome, such as: members of a migrant EU family and nationals of a third country that held an agreement with the community. See Meehan, Elizabeth 2000, Citizenship and the European Union, ZEI Discussion Paper, C63/2000Meehan, Centre of Integration Studies, Rheinische Friedrich Wilhelms Universitat, Bonn; Shaw, 'The transformation of citizenship'.

78 TEC, Article 17.

79 Siofra O'Leary points out that by the implementation of the Maastricht Treaty, only three of the member states (Denmark, the Netherlands and Ireland) provided long-term residents with voting rights. As for international protocols, the electoral rights of immigrants in the member states remained dependent on the given state being a signatory of the Council of Europe's Convention on The Political Participation of Foreigners in Local Life (1992). See O'Leary, Siofra 1996, The Evolving Concept of Community Citizenship: From the free movement of persons to union citizenship, Kluwer Law International, The Hague. See also O'Keefe, 'Union citizenship'; Wiener, European Citizenship Practice.
80 Maastricht also improved the European Parliament's position vis-a-vis the European Commission. Parliamentary approval was henceforth required for the appointment of the Commission President (see TEU, Article 189b; TEC, Article 251).

81 Falkner, Gerda and Nentwhich, Michael 2000, 'The Amsterdam Treaty: the blueprint for the future institutional balance', in Karlheinz Neunreither and Antje Wiener (eds), European Integration After Amsterdam. Institutional dynamics and prospects for democracy, Oxford University Press, Oxford.

82 Ibid.

83 TEU, Article 8e; TEC Article 22.

84 Shaw, 'The transformation of citizenship', p. 9. See also Preuss, Ulrich, Everson, Michelle, KoenigArchibugi, Mathias and Lefebvre, Edwige 2003, 'Traditions of citizenship in the European Union', Citizenship Studies, vol. 7, no. 1.

85 European Commission, White Paper on European Governance, CONM 20010 428, The European Commission, Brussels .

86 The central objective of the white paper was identifying tools to improve the democratic capacity of the European Union. It argued for the introduction of participatory and deliberative opportunity channels to complement the supranational institution of representation. This was matched with a range of pragmatic reform proposals that aimed at closing the communication gap and providing a point of closure for the Maastricht initiatives. These included launching information campaigns and streamlining and simplifying the common policies and structures under a consolidated single treaty (constitution).

87 Habermas, 'The European nation-state: on the past and future'.

88 Constitutional Treaty (CT), Article III-125(1).

89 CT, Article III-125(2).

90 O'Leary, The Evolving Concept of Community Citizenship.

91 Gardner,J. P. 1997, Citizenship: The white paper, The Institute for Citizenship, London, p. 39.

92 Treaty of Lisbon (otherwise Reform Treaty), 2007. 



\title{
CITIZENSHIP AND IDENTITY IN DIVERSE SOCIETIES
}

\author{
MARK NOLAN AND KIM RUBENSTEIN
}

This article examines the relationship between the legal status of citizenship and psychological research about blended identity in diverse societies such as Australia. A blended identity could include Australian national identity as well as other identities relevant to a person's selfdefinition. Analysing the link between citizenship law and the psychological enjoyment of blended identity is important after the reforms to Australian citizenship law in 2007. ${ }^{1}$ As discussed below, the former Liberal-National Government introduced a new citizenship knowledge test for citizenship-by-conferral applicants. In doing so, that government expressed strong beliefs about the power of a shared, unitary, national identity. It also supported calls for citizenship applicants to sign a statement of Australian values (different to the citizenship pledge) and to complete an English language test. In light of the reforms and political debate, we attack the suggestion that blended identification (for example, as a Greek Australian) is somehow inconsistent with true Australian national identification and citizenship, and moreover we argue that a single national identification sits uneasily with the legal acceptance of dual or multiple citizenship in current Australian legislation.

We first discuss the concept of blended identity from a social-psychological perspective. Then we examine the details of the 2007 Australian citizenship law reforms, bearing in mind that the Rudd Labor Government recently released the report of the independent committee reviewing the Australian Citizenship Test and the government response to the report. $^{2}$

Legal notions of citizenship and the psychological experience of blended identities can often be in tension. This is understandable since legal and psychological concepts of national identity are but two ways of conceptualising relevant selfdefinitions shaping social existence and belonging in diverse societies. We do not believe that the legal identity or citizenship always completely defines the self in practice. However, we argue, as do other researchers, ${ }^{3}$ that citizenship law and psychological identity are in a relationship of mutual influence creating expectations about and reactions to legal treatment.

Notions of citizenship and associated assumptions about psychological identification that are legally endorsed in diverse societies have the power to legitimise as well as de-legitimise the desired enjoyment of self. Indeed, salient identities shape the perspective from which many people will either support or challenge citizenship law and decision-making processes. The extent to which the 2007 Australian reforms may have (de-)legitimised desired self-defini- 
tions will be examined in the final section of this article. Another way of addressing this issue is to consider whether citizenship law and application processing satisfy the basic human need for inclusion and for adequately expressing and enjoying all aspects of a blended identity. ${ }^{4}$

\section{PSYCHOLOGICAL-SOCIAL IDENTIFICATION}

This section begins by describing a process-based understanding of social identification. For example, an unsuccessful citizenship application results in particular self-definitions. So too could the existence of an official policy that treats different classes of citizens in different ways, such as testing only civics knowledge, values and language skills for particular citizen applicants and not, say, for Australians who are citizens by birth.

These situations can make a single identity salient and relevant for selfdefinition. However, sometimes such contexts can make a more complex blended social identity salient. For example, an instance of discrimination against Arab Australians could be relevant for their selfdefinition when reacting to felt discrimination. For example, this inter-group discrimination could result when an intelligence-gathering or policing decision is based on the assumption that one aspect of a person's identity (for example, their country of birth and/or religion) threatens national security by weakening their allegiance to Australia in some way. These assumptions and comparisons cause people to self-select identity or identities. However, context and comparisons can also cause people to be treated by others in terms of an identity even when they do not wish to so identify.

Both of these identity processes - selfdefinition and ascription of identity by others - narrow the number of identities used for self-definition. They render other aspects of self (for example, other identities based on, say, religion, gender, race, residence or political orientation) less relevant for shaping the immediate perspective from which people make social judgments, decisions or policies. This selection of relevant (or 'salient') identity by the social context has been demonstrated primarily by research focusing on changing operative social comparisons, but also by the nature of the normative content or ideologies related to salient identities. ${ }^{5}$

These contextual changes create identity management challenges for the social perceiver, helping them determine the psychologically best way to self-define or to respond to an (often unwanted) ascription of identity by another. Extending these process-based theories of singleidentity salience to the study of the simultaneous salience of many aspects or dimensions of self-definition ${ }^{6}$ constituting one blended identity is important for understanding citizenship and identity in diverse societies.

\section{BLENDED IDENTIFICATION AND ITS PSYCHOLOGICAL CONSEQUENCES}

\section{The concept of blended identity}

This article uses the term 'blended identity' to convey the concept that many different aspects or dimensions of self-definition can be salient simultaneously. In other words, it includes the situation where more than one identity simultan- 
eously shapes a person's self-definition in a particular social context. The study of blended identity is controversial, perhaps mainly due to the fact that some critics believe that this theoretical notion can be overstated. Some scholars reject talk of blended identity as naïve or unrealistic, concerned that some theorists suggest that the adoption of a blended identification is virtually automatic, common and universally desired. ${ }^{7}$ Of course, some migrants may wish to stop identifying in terms of an identity that, for example, represents a tyrannical regime from which they have escaped. Other critics of the notion of blended identity suggest that claiming that blended identification is common is simply another form of essentialism that suggests that migrants always identify in terms of these complex identities. This universalism is overstated in our view, and fails to explain the psychological processes determining when particular identifications occur. ${ }^{8}$ Our use of this concept, alongside empirical, process-based descriptions of blended identity salience, should reassure those critics.

The concept of blended identity has been discussed by researchers from a number of different disciplines. Other common terms include: dual nationality, dual citizenship, ethnic national identity, 9 hyphenated identity or ethnicity, ${ }^{10}$ or simply mixed identities. In particular, social psychologists have sometimes labelled blended identities as 'crossed categorisations' to describe the combination or 'crossing' of many identities to form a complex identity. There have been three decades of social psychological research into phenomena flowing from blended identifications. This has mainly involved research into how crossed categorisations shape perceptions of other group members. For example, being biased in favour of your in-group (that is, the identity perspective made salient for you by a social comparison) and distinguishing self from and/or thinking negatively of out-groups (that is, groups and their perspectives with which you do not feel a sense of belonging in the context of a particular social controversy). ${ }^{11}$

The term 'crossed categorisation' reflects theoretical ideas about social identity salience described above. In the case of blended identity salience, the social context makes salient at least two identities, rather than simply one identity. This more complex categorisation or definition of the self is the perspective from which people determine their identity-based beliefs and ideologies. 12 Importantly, researchers study crossed categorisations that include the salience of national identities as part of a blended identification. ${ }^{13}$

If people have many constituent aspects of self, it should not be surprising that sometimes two or more of these identities are simultaneously salient and responsible for shaping our perspective on a social issue. Perhaps these more complex, blended identities are in fact more normal for some people including migrants than is the simpler case of the salience of only one (national) identity. The burgeoning interest in the social psychology of crossed categorisations is a valuable addition to citizenship research. It is useful to consult research on crossed categorisation before citizenship law reform championing identification with only one single national identity is thought superior to celebrating blended identity. 


\section{Measurement of identification with a blended identity}

Verkuyten studied the relative strength of religious and national identification in a sample of 206 Turkish-Dutch citizens who identified as Sunni Muslims. Attitudes, though not real behaviours, towards other religious groups in the Netherlands were also measured. The study was conducted in the context of what Verkuyten describes as Dutch citizenship policies promoting assimilation via strong national identification. ${ }^{14}$

Verkuyten found that half of the sample rated their Islamic identity as strongly as they could on all measurement dimensions, choosing seven on a sevenpoint rating scale on all measures of the importance of the Islamic identity. This ceiling effect or 'total' identification as a Muslim within these blended identities was interpreted as supporting studies showing the very high importance of Islamic identity for Muslims living blended identities in the West. ${ }^{15}$

For these 'total' Muslim identifiers, the religious component of identity appeared a highly central way of defining self in the social judgment contexts examined. Importantly, even though half of the participants had a 'Muslim identity [that] was an integral or inextricable part of how they saw themselves', 16 their Dutch national identification was not eliminated. Their Dutch national identification was significantly lower than the national identification of the other half of participants whose Islamic identity was strong though not 'total'. Those with 'total' identification rated their in-group most positively and felt strongly about Islamic group rights. However, Verkuyten could still classify 19 per cent of the 'total' Muslim identifiers as high Dutch identifiers (who rated the importance of that identity above the midpoint of the response scale). Also, 31 per cent of high Muslim identifiers simultaneously identified as Dutch nationals and had high levels of national identification.

For some, the impact of strong religious identification upon national identification could appear alarming. However, the observable psychological benefits of these blended identities are an important part of evaluating any alleged risk of blended identification. For these 'totally identified' Muslim participants, the most negative feelings towards other religious groups in the Netherlands were towards non-believers. When total Muslim identification and high national identification co-occurred, hostility towards other religious groups (Jews, Christians, Hindus) decreased. Most negative beliefs about other Dutch religious groups were held by total Muslim identifiers with low national identification, suggesting that hostile beliefs were caused more by a single rather than a blended identification.

These data suggest the importance of relationships between each aspect of a blended identity for resulting social attitudes (that is, beliefs about nationality and about religious groups to which the perceiver does or does not belong). It does not suggest, however, that high or total identification as a Muslim always eliminates or suppresses national identification. This detail of this study is highlighted as an example of the type of research that should be conducted and consulted in order to understand the subtle dynamism of blended identity expression in political contexts. The reasons why a blended identifier does or does not strongly 
identify as a national of their country of residence is an important social-psychological and political question. Not only do these data suggest the reality of blended identities and the possibility of identification with a blended identity and high national identification, these data suggest that detailed measurement of the impact of citizenship regimes is needed so we can better understand exactly how and when citizenship regimes may stifle blended identities or allow them to exist.

Verkuyten notes too that crossing religious identity with national identity is an example of a complex blended identity, perhaps even more complex than combining two national identities or, say, language groups. ${ }^{17}$ It should be remembered that each example of crossed categorisation, in political and historical context, will produce its own unique identity management challenges. Possible social tensions that result are not simply a function of whether blended rather than single identity salience occurs but are influenced by relationships between the constituent identities in a crossed categorisation and social treatment of these identities.

\section{Common in-group identity research}

Some social psychologists argue that adopting one superordinate, common in-group identity (for example, Australian) within diverse societies can reduce tension and hostile beliefs between groups. However, some researchers have found this occurs when valued cultural identities (for example, Arab identity) can remain strong following identification with the common in-group identity (for example, Australian). 18 This suggests the benefit of blended identification that prevents mere recategorisation of all subordinate identities into a higher-order national identity. Rather than replacing this diversity with a unitary national identity, there is benefit in promoting a superordinate Australian citizenship that allows explicit and continuing identification with other elements of a blended identity.

Similarly, important recent empirical work reveals the impact on in-group bias when making a common in-group identity salient whilst measuring how people perceive the relative importance of maintaining a crossed categorisation. ${ }^{19}$ In this work, the perceived importance of the crossed categorisations determined whether use of a common in-group identity (for example, Australian) resulted in harmony and perceived inclusiveness instead of continuing tension and continuing perceptions of inter-group difference. Results showed that when the elements of a blended identity remained subjectively important for a perceiver, then identifying only in terms of a common in-group identity did not reduce perceived inter-group tension between subordinate identities.

\section{SOCIAL RESEARCH ON BLENDED NATIONAL IDENTITY}

In this section, social research on blended identity provides further examples of blended identification. Two examples are drawn upon: British Muslims and citizenship, as well as studies of Latin Australians.

\section{British Muslims and citizenship}

In line with other theorists, ${ }^{20}$ social psychologists Hopkins et al. suggest that sensitivity to cultural diversity has also created a tension between the actuality of a plurality of social identities and the 
singular identity implied by citizenship'. 21 In terms of self-categorisation theory, 22 these researchers analysed how British Muslims used Islamic identity to encourage or dissuade citizens voting during the 1997 general election. The British National Party (BNP) claimed that there was a contradiction between being a Muslim and being a British citizen. Against this political backdrop, the Muslim Parliament of Great Britain asked British Muslims to boycott the polls and to demand alternative institutional arrangements through which they could express their political views. ${ }^{23}$ They also claimed a degree of identity incompatibility, stating that British Muslims could not be loyal to the Labour Party and God at the same time. ${ }^{24}$ The Muslim Parliament called for British Muslims to live up to the example of the Prophet and to aim for interaction with the community without integration in Britain.

To counter that call, the UK Action Committee on Islamic Affairs cited Qur'anic verse to produce an anti-boycott message encouraging British Muslims to vote in order to fulfil the duty they owed to Britain. This civic duty as British citizens was asserted to be the same type of outward-looking, communal duty they owed as Muslims to other Muslims.

This political debate is a dramatic example of how blended identity can be used for political purposes in a dispute over citizenship rights (voting and representative democracy). It demonstrates that blended identity allows for the possibility of encouraging, as well as sometimes dissuading, civic participation when using rhetoric derived from all the aspects of a blended identity. Hopkins et al. state there is little use concluding that blended iden- tities will always have negative effects for national politics and harmony. The researchers note that conceptualising subjective notions of citizenship or blended British Muslim identity as fixed, essentialistic, homogenous or universally expressed concepts is misguided. Even if the BNP believed there was only one essential type of British Muslim, analysis of the real political context showed that there could be at least two British Muslim views on the importance of voting in the general election, both derived from Islamic texts. The ideological content of blended identifications and descriptions of citizenship will vary in line with specific political context and the political end sought, as may the case when single category national identities are used for political purposes. ${ }^{25}$

This dynamism should not be perceived as a weakness of blended identification per se. It is not as if all blended identities have an essence tending towards inevitable identity conflict. Rather, the social constructions revealed in this study reflected strategic political behaviour from a salient identity perspective. It demonstrates that each element of blended identification can be mutually reinforcing, as much as they can be antagonistic. In this sense, the research shows that one group of highly identified British Muslims sought political autonomy that downplayed the significance of British citizenship rights. The other, a similarly highly identified group of British Muslims, argued for election voting and full civic participation as a core duty consistent with their Muslim identity. The latter political approach demonstrated an ability to unify both aspects of their crossed categorisation despite political attack suggesting that a single British citizenship must prevail as 
it was inconsistent with blended identification as a British Muslim.

\section{Identification by Latin Australians}

Zevallos conducted a study of 13 young (seventeen to twenty-five year old) women of Latin American heritage living in Australia. ${ }^{26}$ Five of the participants were Australian born, and the remaining eight had come to Australia between the ages of two and seven. One finding obtained was that 11 of the 13 interviewees rejected the notion that their identities were best captured by the simple label 'Australian'; only two interviewees were happy with that label, having grown up in Australia.

This rejection of the singular label Australian did not mean they rarely felt Australian, or had low attachment to Australia. Indeed, they felt most Australian, and were treated most as Australians, when travelling in Latin American countries. ${ }^{27}$ When this salience occurred, they readily attributed traits, views and behaviours to their 'Australian side' or to the Australian influence upon their selfdefinition as, say, 'a South American living in Australia'. When discussing gender and sexuality issues, for example, the women endorsed values of egalitarianism as an Australian influence. In terms of the citizenship values debate in Australia, it is noteworthy that use of a blended identity does not mean these interviewees failed to endorse values (for example, egalitarianism) that some would claim as Australian.

Most of the women reported that Australia was considered to be home and where they hoped to have careers and children; interviewees contemplated only holidays in Latin American countries. However, they still preferred not to be defined simply as Australian. Based on the data collected, Zevallos concluded that: 'There has been no consensus on the best way to bridge the gap between the ideology of multiculturalism and an all-encompassing Australian identity.' 28

Perhaps the missing consensus on the best way to bridge the gap between the ideology of multiculturalism and an allencompassing Australian identity is to truly celebrate the existence of blended identities socially, politically and legally. Indeed, Australian citizenship law has moved from a rejection of dual or multiple citizenships to an acceptance and affirmation of these in legislation, to which this article now turns.

\section{AUSTRALIAN CITIZENSHIP LAW}

\section{Dual or multiple citizenship in Aus- tralia}

From the inception of the Australian Citizenship Act 1948 (Commonwealth) until 4 April 2002, there was a provision mandating loss of Australian citizenship for a person who acquired a new citizenship. This was found in Section 17 of the act ('Loss of citizenship on acquisition of another nationality'). ${ }^{29}$

Section 17 and the deterrence of dual citizenship was one of the most contested and contentious areas of the Australian Citizenship Act 1948 (Cth). Dual citizenship was the subject of a 1976 review by the Joint Committee on Foreign Affairs and Defence and it was also considered in the context of the national consultations on multiculturalism and citizenship conducted in 1982. Then, two further reviews considered the worthiness of s. 17, 30 and a related parliamentary review of s. 44(i), which disqualified dual citizens from be- 
coming Members of Parliament, also considered related policy matters. ${ }^{31}$

At one level there was a basic inequality in the system. When citizens of another country became Australian citizens, the approach in practice had varied. The pledge taken upon becoming an Australian citizen has changed over the years. Between 1966 and 1986 the words included 'renouncing all other allegiance'. ${ }^{32}$

However, this wording had no legal consequence for their status as citizens of the other country. As a matter of international law, it is a question for the country which bestows citizenship to determine whether someone loses that citizenship - it is an incident of sovereignty of that nation-state. The leading case on the question of nationality for the purpose of diplomatic protection is the 1955 Nottebohm case. $^{33}$

The High Court of Australia confirmed this in Sykes v. Cleary, 34 in which two of the people running for Parliament, and whose positions were challenged, were citizens of other countries, Greece and Switzerland, and therefore ineligible under s. 44(i) of the Australian Constitution.

The issue of dual citizenship became quite central to the deliberations of the Australian Citizenship Council. In August 1998, the Howard Government established the council as an independent body to advise it on Australian citizenship matters. In a report at the end of 1999, later published as Australian Citizenship for a New Century, the council made 64 recommendations including the repeal of Section 17. Considering matters such as globalisation, the Australian Citizenship Council stated:

[A]s we move into the twenty-first century, the prevalence of dual citizenship internationally will rapidly increase. The law and practice of most countries with which Australia likes to compare itself permits citizens of those countries to obtain another citizenship without losing their original citizenship...These countries simply recognize that they have an internationally mobile population and that they can retain connection with this population even if another citizenship is acquired. $^{35}$

This recommendation was acted upon by the government and implemented in the 2002 amendments to the act, which were then enhanced by the 2007 reforms to which discussion now turns.

\section{Howard Government policy reforms in 2007}

In 2007, the Howard Government introduced two separate pieces of legislation on citizenship that had different policy objectives. The first was the repeal of the 1948 statute with a new Australian Citizenship Act 2007. The second (and after the first was fully implemented) was an amendment to the new act introducing more elaborate citizenship testing.

\section{The 2007 act}

The Australian Citizenship Act 2007 came into force on 1 July 2007. As the Reader's Guide to the new act outlines, 36 the origins of the 2007 act lie with the former Australian Citizenship Council (the council). In its report at the end of 1999, referred to above, within its 64 recommendations was 'Refining the structure of the Australian Citizenship Act 1948'. 37 The 2007 act's origins lie with that recommendation. 
While all the other substantive changes to the 1948 act recommended in the council's report (such as the repeal of Section 17 of the former act to allow for dual citizenship) were implemented in legislation in 2002, this last recommendation to 'tidy up' the act 'to improve presentation so it is logically organized, numbered and consistent, with relevant matters dealt with together, and ensuring the balance of matters dealt with between the Act and the Regulations conforms to modern standards' was implemented with the passage of the Australian Citizenship Act 2007 (the new act).

The act has a more logical structure, including terminology that is more accessible and changes complementing the policy rationale of the 2002 amendments, as well as some further changes to assist Australia in better responding to the threat of terrorism. 38

The most significant change from the perspective of this article emanating from the report was the 2002 repeal of s. 17 of the original citizenship act. The new 2007 act extended that inclusive approach to Australian citizenship in various ways, including broadening the resumption of citizenship provisions and the extension of citizenship by descent to children of people who had lost their Australian citizenship.

These latter changes were part of the package that could be referred to as inclusive; they were including in the Australian community many people who had often seen themselves as Australians, but had not been recognised formally in law as such, and importantly for our discussion of blended identity, included dual citizens in the fullest legal sense. However, very soon after the passage of the new legisla- tion, an amendment act, which was introduced before the core legislation, was passed, ${ }^{39}$ underpinned by a less inclusive policy approach to Australian citizenship, as set out below.

\section{Citizenship testing}

Before the 2007 citizenship test reforms, citizen-by-conferral applicants generally had their language ability assessed at interview, though there was no standardised or objective test of English language proficiency. ${ }^{40}$ There was no formal written citizenship knowledge test administered, save for applicants needing to demonstrate at interview a satisfactory understanding of the rights and responsibilities of Australian citizenship. Citizenship applicants then needed to make the Citizenship Pledge (see below).

Following the passage of the Australian Citizenship Amendment (Citizenship Testing) Bill 2007, the minister can require certain applicants to sit a formal citizenship test (which may include English language testing as well as civics knowledge testing). ${ }^{41}$ A review of the amendment act is thoroughly canvassed in the Parliamentary Bills Digest. ${ }^{42}$ As part of the new administrative system, a resource book is available for prospective applicants to read, ${ }^{43}$ and from which information is available that will assist applicants in answering the randomly selected questions drawn from a secret set.

The department publishes Citizenship Test Snapshot Reports on a regular basis. ${ }^{44}$ The latest information about the testing reveals some form of substantive discrimination against test applicants from the humanitarian migration stream. The reporting from the Department of Immigration and Citizenship indicates that between 1 
October 2007 and 30 June 2008, 48713 individuals sat the citizenship test and 46 500 (or 95.5 per cent) passed it on their first or subsequent attempt. ${ }^{45}$ The pass rate (on first or subsequent attempt) for applicants who came to Australia under the Skilled Stream of the Migration Program was 99 per cent compared with 92 per cent for those who came under the Family Stream and 82 per cent for those applicants who came under the Humanitarian Program. Also, the average number of tests needed to be taken before passing per applicant appears greater for humanitarian (1.8) compared with family (1.3) and skilled migrant (1.1) applicants. The number of test applicants from each migration stream is as follows: skilled (48 per cent), family (22.2 per cent) and humanitarian (11.3 per cent).

\section{THE IMPACT OF AUSTRALIAN CITIZENSHIP LAW REFORM ON BLENDED NATIONAL IDENTITY}

Below, two possible results of inappropriate treatment of blended identities are considered: 1) increased identification following threat to one (national) identity; and 2) variations in identity attachment. The concept of honourable citizenship ${ }^{46}$ is also discussed below as a guide to how some migrants may wish their blended identity to be respected: needing their country of origin to be acknowledged and respected, rather than demonised or treated as if it is no longer psychologically significant. This section of the article considers whether the Howard Government's citizenship reforms and policies widen rather than bridge the gap between citizenship law and healthy psychological enjoy- ment of blended identity in diverse societies.

A single Australian identity: is keeping it simple stupid?

In the citizenship testing discussion paper, the Howard Government defined the desired normative content of an Australian identity:

Citizenship provides an opportunity for people to maximise their participation in society and to make a commitment to Australia's common values - which include the respect for the freedom and dignity of the individual, our support for democracy, our commitment to the rule of law, our commitment to the equality of men and women and the spirit of a fair go, or mutual respect and compassion to those in need. ${ }^{47}$

These values are similar though much more detailed and, perhaps, ideologically driven than the current citizenship pledge, which reads: 'From this time forward [under God], ${ }^{48}$ I pledge my loyalty to Australia and its people, whose democratic beliefs I share, whose rights and liberties I respect, and whose laws I will uphold and obey. 49

Zevallos cites Kukathas' warning that conflict is likely when culturally pluralistic societies such as Australia attempt to endorse a strong sense of national identity via reshaping of Australian institutions (including citizenship law) with the aim of further defining what it means to be an Australian. ${ }^{50}$ In light of these warnings, the most troubling aspect of the Howard Government's rhetoric surrounding its 2007 citizenship reforms was the official endorsement of citizenship as the celebra- 
tion of a simple, single national identity and as the best solution to inter-group tension or personal maladjustment. As attractive and consensual as this focus may at first appear, it asserts equivalence between a single citizenship identity and real psychological identification that may not exist in all cases. The government's preferred approach in 2007 was to encourage use of a single 'superordinate identity' to all new Australian citizens irrespective of their migration history and the extent to which a blended identity was important to them.

Instead of suggesting that true celebration of blended identity could create stability in a diverse society, the Howard Government's Discussion Paper on citizenship testing suggested that sustainable unity came via a simple, single national identity: 'Australian Citizenship is the single most unifying force in our culturally diverse nation. It lies at the heart of our national identity - giving us a strong sense of who we are and our place in the world. ${ }^{51}$

Unlike our thesis - that true recognition of blended identity may sometimes reduce social tension - the official endorsement of citizenship in 2007 was linked simply to identification as Australian; suggesting that diversity and harmony was strengthened rather than weakened by emphasising one Australian national identity in all contexts and in response to all social comparisons within Australia. Testing English language proficiency, Australian civics knowledge and asking applicants for an endorsement of Australian values were tools thought by the Howard Government to facilitate adoption of this simple (non-blended) identity. No other route to harmonious multicultural relations was considered to be as effective. For example, there was minimal if any emphasis upon unity in diversity and little suggestion that the celebration of blended identity could assist relations in some, even if not all, possible social contexts.

\section{Identity threat}

The Howard Government's one-citizenship-satisfies-all approach to unity in diversity may result in threats to some of the identities comprising a blended identity. Much social-psychological research confirms that one reaction to identity threat is increased rather than decreased identification with the threatened identity, especially for those who strongly identify with the threatened identity. ${ }^{52}$ For those who highly identify with a threatened identity, and who wish to continue to selfdefine in those terms, rejection of a single Australian identity that threatens other components of their blended identity seems likely. This prediction, supported by results of designed laboratory research, has also been demonstrated in recent field studies. For example, in response to assimilationist citizenship policies in the Netherlands, Islamic groups whose religious identity was threatened strongly identified with that identity in response to public condemnation of continuing identification as a Dutch Muslim. ${ }^{53}$ Such results would be at odds with the Howard Government's claim that using (simple) notions of Australian citizenship and identity was the single most unifying force in our diverse society, producing 'a strong sense of who we are' 54

\section{Attachment to Australia}

Attachment to Australia was important for the Howard Government in 2007, stating that: 
Becoming an Australian is much more than a ceremony. It is an opportunity to fully embrace the Australian way of life, to broaden education options and employment opportunities, to vote and to have a voice in the country's future...People taking up Australian citizenship are welcomed into one of the safest, most tolerant and peaceful societies in the world. ${ }^{55}$

Davis, in his review of social-psychological theories of national attachment and his empirical study of Basque attachment in Spain, suggests that measuring subjective attachment to nation is much more complex than measuring values endorsement. Davis's review suggests that values-based attachment is important, though it can be of less importance than measures of emotional ties to nation or of institutional responsibilities. ${ }^{56}$ Even Davis's analysis of Basque attachment revealed two distinct perspectives: 'guardian nationalism' and 'apolitical ethnicity'. Only the former of those attachment styles was defined centrally around values such as language maintenance, self-determination and armed separatism. Davis also emphasised that careful empirical work was required to understand subjective attachment to nation for those self-defining in terms of blended identities; rejecting the utility of understanding attachment to nation in terms of commonly asserted and universal dimensions of attachment. ${ }^{57}$ Arab Australian Waheed Aly suggests that the Howard Government's policy of compulsory language testing and knowledge testing was mooted for political reasons and cannot provide an effective way to increase the attachment to Australia or the participation in civic life:
The tests would ask pointless questions about Don Bradman ${ }^{58}$ and Phar Lap, ${ }^{59}$ not because this assisted migrants with integration in any practical way, but because it was intended to send a symbolic message to a specific constituency in the electorate. A sector that seeks reassurance that the only migrants who will make it through are the good ones. ${ }^{60}$

Aly believes that the testing regime could emphasise a 'suffocating...p parochial cultural paradigm' ${ }^{61}$ neither giving practical help to migrants living in Australia nor improving social relations and attachment to Australia.

\section{Honourable citizenship}

Ghassan Hage fears that Australians with blended national identities in diverse societies such as Australia, who even have achieved their clear entitlements to citizenship rights, can still feel 'demeaned as a human being' 62 when accessing rights offered to them. Hage argues that most Arab migrants to Australia are 'reasonably likely to end up accessing Australian citizenship and/or the rights that come with it or with residency status' ${ }^{63}$ Therefore, he argues, the real social problems (social exclusion or isolation, inequality and discrimination) revolve around the ways in which you must access these rights and how you feel when doing so.

Hage stresses that citizenship is primarily about a (psychological) sense of belonging and about 'holding your head high' as, say, an Arab Australian. Being able to do so is, in Hage's terms, to be able to enjoy honourable citizenship. Such a form of citizenship in practice is determined by whether the legal conceptions of 
citizenship or, 'rule over the self', 64 deliver a sense of dignity, autonomy and honour. He claims that this goes beyond the common situation in diverse multicultural societies where refugees or migrants are offered a chance to belong to Australian society because they cannot or no longer wish to live in and identify with their country of origin. According to Hage, then, honourable citizenship for dual nationals means that the mode of accessing rights and the official displays of inclusion and recognition should emphasise and celebrate the continued moral worth of all elements of a blended self-identity.

Hage argues that explicit and transparent efforts be made to consider the impact on blended identities when the Australian Government makes foreign policy or other official decisions. This, in effect, would involve considering how actions taken in the Australian interest may affect those with salient blended identities. ${ }^{65}$ Honourable citizenship also means that the history and origin of, for example, an Arab identity is honoured by being given clear support as a legitimate identity with past, present and future moral worth. Making simpler calls for integration or assimilation via citizenship and identification as (only) an Australian, who speaks good English, has good civics knowledge and who endorses Australian values, may sometimes be at odds with the notion of honourable citizenship. $^{66}$

Hage concludes by encouraging Arab Australians to treat Australia as a home and to participate in Australian society despite their real fears of being discriminated against and of not being able to live their blended identities in ways they would hope. ${ }^{67}$ In saying so, he hopes Arab Australians will be encouraged not to forget their other homes. He also notes that the movement of people to Australia is dynamic, continuing and less final than it may have once been, with many migrant families now going back and forth rather than making one-movement migrations to Australia. ${ }^{68}$ In contemplating the future of the citizenship test, the Rudd Government should recognise that many Australians juggle two or more national identities. For blended identification to be matched by sensitive laws on dual or multiple citizenship, 'petty fears of double allegiance $^{\prime 69}$ must give way in law and practice to a diverse society in which blended identification can truly flourish for the benefit of all.

\section{CONCLUSION}

If one goal of Australian citizenship law is to legally recognise the reality of blended identities, governments need to create citizenship law that allows for self-definition via crossed categorisations. Outward displays of attachment to and enjoyment of all aspects of a blended identity should not engender undue moral panic. Instead, citizenship should be considered to operate richly and dynamically in ways similar to other examples of crossed categorisations unless evidence exists of unique psychological process and universally negative social psychological consequences for citizenships lived as crossed categorisations.

This article has explained that some concerns about blended identifiers - that they will be more biased or are less attached to Australia - are not sustained by research evidence. These concerns are longstanding assumptions that have been under-researched, even by identity psy- 
chologists. $^{70}$ The way in which citizenship law and policy creates tension between elements of blended identities is important:

These identities do not have to
contradict each other or get in
each other's way because they are
of different kinds: they are differ-
ently defined or situated on differ-
ent levels of abstraction. One can
be a member of an ethnic group as
well as a superordinate national
category. There is little problem
as long as these identities are not
defined on the same level of ab-
straction and in contrasting or
competing terms. Depending on
the situation the one or the other
is relevant and becomes salient.
However, different identities do
sometimes get in each other's
way.

Blended identity salience is a dynamic and context-dependent process, and is not a fanciful, postmodern, theoretical concept. It is the lived reality for many citizens. The celebration of blended identity rather than the ascription of an ill-fitting singular Australian identity may be a better way to encourage psychological attachment to the many ways in which Australian citizenship can be enjoyed.

\section{POSTSCRIPT}

The Rudd Government released the report of the Australian Citizenship Test Review Committee, Moving Forward...Improving Pathways to Citizenship, and the government response to that report after this article was written (see <http://www.citizenshiptestreview.gov.au/index.htm>).
Kim Rubenstein was a member of the committee. When the government releases the new citizenship test and the pathways to taking the test as a result of its response to the report, we will then be able to consider how well the changes deal with the issues raised in this paper.

\section{ENDNOTES}

1 See reforms as discussed below. Note also that on 24 January 2007, the Department of Immigration and Multicultural Affairs was renamed the Department of Immigration and Citizenship.

2 The Minister for Immigration and Citizenship established an independent committee to review the Citizenship Test in April 2008 (see < http://www.citizenshiptestreview.gov.au/ >).

3 Dauvergne, C. 2005, Humanitarianism, Identity and Nation: Migration laws in Canada and Australia, UBC Press, Vancouver, pp. 166-221; Mamdani, M. 2001, When Victims Become Killers: Colonialism, nativism, and the genocide in Rwanda, Princeton University Press, Princeton, NJ, p. 22; Purvis, T. and Hunt, A. 1999, 'Identity versus citizenship: transformations in the discourse and practice', Social and Legal Studies, vol. 8, no. 4, pp. 457-82; Reicher, S. 1986, 'Contact, action and radicalisation: some British evidence', in M. Hewstone and R. Brown (eds), Contact and Conflict in Intergroup Encounters, Basil Blackwell, Oxford, pp. 152-68; Ramos, E. Rivera 2001, The Legal Construction of Identity: The judicial and social legacy of American colonialism in Puerto Rico, American Psychological Association, Washington, DC.

4 Abu-Saad, I. 2006, 'State-controlled education and identity formation among the Palestinian Arab minority in Israel', American Behavioral Scientist, vol. 49, no. 8, pp. 1085-100.

5 Oakes, P. J. 1987, 'The salience of social categories', in J. C. Turner, M. A. Hogg, P. J. Oakes, S. Reicher and M. Wetherell (eds), Rediscovering the Social Group, Blackwell, Oxford; Oakes, P. J., Turner, J. C. and Haslam, S. A. 1991, 'Perceiving people as group members: the role of fit in the salience of social categorizations', British Journal of Social Psychology, vol. 30, no. 2, pp. 125-44.

${ }^{6}$ Where a broad range of personal aspects, including affiliations with groups, may help define a collective or blended identity: Simon, B. and Hastedt, C. 1999, 'Self-aspects as social categories: the role of personal importance and valence', European Journal of Social Psychology, vol. 29, no. 4, pp. 479-87. See also Simon, 


\section{Citizenship and identity in diverse societies}

B. 1997, 'Self and group in modern society: ten theses on the individual self and the collective self', in R. Spears, P. J. Oakes, N. Ellemers and S. A. Haslam (eds), The Social Psychology of Stereotyping and Group Life, Blackwell, Oxford, pp. 318-35.

7 Cashmore, E. 2003, 'The impure strikes back', British Journal of Sociology, vol. 54, no. 3, pp. 407-14, 411, citing Kumar, K. 2003, The Making of English National Identity, Cambridge University Press, Cambridge, p. 258.

8 Ibid., p. 411, citing Anthias, F. 2001, 'New blendedities, old concepts: the limits of "culture", Ethnic and Racial Studies, vol. 24, no. 4, pp. 619-41, 637.

9 Korac, M. 1996, 'Understanding ethnic-national identity and its meaning: questions from women's experience', Women's Studies International Forum, vol. 19, no. 1-2, pp. 133-43; Verkuyten, M. 2005, The Social Psychology of Ethnic Identity, Psychology Press, London.

10 Duany, J. 2003, 'Nation, migration, identity: the case of Puerto Ricans', Latino Studies, vol. 1, no. 3, pp. 424-44; Glazer, N. 2004, 'Assimilation today: is one identity enough?', in T. Jacoby (ed.), Reinventing the Melting Pot: The new immigrants and what it means to be American, Basic Books, New York, pp. 61-73; Mahtani, M. 2002, 'Interrogating the hyphennation: Canadian multicultural policy and "mixedrace" identities', Social Identities, vol. 8, no. 1, pp. 67-90.

11 Mullen, M., Migdal, M. J. and Hewstone, M. 2001, 'Crossed categorization versus simple categorization and intergroup evaluations: a meta-analysis', European Journal of Social Psychology, vol. 31, no. 6, pp. 721-36.

12 For an early example of experimental research with crossed categorisations, see Brown, R. J. and Turner, J. C. 1979, 'The criss-cross categorization effect in intergroup discrimination', British Journal of Social \& Clinical Psychology, vol. 18, no. 4, pp. 371-83.

13 Verkuyten, M. 2007, 'Religious group identification and inter-religious relations: a study among Turkish-Dutch Muslims', Group Processes and Intergroup Relations, vol. 10, no. 3, pp. 341-57.

14 Ibid.

15 Ibid., p. 343: supporting observations from H. C. Triandis (1992, 'Comments on Hinkle, Brown and Ely', Revisita de Psicologia Social, vol. 3, pp. 113-23) that for some identifications in some cultures, one is clearly a (strongly identified) member of a group or one is not. This could mean that group identification is a binary choice rather than a form of belonging that can be measured on a continuum in terms of low and high identification. Being a low identifier with these identities is not an option.
16 Ibid., p. 347.

17 Ibid., p. 351.

18 Hornsey, M. and Hogg, M. 2000, 'Subgroup relations: a comparison of mutual intergroup differentiation and common ingroup identity models of prejudice reduction', Personality and Social Psychology Bulletin, vol. 26, pp. 242-56.

19 Crisp, R. J., Walsh, J. and Hewstone, M. 2006, 'Crossed categorization in common ingroup identity contexts', Personality and Social Psychology Bulletin, vol. 32, no. 9, pp. 1204-18.

20 Purvis and Hunt, 'Identity versus citizenship', p. 458.

21 Hopkins, N., Reicher, S. and Kahani-Hopkins, V. 2003, 'Citizenship, participation and identity constructions: political mobilization amongst British Muslims', Psychologica Belgica, vol. 43, no. 1-2, pp. 33-54, 34.

22 Turner et al., Rediscovering the Social Group.

23 Hopkins et al., 'Citizenship, participation and identity constructions', pp. 42, 39.

24 Ibid., p. 42.

25 Ibid., p. 34.

26 Zevallos, Z. 2003, “That's my Australian side". The ethnicity, gender and sexuality of young Australian women of South and Central American origin', Journal of Sociology, vol. 39, no. 1, pp. 81-98.

27 Ibid., pp. 88-9.

28 Ibid., p. 85 .

29 For a more detailed examination of dual citizenship in Australia, see Rubenstein, K. 2002, Australian Citizenship Law in Context, Law Book Company, Sydney.

30 See Parliament of the Commonwealth of Australia (1994, Australians All: Enhancing Australian citizenship, Joint Standing Committee on Migration, ch. 6), where it is stated that the issue of dual citizenship attracted most attention throughout the inquiry.

31 Parliament of Australia 1997, Aspects of Section 44 of the Australian Constitution, Standing Committee on Legal and Constitutional Affairs, July 1997.

32 Introduced by Act No. 11 of 1966, s. 11 (commenced 6 May 1966) and repealed by Act No. 70 of 1986, s. 11 (commenced 28 August 1986).

33 Judgment of 6 April 1955: ICJ Reports 1955, p. 4.

34 (No. 2) (1992) 176 CLR 77.

35 Australian Citizenship Council 2000, Australian Citizenship for a New Century, p. 65, < http://www.citizenship.gov.au/law-and-policy/legislation/report.htm> 
36 The Readers' Guide is available at < http://www.citizenship.gov.au>

37 Ibid., pp. 78-81.

$38 \quad$ See <http://www.pm.gov.au/media/release/2005/media_Release 1551.cfm $>$. In particular, they include extending the waiting period for obtaining citizenship, security checking of citizenship applications, so that citizenship applications can be refused on security grounds, and strengthening the deprivation of citizenship provisions relating to serious criminal offences to include offences committed in the period between approval of an application and acquisition of citizenship.

39 It was introduced into the House of Representatives on 30 May 2007 (see <http://parlinfoweb.aph.gov.au/piweb/Repository/Legis/Billsdgs/YREN60.pdf $>$, viewed 24 February 2008), and the act that it was seeking to amend came into force on 1 July 2007.

40 Australian Government 2006, Australian Citizenship: Much more than a ceremony, September 2006, pp. 8-9.

41 As a result of amendments reflected in the Australian Citizenship Act 2007 (Cth), ss 21(2)(d)-(f), 21(2A), 23A, 46(1A) and 53(2).

42 Rimmer, S. Harris 2007, 'Australian Citizenship Amendment (Citizenship Testing) Bill 2007', Bills Digest, Parliamentary Library of Australia, no. 188, 19 June 2007, viewed 24 February 2008, <http://parlinfoweb.aph.gov.au/piweb/Repository/Legis/Billsdgs/YREN60.pdf>

43 See information about the test and a link to the booklet at <http://www.citizenship.gov.au/test/resource-booklet/citz-booklet-full-ver.pdf $>$ (viewed 24 February 2008).

44 See <http://www.citizenship.gov.au/resources/facts-and-stats/citz-stats.htm $>$ (viewed 24 February 2004).

45 See <http://www.citizenship.gov.au/resources/facts-and-stats/citz-stats.htm $>$ (viewed 22 September 2004) and the latest report available at <http://www.citizenship.gov.au/_pdf/citztestsnapshot-report-2008-june.pdf $>$ (viewed 22 September 2008).

46 Hage, G. 2002, 'Citizenship and honourability: belonging to Australia today', in G. Hage (ed.), Arab Australians Today: Citizenship and belonging, Melbourne University Press, Melbourne, p. 3.

47 Australian Government, Australian Citizenship, p. 8.

48 The words 'under God' are optional.

49 Australian Citizenship Act 2007 (Cth), Schedule
50 Zevallos, “"That's my Australian side"”, p. 86.

51 Australian Government, Australian Citizenship.

52 Spears, R., Doosje, B. and Ellemers, N. 1997, 'Selfstereotyping in the face of threats to group status and distinctiveness: the role of group identification', Personality and Social Psychology Bulletin, vol. 23, pp. 538-53; Branscombe, N. R., Ellemers, N., Spears, R. and Doosje, B. 1999, 'The context and content of social identity threat', in N. Ellemers, R. Spears and B. Doosje (eds), Social Identity: Context, commitment, content, Blackwell Science, Oxford, England, pp. 35-58.

53 Verkuyten, M. and Zaremba, K. 2005, 'Inter-ethnic relations in a changing political context', Social Psychology Quarterly, vol. 68, pp. 375-86.

54 Australian Government, Australian Citizenship.

55 Ibid., p. 11.

56 Davis, T. C. 1999, 'Revisiting group attachment: ethnic and national identity', Political Psychology, vol. 20, no. 1, pp. 25-47.

57 Ibid., pp. 32-3.

58 An Australian cricketer.

59 An Australian racehorse and winner of the Melbourne Cup.

60 Aly, W., 'End of the culture wars', viewed 14 January 2008, <http://www.australiansall.com.au/the-end-of-the-culture-wars/>

61 Ibid.

62 Ibid.

63 Hage, 'Citizenship and honourability', p. 2.

64 Ibid., p. 3.

65 Ibid., p. 10.

66 Ibid., p. 11.

67 Ibid., pp. 14-15.

68 Ibid., p. 12.

69 Ibid., p. 13

70 Verkuyten, 'Religious group identification and inter-religious relations', p. 344.

71 Ibid. 


\title{
POPULATION POLITICS IN THE FASCIST ERA
}

\author{
Austria's 1935 population index
}

JULIE THORPE

Laws regulating immigration and citizenship in interwar Austria were part of a European trend of population politics in fascist and authoritarian states in the 1930s. A new proposal in 1935 for a population index, including identity cards for every person residing in Austria, was modelled on Italian legislation and signalled a shift towards totalitarian models of population management. While Austria's population index system was never implemented before Austria's annexation to Nazi Germany in 1938, it corresponded nonetheless to a broader pattern of fascist and authoritarian population policy across Europe in the interwar era. Official and public debates about the proposed population index reveal the dual aims of Austrian policy and opinion makers: first, to facilitate greater surveillance of citizens and non-citizens; and second, to reduce the number of Jews in Austria either through restricting immigration or by precluding Jews already residing in Austria from being naturalised. This connection between racism, migration and citizenship in the Austrian case illustrates the convergence of different strands of population politics as fascist and authoritarian states attempt to forge new citizens. Moreover, the interwar Austrian case highlights the interplay between exclusionary practices of nationalism and citizenship and successive waves of mass migration during the twentieth century. ${ }^{1}$ My article places the Austrian case within these broader processes of citizenship and state building in early twentieth-century Europe, but parallels could also be drawn with other post-imperial or post-colonial states.

\section{FASCISM AND POPULATION POLICY}

Despite dozens of specialised and comparative studies and definitions of fascism, scholars have yet to reach a consensus about what fascism is, and where it took root and came to power in the years between 1918 and 1945 in Europe. ${ }^{2}$ If scholarship on the interwar European regimes and movements still does not have a clear and comprehensive definition of fascism, it has made virtually no headway into the murky hues of 'authoritarianism', a category scholars use loosely to characterise a broad range of states that appear to have some similarities with the accepted fascist states - Italy and Germany-but lack the mass movement, charismatic leader and popular consent that characterise the regimes in Italy and Germany. The 
Austrian dictatorship under Engelbert Dollfuss and Kurt von Schuschnigg (the latter took office as Chancellor after Dollfuss' assassination by Austrian Nazis in July 1934) typically falls into this latter category of authoritarian states that also exhibit elements of fascism. Lasting approximately five years from the dissolution of parliamentary democracy in March 1933 to annexation to Nazi Germany in March 1938, the regime constitutionally known as the Ständestaat, or corporate state, had a paramilitary force (the Heimwehr or home guard), state youth groups, welfare programs promoting motherhood as a patriotic duty and a one-party organisation, the Fatherland Front, of which membership was compulsory for teachers and public servants. Historians of the Dollfuss-Schuschnigg state, seven decades after it ceased to exist, have been reluctant to move beyond the outdated and clumsy opposition of 'fascist' versus 'authoritari$\mathrm{an}^{\prime}$ in their characterisations of the State-an approach pioneered by Hugh Seton-Watson and John Rath, notably, and modified only slightly by others such as Francis Carsten and Gerhard Botz. ${ }^{3}$

More recent attempts to see fascism as a trajectory of radicalising right-wing tendencies, rather than as a fixed category or 'type', have been more successful in shifting the debate away from a fascistauthoritarian dichotomy towards a more fluid definition emphasising processes over outcomes. ${ }^{4}$ Scholars who follow a process-oriented approach to the Austrian state, for example, argue that the regime represents a fascistising trajectory cut short by the country's annexation to Nazi Germany in 1938, though this is still the minority view. ${ }^{5}$ Such a conceptual and historiographical shift in studies of fascist and authoritarian regimes in Europe also allows us to look more closely at the radicalisation of certain political, social and economic policies that seek total control of society. Historians have questioned the extent to which such policies did in fact result in conformism by the population, especially when we consider the sphere of everyday life within the constraints of official ideology: the experiences of women in particular teach us much about the limits of popular consensus as dictatorships attempted to rule over even the most private of citizens' choices, such as whether to procreate for the State. ${ }^{6}$ But questions remain unanswered in some respects: how did fascist and authoritarian states seek to exert control over their citizens; and how did this function to produce particular kinds of citizens or a particular notion of citizenship? This article shows the validity of the process-oriented approach to fascism for studies of population politics in the interwar period and in the Austro-fascist state. It does this, moreover, by demonstrating how fascist states sought to define the relationship between citizens and the State by evergreater controls over citizens' mobility and choice of residence, and by ever-closer surveillance of citizens' recorded lives from cradle to grave. In this way, the relationship between fascism and citizenship can be seen as symbiotic processes of categorising, counting and excluding individuals in order to build and legitimise states.

Many studies of population politics under fascist and authoritarian regimes have explored the eugenics and pro-natalist policies of the regimes, ${ }^{7}$ but so far another area of population management - migration and citizenship - has received little 
attention. This oversight is surprising since arguably this aspect of population control reinforces the regimes' eugenics and pro-natalist programs. Carl Ipsen has argued that fascist population politics in Italy were characterised by a range of measures spanning nuptiality, fertility, mortality, emigration and internal migration: the Italian Fascist Deputy, Gaetano Zingali, explicitly referred to 'this famous demographic quintet' in a 1929 speech to Parliament. ${ }^{8}$ By exploring these multiple fronts of Mussolini's 'demographic battle', Ipsen extends the debate beyond Mussolini's 'battle for births' to include a spectrum of policies that the regime itself saw as part of a larger battle to create 'a new Fascist society'. 9

Ipsen's analysis of fascist population policy in Italy merits further exploration here because of his emphasis on policies of migration and colonisation. Moreover, Italy makes for a particularly relevant comparative case study with the Austrian case because of a number of 'relational' elements between the two cases, as we will see below. ${ }^{10}$ Finally, although fascist population policy in Italy, unlike in Austria, did not seek to control immigration into the country, but rather to restrict emigration from Italy and regulate internal migration, the Italian case nevertheless highlights the interacting processes of citizenship practices, migration and other radicalised notions of population management under fascist governments.

\section{EARLY POPULATION POLICY IN FASCIST ITALY (I922-29)}

In the years of consolidating fascist rule in Italy between 1925 and 1929, the regime initiated a number of measures of popula- tion control that broke decisively with the liberal era, which had witnessed soaring emigration abroad in order to ease the economic burden of the overpopulated and impoverished regions in southern Italy. ${ }^{11}$ Whereas the first few years of fascism saw the regime continue to champion liberal policies on emigration, after 1925, Italian migration policy shifted focus from external to internal migration. In November 1926, a Public Security Law made all passports held by Italians in Italy invalid. Less than a year later, strict eligibility criteria for new passports were introduced-for example, only individuals with a work contract with an employer who was not a direct relative of the employee could be issued with a new passport. In 1930, fines and penalties were introduced for assisting or engaging in clandestine emigration. Repatriation taxes were removed to encourage return migration of Italians working abroad and terminology was changed to reflect the regime's new priority of bringing Italian workers home. The formerly named General Emigration Commission (CGE), the government department responsible for Italian emigration, was renamed in 1927 the General Directorship of Italians Abroad (DGIE) after Mussolini declared the word 'emigrant' defunct. ${ }^{12}$ Carlo Levi describes the return émigrés as 'Americans' in his memoir of his political exile in the south under fascism, Christ Stopped at Eboli, written in the last years of Mussolini's rule. His use of the word was probably not a politically inspired choice, though it does evoke a local experience of politics in the south, ranging from the comic - the images of Roosevelt in place of Mussolini on their walls - to the tragic fate of those whose visit home to see relatives became 
their own exile after losing their American riches in the Great Depression and being forced to stay and marry in the village they had tried to leave. ${ }^{13}$ The fascist regime also sought to discourage migration to cities by providing housing and transport for rural workers to work on state projects and subsidising charities that assisted state programs of internal migration. ${ }^{14}$ While these new policies were partially a reaction to international restrictions on migration, they cannot be seen solely in terms of a pragmatic response to external pressures since the United States - the country with the highest intake of Italian emigrants - introduced its immigration quotas in 1921 and again in 1924, some years before the laws on passports and internal migration were enacted in Italy. Rather, as Ipsen states, placed in the broader context of Italy's 'demographic quintet', Italian migration policy 'came on the heels of-and as an integral part of - the general move towards totalitarian social control initiated in January 1925' ${ }^{\prime}$

Similarly, we can see the regime's efforts to centralise demographic statistics as part of a larger trend in European fascist and authoritarian regimes. State institutions for analysis of demographic statistics were established in Hungary and Poland in the 1930s, a few years after Italy founded its Central Statistics Institute of the Kingdom of Italy (ISTAT) in 1926. ${ }^{16}$ At the ceremonial inauguration of the new institute, Mussolini announced that in the fascist state, statistics would no longer be the sterile pursuit of numbers far from government corridors. Rather, 'the suggestive eloquence of figures' demanded their central place not just in the government but in universities as statistics entered the mainstream disciplines of law and political science to train the next generation of statisticians. ${ }^{17}$ Figures could stir patriotic emotion in their viewer, just as speeches or songs could in their hearer, but while songs and speeches were aimed at an uneducated mass of devoted followers of $I l$ Duce, statistics would capture the hearts and minds of university students and senior civil servants. The Fascist Deputy, Zingali, adept at turning fascist policy into an eloquent phrase, declared in his 1929 speech that in fascist Italy 'not only men, but also statistical data, have become dynamic, almost as if following with the same insistent rhythm the course of these glorious times'. ${ }^{18}$ As professor of statistics and economics at Catania, appointed deputy in Mussolini's government, Zingali himself embodied the rhythmic synthesis of numbers and oratory.

While statisticians were being elevated to new positions in government and academia, ISTAT gained control over all demographic statistics except for migration, which were collated and published by the various government agencies for emigration and colonisation: the CGE/DGIE for emigration, the Commission for Migration and Colonisation (CMC) and Permanent Committee for Internal Migration (CPMI) for migration within Italy. ${ }^{19}$ The municipal population registers, which had collated and stored data on internal migration since 1862, formed a third body for demographic statistics. Whenever a person arrived in a new municipality, or commune, he or she would be registered and when they left the commune this record was cancelled. In addition to arrivals and cancellations, the population registers also recorded births, deaths and marriages. Legislation introduced in Italy in 1929 centralised the population registers by 
giving authority to ISTAT to collect and store data on the population. Under the new legislation, ISTAT could instruct municipal authorities on record keeping and in turn municipalities were required to hand over their annual population registers to ISTAT. Omitting to report a birth or change of residence was a punishable offence, for example. And since most records of births, deaths and marriages were held in local parishes, the 1929 law effectively made parish activities subject to state surveillance and control, which strictly speaking was a violation of the Lateran Accords regulating church-state relations. 20

The centralising powers of ISTAT were constrained, however, by the fact that responsibility for data collection and collation lay ultimately at the municipal level with the mayor. Nor did ISTAT have access to full data on clandestine urban migration, which Mussolini sought initially to discourage through the colonisation projects and eventually banned in 1939. 21 This limitation was a bone of contention for Italy's leading demographer in the fascist period, Corrado Gini, president of ISTAT from 1926 to 1932. Gini wanted to give more power to his organisation by employing state-trained statisticians, rather than local authorities, to collect data for the 1931 census. ${ }^{22}$ Although his proposal was rejected by the Interior Ministry, it showed that state functionaries planned to extend the powers of the State even further. The fact that Gini's proposal stalled does not imply its lack of reception among fascist policy makers, but rather, could simply indicate a lack of financial and human resources during these early years of consolidating power.
The above discussion sets up a broader context within which to evaluate Austria's population policies in the 1930s. I have already noted that the regimes in Poland and Hungary centralised their demographic systems in the 1930s. These developments outside Italy were entangled with the political changes inside Italy, not only at the level of government but, as we have seen, in the areas of higher education and scientific pursuits. Demographers outside Italy would certainly have been aware of Gini's cyclical theory of population growth, which had already reached an international audience years before the fascist regime came to power, and Gini's influence on Italian policymakers in turn influenced Austrian policymakers, as we will see. ${ }^{23}$ Aside from demographic statistics, Italy's influence on the Austro-fascist state was evident in a number of other ways, directly and indirectly: in the merging of press and propaganda bureaus into a single ministry, for example, as well through Italy's supply of finances and weaponry to the Heimwehr. ${ }^{24}$ Mussolini was also a close friend of the Dollfuss family: the Austrian Chancellor's wife and children were houseguests of Il Duce when Dollfuss was gunned down in the Hofburg Palace in July 1934. Therefore, despite fascism's inability to achieve the kind of expansion of state powers that functionaries such as Gini wished for, Italy was still a model example of population management in the interwar years.

\section{AUSTRIA'S POPULATION INDEX}

Italy's influence on Austrian policymakers is demonstrated by the legislation for a population index drafted between 1935 
and 1938 by Austria's Federal Council of Culture (Bundeskulturrat). This legislation was modelled directly on the 1929 laws enacted in Italy. As in the case of Gini's proposal to the Interior Ministry in 1931, the legislation in Austria was eventually rejected because of a lack of finances, but it illustrated, nonetheless, the State's plan to achieve greater control over the population. The Austrian case also highlights the regime's intent to curb 'undesirable' immigration and residency in Austria, specifically of Jews. In the legislative and public discourses about the proposed legislation, therefore, we can trace Austria's 'demographic battle' on several fronts: citizenship, immigration and anti-Semitism.

The first ministerial discussions about the proposal for a population index in Austria took place in June 1935. In its earliest form, the scheme consisted of a system of compulsory registration for every adult resident in Austria whether citizen, foreigner or stateless. The registration of the entire population was intended to lay the groundwork for further administrative reforms and also for a new military service law. ${ }^{25}$ The Federal Council for Culture, one of four government legislative councils created under the May 1934 constitution that formally marked the end of parliamentary democracy in Austria and the period of Austro-fascist rule, ${ }^{26}$ then met to discuss the proposal in September 1935. The Speaker, Dr Lenz, stated at the outset of his address to council that the population index was to be the first of several measures aimed at reforming Austria's entire legal and administrative system of residency, immigration and welfare. He also placed the proposal for a population index in the broader European con- text by claiming that industrial change and the economic crisis had transformed Europe from a 'culture of settling' to a 'culture of migrating'. Austria was 'perhaps the state of least resistance against socially undesirable elements' and for this reason it had been necessary to include foreigners as well as Austrian citizens in the population index. Just who these 'socially undesirable elements' were was plain from his claim that the increased numbers of stateless people had become an 'international affliction' on the Austrian state due to the reluctance or unwillingness of Austria's neighbours to take in former Austrian citizens who were now stateless. $^{27}$

The reference to stateless people in Austria was a reference to those former citizens of the Austro-Hungarian Empire who had been ineligible for citizenship in the new Austrian state under laws designed to exclude those who had resided in territories outside the borders of the new state before 1914. The new legislation on citizenship was promulgated on 5 December 1918, less than a month after the declaration of the Republic of 'GermanAustria' on 12 November 1918. ${ }^{28}$ The law restricted citizenship to those whose legal residence (Heimatrecht) had been in the territory of the republic before August 1914. This meant that refugees from the empire's borderlands who after 1918 found themselves on the territory of GermanAustria were excluded from citizenship in Austria. The 1918 law directly affected the 70000 Jewish refugees from Galicia who had remained in Vienna after the war but could not claim their place of domicile in the new Austrian state. A legal loophole for these refugees was introduced a year later under Article 80 of the Treaty of 
Saint-Germain at the end of 1919. Under the terms of Article 80, citizens of the former Austro-Hungarian Empire could opt for citizenship in any successor state in which they identified 'according to race and language' with the majority of the state's population. Article 80 was adopted into Austrian legal practice in August 1920 with the proviso that proof of one's identification with the German language by way of graduation certificates from German primary, secondary or tertiary schools had to be shown in citizenship claims. This was an exercise in vain for many Jewish refugees who had no such proof available and for whom retrieval of the necessary documents was next to impossible and, even if they had been able to prove their German language credentials, anti-Semitic bureaucrats in the interior ministry and federal administrative court could still reject applications for citizenship on the grounds of race instead of language, given the ambiguity of the wording of Article 80. 29 Nonetheless, despite the legal obstacles to acquiring citizenship, the number of naturalisations including those of Jews did not decline significantly until after 1933 when a moratorium was placed on all naturalisations in Austria. Approximately 120000 individuals were naturalised between 1919 and 1936, and a further 20000 were naturalised under the terms of Article 80. ${ }^{30}$ Thus, the move to freeze citizenship claims in 1933 came after a series of measures that defined citizenship in Austria according to language and ethnicity as well as territory. After 1933, citizenship was defined not only in ethnic and territorial terms, but in civic terms of ideological loyalty to the State. Loyalty to the State could be demonstrated through continuous residency and work in one place, which excluded foreign workers and refugees from becoming Austrian citizens.

In his comments on the draft legislation, Lenz referred directly to Italy's 1929 law, on which the Austrian population index was modelled, and he recommended in line with the 1929 law that state inspectors be appointed to oversee the registration process and the various registry offices. And, like the Italian Interior Ministry, the Austrian legislators stopped short of Gini's recommendation that the State itself appoint professionals to carry out the registrations at the municipal level. The parallels with Italy can also be seen from the Austrian proposal to include in addition to the population index a compulsory identification card (Erkennungskarte) to be issued to every person over the age of eighteen, modelled on the Italian Carta d'identità. The Austrian card was to function as a domestic passport and would include the person's photograph, address, date of birth, nationality, occupation and any changes of occupation. As in Italy, the purpose of the identity cards was to help individuals better identify with the State by reminding them of their social obligations to the State: work and loyalty to one's country of birth. ${ }^{31}$

However, there is one important difference between the Italian and the Austrian models that highlights the racial 'front' in Austria's demographic battle, one not witnessed in Italy until after the Axis pact between Mussolini and Hitler in 1935 and Italy's invasion of Ethiopia in 1936. Unlike in Italy, where individuals and families were registered separately, the Austrian population index was to include details about an individual's family on the same index sheet. As Lenz pointed out in the 
legislative discussions in the Federal Council for Culture, the inclusion of an individual's family details was deliberately designed to require Austrian citizens to declare any business and family links outside of Austria. ${ }^{32}$ As we will see below in the press discussions of the proposed law, the concern that some Austrians were supporting family members who were not Austrian citizens was directed primarily at Jews who had arrived in Vienna as wartime refugees and had been unable to prove their German linguistic and cultural credentials in the new Austrian state after the war. Even if the government did not articulate this concern directly, the implication in official statements was that certain foreigners in Austria were 'undesirable'. For example, the Interior Minister, Emil Fey, said in an address to the Federal Council of Ministers, which appeared in the press the next day, that the longstanding practice in Austria, as in Italy, that individuals had to register in the municipality where they had their legal residence, had led to many discrepancies between municipal records and also had allowed the 'non-Austrians' to stay out of the authorities' clutches. ${ }^{33}$ In 1932, the Interior Ministry had deemed Nazis and communists 'undesirable': the Czechoslovakianborn German communist Egon Erwin Kisch had been denied entry to Austria on the grounds that his proposed lecture on Russia and China contained 'communist propaganda' that would undermine public order. ${ }^{34}$ And in 1933, after the ban on the Nazi Party stripped Austrian Nazis who had left the country of their citizenship, statements about unwanted foreigners may have been taken to mean Nazi terrorists on Austrian soil. But by 1935, with the new Chancellor Schuschnigg broaching a more conciliatory position towards Hitler and the underground Austrian Nazis, the proposed requirement that individuals declare their non-Austrian relatives to the authorities seemed to target a different group of foreigners: Jews fleeing persecution in Germany.

Moreover, the category included not only 'tramps', one council member observed, but also performers and artists who stayed in a particular place for only two months, a comment that drew the mirth of other council members. Apparently what struck the council as funny were the many prominent Jewish theatre directors, actors and other performers who had come to Austria from Germany since 1933, often staying only for the annual summer season of the Salzburg Festival before emigrating to America, and who were the butt of many anti-Semitic jibes during the festival. The festival season had just finished, but now a more sinister joke was to be played on them as the council moved to stamp 'ST' - abbreviated from 'stichtag' or expiration date- on their identification cards. ${ }^{35}$

One week after the Federal Council for Culture passed the proposed legislation for a population index and identification cards, the Minister of the Interior, Emil Fey, addressed the State Council on the proposed bill. His address was reprinted the next day in the Neue Freie Presse. Fey echoed the earlier claims by Lenz that the population index was to be the first of many new measures intended to overhaul the administration of the interior ministry, which Fey claimed had allowed 'undesired foreigners' and stateless individuals to enter and reside in Austria. The necessity of clamping down on unwanted immigration was also the reason why every resid- 
ent of Austria-citizen and non-citizen - was to be included in the proposed index system. He singled out the police registration system as an immediate area in need of reform: the longstanding practice in Austria, as in Italy, was that individuals had to register in the municipality where they had their legal residence. But, according to Fey, that system had led to many discrepancies between municipal records and also had allowed the 'nonAustrians' to stay out of the authorities' clutches. Minister Fey endorsed the identification cards as a way to simplify the current system, although he acknowledged the new system would be a burden in the short term for the population who would be required to register for the new cards, and for the authorities who had to implement the new system. But in the long run, the benefit of the system would be seen in the permanent contact between the individuals and the authorities, which would cultivate a 'vibrant sense of belonging to the state' and thereby serve the larger purpose of building a new state from the bottom up. 36

The next year, true to Fey's word, the Austrian Migration Office produced the first draft of a new Alien Act to regulate the status of foreigners in Austria through a foreigner index system. The scheme built on the earlier proposal for a population index and was based on similar laws already in place in neighbouring countries, including Czechoslovakia, which had passed an Alien Act in March 1935. The legislation underwent three revisions over an 18-month period but, like the legislation for a population index, it was not implemented before Austria's annexation to Germany in March 1938. In the final stages of negotiation, in January 1938, the gov- ernment administration conceded that a system of indexing all 290000 foreigners in Austria was too costly an exercise and settled instead on a register for all those who had arrived in Austria since 1 January 1933. ${ }^{37}$ The Alien Act was significant, nonetheless, because it revealed the full extent to which Austria's politicians were ready to mobilise the State's powers to curb what they perceived was a wave of uncontrolled immigration that, if left unchecked, could potentially open the floodgates to more desperate and destitute refugees, genuine or otherwise.

\section{PUBLIC DEBATES ON POPULATION POLICY IN AUSTRIA}

By 1937, Austria's right-wing newspapers were also lending their support to a new population index and immigration law with the same anti-Semitic overtones as the council chamber discussions of the bill. It must be noted here that the Austrofascist state had banned the social democratic press and the Nazi Party organs, and had appointed commissioners over the editorships of the German-nationalist newspapers, which dominated the small provincial towns such as Linz, Graz and Salzburg. The German-nationalist newspapers in particular came under heavy scrutiny by the censor for their pro-Hitler sentiments. But on other issues, such as minority politics, or the immigration debate, these newspapers could also be counted on to support the Austro-fascist government. 38 In Graz, the Volksblatt welcomed new legislation to restrict foreigners living and working in Austria, claiming that foreign workers in Austria were taking jobs from unemployed Austri- 
ans and citing Carinthia as an example, with 11000 foreign workers and 15000 'native' Austrians out of work. ${ }^{39}$ The Styrian Tagespost also justified a more restrictive immigration policy by inferring that nearly all foreign workers in Austria were Jews. An editorial on 16 February 1937 claimed that as many foreigners had gained employment in Vienna in 1936 as Austrians had been looking for work. It alleged that foreigners exploited the Austrian economy by taking the profits outside the country, enabling the families of these foreigners to seek passage to Austria at the expense and exploitation of Austrian families. 40

In Vienna, the Wiener Neueste $\mathrm{Na}$ chrichten ran six headline stories on the 'invasion' of Jews from Eastern Europe in a two-month period alone. ${ }^{41}$ In its New Year's Eve article in 1937, the newspaper called for a border block against theJews: 'Austria needs an immigration law that takes into account the changing circumstances and protects the native population from the invasion of a locust swarm from the east.' 42 Two days later, the newspaper published a letter to the editor, affirming the editorial's view that it 'is the uncontested right of the state to ban or control immigration...Austria needs neither the labour nor the financial ownership of the Eastern European Jews'. 43 A notice in the Wiener Neuste Nachrichten for a public lecture series on 'The foreign guest in Austria' suggested that there were more than a few anti-immigration activists among the newspapers' readers and editors alike. 44

The newspapers tended to conflate the refugees during World War I and those from Germany after 1933 into one ostens- ible flood of unwanted Jewish immigration. The Tagespost claimed that

[t]hese foreigners belong almost entirely to a certain group of political emigrants, who have once already moved to Austria and above all to Vienna in order to settle there, albeit partly for different reasons then. During the war and immediate post-war years, this influx, which was by no means always wanted as later became painfully apparent, came from the East. Now it is coming from the West. ${ }^{45}$

The Wiener Neueste Nachrichten also drew parallels between the wartime and post-1933 immigration. A front-page editorial on 17 December 1937 suggested that Austria was an attractive destination for German Jewish refugees because they had relatives in Vienna who had arrived from Poland and Russia after the war. The editorial claimed that attempts by the Austrian authorities to restrict immigration would be impossible, due to the well-organised, clandestine smuggling groups who allegedly provided false identity papers for the refugees. The newspaper estimated that between 100 and 150 people arrived without passports each month and found lodging and black-market work in Austria, prompting the newspaper to sound a clarion call for tighter controls on Jewish immigration: 'Protect our borders and our country from a new flood of Eastern European Jews!' 46

Such was the vehemence of these newspapers' anti-immigration lobby that even The Times correspondent in Vienna, Douglas Reed, noted their sentiments. He reported that Austria had 'been flooded 
with immigrants from Germany and Poland, a fair proportion of whom have criminal records' and he predicted that 'a closer scrutiny is inevitable sooner or later'. He defended these sentiments as having 'nothing to do with anti-Semitism' and informed his English readers that the 'bulk of opinion in Austria sympathises with the views of these two newspapers'. 47 Reed's broad brushstrokes painted a sympathetic picture abroad that the Austrian authorities could scarcely have hoped for as vindication for their brand of population politics.

Population policies in Austria, as in Italy, were 'audacious in their aspirations but modest in their accomplishments', constrained as they were by the economic crisis in the 1930s. ${ }^{48}$ Not only in fascist regimes, but elsewhere in Europe-in France, Britain, Belgium and Holland-as well as further afield in the United States and Australia, attempts to regulate the entry and residency of foreigners were a feature of protectionist labour policies against foreign workers. ${ }^{49}$ But it was in fascist states that the legislation rapidly extended beyond economic protectionism to encompass the wider political and social spheres of citizens' everyday lives: from one's place of baptism and marriage to one's position of employment, and that of one's relatives. Even the act of registration was no longer just a parochial affair, with state-appointed inspectors poised to swoop on any inconsistencies in the paperwork and report back to the central authorities. In Austria, if we consider what was accomplished even if just at the level of legislative discussions, we can see that what took more than seven years for the Italian fascists to put in place required less than three in Austria. Moreover, the Austrian legislative discussions in 1935 predated by a few years Nazi Germany's first population registration in 1938 and introduction of a national card index in 1939. 50 Therefore an examination of Austrian population politics in the interwar years needs to be placed in a larger context of European right-wing efforts to remake states and citizens on multiple levels: not just as mothers giving birth to soldiers, or programs for genetic breeding, which are the more commonly known spheres of population management in fascist states, but in the creeping legislation that sought to control society through controlling the mobility of the population and by declaring them members of the nation by way of a stamped piece of paper.

\section{ENDNOTES}

${ }^{1}$ I use citizenship and nationalism in the 'constructivist' sense of practices and processes, rather than the outcome-oriented and 'stages' approach of scholars such as Ernst Gellner and others, who explain divergences between ethnic-based and civicbased nationalism (and one could add citizenship) according to the various stages of industrialisation and cultural advancement of historically distinct groups of peoples and territories. Benedict Anderson's 1983 model of an imagined community is the best-known constructivist approach to nationalism, but see also Rogers Brubaker (2004, Ethnicity Without Groups, Harvard University Press, New York), which defines nationalism as 'a category of practice'.

2 For some of the more well-known attempts at synthesis and definition, see Payne, Stanley 1995, A History of Fascism, 1914-1945, UCL Press, London; Griffin, Roger (ed.) 1995, Fascism, Oxford University Press, Oxford; and Paxton, Robert 2004, The Anatomy of Fascism, Knopf, New York.

3 See Seton-Watson, Hugh 1966, 'Fascism, right and left', Journal of Contemporary History, vol. 1, no. 1, pp. 183-97; Rath, John and Schum, Carolyn W. 1980, 'The Dollfuss-Schuschnigg regime: fascist or authoritarian?' , in Stein Ugelvik Larsen, Bernt Hagtvet and Jan Petter Myklebust (eds), Who Were the Fascists?: Social roots of European fascism, Universitetsforlaget, Bergen. See also Rath's essays in Volumes 27-30 and 32 of Austrian History Yearbook (1996-99, 2001). 
Francis Carsten, the most eminent scholar of fascism in Austria, pioneered the two-pronged approach to fascism in Austria - that is, the view that the Heimwehr and the Nazi Party were two distinct fascist movements even if the regime itself was not fascist. See Carsten, F. L. 1977, Fascist Movements in Austria: From Schönerer to Hitler, Sage, London; and 1980, The Rise of Fascism, Second edition, Methuen, London. Gerhard Botz has also defined the Nazis and the Heimwehr as two 'brands' of fascism in Austria: the Nazis, representing 'national fascism' akin to German Nazism, and the Heimwehr, along with its close sibling, the Frontkämpfervereinigung (Front Veterans' Association), representing 'Heimwehr fascism'. The Christian Social Party and the Fatherland Front fall outside of the Austrian family of fascism in Botz's assessment and, after the Heimwehr wasabsorbed into the Fatherland Front in 1936, he concludes that the Heimwehr also ceased to be fascist.See Botz, Gerhard 1980, 'Varieties of fascism in Austria: introduction', in Stein Ugelvik Larsen, Bernt Hagtvet and Jan Petter Myklebust (eds), Who Were the Fascists?: Social roots of European fascism, Universitetsforlaget, Bergen.

4 See, notably, Kallis, Aristotle A. 2003, "Fascism”, "para-fascism" and "fascistization": on the similarities of three conceptual categories', European History Quarterly, vol.33, no. 2, pp. 219-49; and Mann, Michael 2004, Fascists, Cambridge University Press, New York.

5 For the 'Austro-fascist' school of historians, see Tálos, Emmerich and Neugebauer, Wolfgang (eds) 2005, 'Austrofaschismus': Beiträge über Politik, Ökonomie und Kultur 1934-1938, Fifth edition, Verlag für Gesellschaftskritik, Vienna; and Lewis, Jill 1990, 'Conservatives and fascists in Austria, 1918-34', inMartin Blinkhorn (ed.), Fascists and Conservatives: The radical right and the establishment in twentiethcentury Europe, Unwin Hyman, London, pp. 98-117; and 1991, Fascism and the Working Class in Austria, 1918-1934: The failure of labour in the First Republic , Berg, New York. More recently, Tim Kirk has argued that the conditions under which Austro-fascism came to power in the early 1930s were the same as in Germany and Italy. See Kirk, Tim 1996, Nazism and the Working Class in Austria: Industrial unrest and political dissent in the 'national community', Cambridge University Press, New York; and his article, 'Fascism and Austro-fascism', (2003, Contemporary Austrian Studies, vol. 11, pp. 10-31).

6 The trend since the 1980s emerging from the 'everyday life' school of West German historians (Alltagsgeschichte) has been to challenge to various degrees the thesis of top-down rule in the dictatorships of Nazi Germany, fascist Italy and Stalin's Russia. Some, like Victoria de Grazia in The Culture of Consent: Mass organization of leisure in fascist Italy
(1981, Cambridge University Press, Cambridge) and How Fascism Ruled Women: Italy, 1922-1945 (1992, University of California Press, Berkeley), and, more recently, R. J. B. Bosworth in Mussolini's Italy: Life under the dictatorship (2005, Penguin, London), have questioned the limits of consensus in daily life under the dictatorship. For most Italians, as Bosworth writes, 'everyday Mussolinism' did not equate with 'Fascist totalitarianism'. For others, notably Sheila Fitzpatrick, who coined the phrase 'everyday Stalinism' in her book Everyday Stalinism - Ordinary lives in extraordinary times: Soviet Russia in the $1930 \mathrm{~s}$ (1999, Oxford University Press, New York), men, women and families lived their lives daily within a Stalinist orbit or 'habitat' so much so that Stalin's Great Turn was less a 'revolution from above' than it was a 'revolution from below'. A new generation of historians schooled in these earlier approaches has begun to write the 'second chapter' of Alltagsgeschichte in the face of its seeming irrelevance to the new cultural history. See Steege, Paul, Bergerson, Andrew Stuart, Healy, Maureen and Swett, Pamela E. 2008, 'The history of everyday life: a second chapter', The Journal of Modern History, vol. 80, no. 2, pp. 358-78.

7 Studies of European population policies have focused mostly on Western Europe. See, for example, Quine, Maria Sophia 1996, Population Politics in Twentieth Century Europe: Fascist dictatorships and liberal democracies, Routledge, London. More recently, scholarship has also branched out to include Central and Eastern European regimes. See Turda, Marius and Weindling, Paul J. (eds) 2007, 'Blood and Homeland': Eugenics and racial nationalism in Central and Southeast Europe, 1900-1940, CEU Press, Budapest.

8 Cited in Ipsen, Carl 1996, Dictating Demography, Cambridge University Press, Cambridge, p. 88.

9 See Ipsen's review of his own book in 'Population policy in the age of fascism: observations on recent literature' (1998, Population and Development Review, vol. 24 , no. 3, p. 591).

10 On the value of 'relational' comparisons in European history - that is, historical comparisons that seek to use transnational approaches to explore the interactions and mutual influences between compared case studies - see Ther, Philipp 2003, 'Beyond the nation: the relational basis of a comparative history of Germany and Europe', Central European History, vol. 36, no. 1, pp. 45-73.

11 These dates correspond with the so-called Matteotti crisis, after the moderate socialist deputy and critic of the regime, Giacomo Matteotti, was murdered by a fascist gang in June 1924. The ensuing crisis involved a bungled investigation of the murder (the body did not turn up for two months), the prompt retreat of the majority of liberal parliament- 
ary deputies in what was termed the 'Aventine Secession' and finally, in early January 1925, Mussolini's announcement of his personal dictatorship. The year 1929 marked the final consolidation of the dictatorship's power with the Lateran Accords restoring church-state relations.

12 Ipsen, Dictating Demography, pp. 50-65.

13 Levi, Carlo 1947, Christ Stopped at Eboli, Translated by Frances Frenaye, Farrar, Straus, London, New York.

14 Ipsen, Dictating Demography, pp. 50-65.

15 Ibid., p. 65

16 Weindling, Paul 1988, 'Fascism and population in comparative European perspective', Population and Development Review, vol. 14, p. 104.

17 Ibid.

18 Ibid., p. 88.

19 Ibid., pp. 92-100.

20 Ibid., pp. 100, 196.

21 Ibid., pp. 64, 100, 118.

22 Ibid., p. 197.

23 Gini's theory, first presented at an international conference in Trieste in 1911, built on other prewar demographic theories that emphasised environmental factors, rather than social Darwinian ideas, in explaining the rise and fall of fertility. Gini developed the idea of differential fertility by which different classes in a nation reproduced at different rates. See Ipsen, Dictating Demography, pp. 45-6, 221-8.

24 On the press and propaganda merger in Austria, see El Refaie, Elisabeth 2002, 'Keeping the truce? Austrian press politics between the "July Agreement" (1936) and the Anschluss (1938)', German History, vol. 20, no. 1, p. 56. On Mussolini's patronage of the Heimwehr, see Kerekes, Lájos 1966, Abenddämmerung einer Demokratie: Mussolini, Gömbös und die Heimwehr, Europa Verlag, Vienna.

25 Österreichisches Staatsarchiv (ÖstA)/Archiv der Republik (AdR), Bundeskulturrat (BKA)/Heimatdienst (HD), Carton 6, Wiener Neueste Nachrichten, 23 June 1935.

26 The other three were the federal councils for the state, provinces and the economy. Members of these four councils made up the Bundesrat. See Jelavich, Barbara 1987, Modern Austria: Empire to republic, Cambridge University Press, Cambridge, pp. 203-4; Rath and Schum, 'The Dollfuss-Schuschnigg regime: fascist or authoritarian?', p. 251.

27 Österreichische Staatsarchiv (ÖStA), Archiv der Republik (AdR), 04R106/1-Bundeskulturrat, 18 September 1925.
28 The republic remained officially known as 'German-Austria' until the Allies insisted at the Paris Peace Conference in 1919 that the prefix 'German' be dropped.

29 For a discussion of the 1918 citizenship law and amendments under the Treaty of Saint-Germain, see Timms, Edward 1994, 'Citizenship and "Heimatrecht" after the Treaty of Saint-Germain', in Ritchie Robertson and Edward Timms (eds), The Habsburg Legacy: National identity in historical perspective, Edinburgh University Press, Edinburgh, pp. 160-1. On the effects of the legislation on the Jewish refugees in particular, see Grandner, Margarete 1995, 'Staatsbürger und Ausländer: Zum Ausgang Österreichs mit den jüdischen Flüchtlinge nach 1918', in Gernot Heiss and Oliver Rathkolb (eds), Asylland Wider Willen: Flüchtlinge in Österreich im Europäische Kontext seit 1914, J. and V. Edition, Vienna; and Hoffmann-Holter, Beatrix 1995, 'Abreisendmachung': Jüdische Kriegsflüchtlinge in Wien 1914-1923, Böhlau, Vienna, pp. 229-34.

30 Illigasch, Jürgen 1999, 'Migration aus und nach Österreich in der Zwischenkriegszeit: Bemerkungen zum Forschungsstand', Zeitgeschichte, vol. 26, no. 1, p. 14; John, Michael 1999, “'We do not even possess ourselves": on identity and ethnicity in Austria, 1880-1937', Austrian History Yearbook, vol. 30, p. 47.

31 Ibid.

32 Ibid.

33 Neue Freie Presse, 25 September 1935, p. 4.

34 Rathkolb, Oliver 1995, 'Asyl- und Transitland 1933-1938?', in Gernot Heiss and Oliver Rathkolb (eds), Asylland Wider Willen: Flüchtlinge in Österreich im Europäische Kontext seit 1914, J. and V. Edition, Vienna, pp. 109-11; Heiss, Gernot 1995, 'Ausländer, Flüchtlinge, Bolshewiken', in Gernot Heiss and Oliver Rathkolb (eds), Asylland Wider Willen: Flüchtlinge in Österreich im Europäische Kontext seit 1914, J. and V. Edition, Vienna, pp. 96, 99.

35 Ibid.

36 Neue Freie Presse, 25 September 1935, p. 4.

37 Rathkolb, Asyl-und Transitland 1933-1938, pp. 117-19.

38 On the German-nationalist press in Salzburg, for example, see Thorpe, Julie 2006, 'Provincials imagining the nation: pan-German identity in Salzburg, 1933-1938', Zeitgeschichte, vol. 33, no. 4, pp. 179-98. 39 Grazer Volksblatt, 1 January 1938, p. 3; 27 January 1938, p. 6.

40 Tagespost, 16 February 1937 (Abendblatt), p. 1.

41 See Wiener Neueste Nachrichten, 17 December 1937, pp. 1-2; 31 December 1937, pp. 1-2; 5 January 
1938 (Abendblatt), p. 1; 7 January 1939, p. 1; 1 February 1938, p. 1; 8 February 1938, p. 1.

42 Wiener Neueste Nachrichten, 31 December 1937, pp. 1-2.

43 Wiener Neueste Nachrichten, 19 December 1937, p. 4.

44 Wiener Neueste Nachrichten, 17 March 1936, p. 4.

45 Tagespost, 16 February 1937 (Abendblatt), p. 1.

46 Wiener Neueste Nachrichten, 17 December 1937, pp. 1-2.

47 Cited in Clare, George 1981, Last Waltz in Vienna: The destruction of a family 1842-1942, Macmillan, London, p. 158.

48 Ipsen, Dictating Demography, p. 90.

49 In France, where more than 1.5 million foreign workers had arrived by 1928, a law for the 'protection of national manpower' was introduced in 1926 to regulate the type and duration of work permits. The law had the immediate effect of reducing the number of foreign workers arriving annually in France from 162000 in 1926 to 64000 in 1927. See Singer-Kérel, Jeanne 1991, 'Foreign workers in France, 1891-1936', Ethnic and Racial Studies, vol. 14, no. 3, p. 287.

50 Weindling, 'Fascism and population in comparative European perspective', p. 110. 


\title{
ACTIVE CITIZENSHIP IN MULTICULTURAL AUSTRALIA
}

\author{
The Croatian experience
}

\section{VESNA DRAPAC}

This article addresses the relationship between multiculturalism, identity politics and active citizenship from the example of the history of Croatian settlement and Croatian associational or community life in Australia. My primary focus is on those Croats who arrived in the first two waves of post-1945 immigration because they represent the majority of Croatian-born in Australia and because there is a considerable amount of evidence (hitherto barely touched upon either by historians or by theorists of Australian multiculturalism) relating to this settlement experience and its impact on Australian civic life and identity.

My case study suggested the lived experience of Croatian association was a means by which individuals who had little education, poor English language skills and limited economic and professional opportunities exhibited an attachment to and an understanding of democratic processes and values in the pluralist society they had embraced as their own. This experience, in turn, contributed to their integration and, at the same time, to the retention of elements of their cultural background. In spite of arguments to the contrary, it also contributed to their peaceful coexistence with fellow Australians,
Yugoslav and non-Yugoslav, and to social cohesion. ${ }^{l}$

The example of Croatian associational life is not exceptional and much of what I argue may be usefully applied to other immigrant groups in Australia across the same period. ${ }^{2}$ The Croatian example, however, does stand out in some respects. It is instructive because, as this article shows, the history of Croatian communities in Australia presents us with a series of paradoxes that call into question some of the accepted stereotypes of Croatian behaviour in Australia. ${ }^{3}$ Further, the collapse of Yugoslavia and the ensuing wars of the 1990s enabled Croats in Australia to demonstrate their capacity to organise themselves and their local community structures on a global scale and provide the historian with the opportunity to observe the impact - locally, nationally and internationally - of their practice of active citizenship in the course of their daily lives. ${ }^{4}$ This article thus speculates on the effect of citizen engagement at the grassroots level on an evolving Australian identity and attempts, in part, to answer the question posed by Geoffrey Brahm Levey: 'How well does Australia allow immigrants to serve Australian democracy?' ${ }^{5}$ Finally, we will consider the ca- 
pacity of Croats in Australia to contribute to the future development and quality of Australian and Croatian civic life in the context of returns to Croatia (permanent and temporary) of members of the first generation and their Australian-born offspring.

Methodologically, my approach rests on the belief that close micro-studies of the history of the community engagement of immigrant groups from the inside out and from the bottom up provide an informed and nuanced understanding of the debates surrounding multiculturalism and citizenship in Australia. I will first discuss briefly the relevant points of contention in these debates and then outline the history of Croatian settlement in Australia in order to introduce my discussion of four paradoxes regarding Croatian community activism in Australia, which I believe warrant further reflection. The first of these paradoxes is that at a time when Croatian identity was not recognised in Australia and without government support, Croats displayed a high degree of initiative and flexibility in the establishment of community organisations. Second, Croatian women, overwhelmingly working class and poorly represented in formal Croatian structures, were active and visible in many aspects of associational life. Third, Croatian immigrants had low levels of education and low socioeconomic status but enjoyed success in their political lobbying for national recognition at the local, state and Commonwealth levels and attained a high degree of financial security relative to other immigrant groups and relative to the Australian population at large. Finally, whereas Croatia was not a sovereign state and one of the foundational tenets of Yugoslavism was that it would supersede or 'accommodate' south Slav nationalisms, Croats became known for their strong national identity.

\section{IMMIGRANTS AS CITIZENS}

Brian Galligan and Winsome Roberts argue that 'Australian citizenship is grounded in the everyday life of citizens and local communities'. 6 Broadly, I support this premise, but reject their claim that multiculturalism militates against the practice of Australian citizenship and against social cohesion and that it is potentially corrosive. Galligan and Roberts argue persuasively against Benedict Anderson's idea of the nation as an imagined construct and against minimalist conceptions of citizenship as grounded only in a set of laws or rights, universal and supranational, or 'anational'. Evoking Edmund Burke's 'little platoons' as the sites of the expression of civic identity and nationhood in its various guises, they suggest a middle way between triumphant and partial images of a monocultural Australian national identity and the (anarchic) cultural diversity of dogmatic multiculturalism, which, at its most radical, eschews the notion of a set of overarching commonly held Australian values in political, social and cultural life. Galligan and Roberts believe that Australia is not multicultural in the 'classic' sense and probably never was. 7 Rather, they argue that the provision of support for immigrant groups, especially those from non-English-speaking backgrounds, and the official promotion of tolerance for diversity and equal opportunity have facilitated a process of complete integration or 'transition' whereby the subsequent generations are 'thoroughly Australianised'. ${ }^{8}$ Referring to the various 
ways in which Australians have revealed their affinity with each other and with a set of political and ethical norms, Galligan and Roberts discuss voluntary associational life spanning the provision of medical services to remote rural areas to local selfhelp or environmental groups as an expression of active Australian citizenship in the microcosm. (Curiously, associational life along ethnic lines does not figure in this scenario even when the outcome is, as Galligan and Roberts argue, integration.) It would seem, then, that in opposition to the concept of multiculturalism as a fixed alternative to (an incomplete) vision of Australianness as white, male and British, 'transitional multiculturalism' is a catalyst for change. But the idea that multiculturalism has reached its 'use by' date is based on a superficial understanding of integration (defined largely in terms of rates of intermarriage in the second and third generations) and a product of the failure to acknowledge that citizen association along ethnic lines has contributed to the moulding of an evolving Australian identity. 9 While possibly nostalgic, even closed at times, ethnic structures have been responsive to change and have assumed some of the (positive) characteristics of the dominant culture to which their members freely and, generally, enthusiastically subscribed. Further, ethnic association has provided a vehicle for immigrants to experience the fullness of Australian civil society and active citizenship in communities that are familiar to them and which inspire trust, one of the preconditions of active citizenship and the formation of social capital. The earliest studies of ethnic associational life, even if generally sympathetic, labelled it as insular and thereby outside the parameters of 'Australi- an' or 'host' associational life and irrelevant to the practice of active citizenship. ${ }^{10}$ This tendency has persisted for the most part in the critique of multiculturalism and in general debates about citizenship and Australian identity. I reject the glaring double standard that allows for associational life emanating from 'Australian' circles to be inherently open and enriching to the wider community and ethnic activism, inherently insular and without benefits for anyone beyond the group in question. By definition, all associational life-'Australian' or 'ethnic' - is, at least initially, inward looking in the sense that it serves a prescribed set of interests.

The debate about the appropriateness of the term 'multicultural' in Australian public life is largely semantic and, apparently, irrelevant to a vast proportion of the population who endorse its general application. ${ }^{11}$ Critics of the term, alarmist or mild, are on occasion more theoretical or abstract than empirical in their observations of Australian multicultural practice. ${ }^{12}$ Alternatively, some use the concept of multiculturalism in their armoury as they deny the integrity of an Australian national identity and the existence of a set of core civic values to which Australians generally adhere, and as they pronounce the end of the era of nationalism or the advent of the 'post-national' world. But this position is just as extreme and largely untenable. A more reasonable position recognises that multiculturalism, grounded in the ideals of equity, access and social justice, among others, is also a vehicle for the practice of active citizenship, which, in all its diversity, contributes to the continuing evolution of an Australian identity. This identity is not weakened but is nourished by the activism evident in eth- 
nic association at the lowest level and among some of the least powerful members of the body politic.

\section{A BRIEF OVERVIEW OF CROATIAN IMMIGRATION PATTERNS}

Croats have been arriving in Australia since the mid nineteenth century. A large proportion of Croatian settlers in Australia came from areas along the Croatian coast and had lived with a long tradition of departures from their islands, towns or villages. It could be said that emigration was part of their historical memory and culture. The number of Croats present in Australia in the nineteenth century remained hidden as they were variously known as Austrians, Italians and 'S(c)lavonians'. 13 In Australia, Croats formed networks emanating from patterns of traditional family or chain migration but they also made connections with their co-nationals from regions much further afield than their local village or town. In nineteenth-century Australia, Croats travelled great distances to maintain contact with each other and celebrate important milestones in their lives from cradle to grave, including events such as marriages, christenings and funerals in what were, in essence, small Croatian communities. ${ }^{14}$ Croats arriving in Australia in the twentieth century continued to establish strong networks with each other. In the interwar period, they were known as and, indeed, referred to themselves as Yugoslavs. They were actively engaged in ethnic publishing ventures, musical and folkloric ensembles and featured prominently in labour activism, especially in mining communities in Western Australia and Broken Hill. ${ }^{15}$
All of the history of Croats in Australia since the end of World War I was mediated through the presence of a strong Yugoslav state, which, as the product of the collapse of empires in the wake of the Great War, became important strategically in international relations. The meaning of the word 'Yugoslav' was often contested. It was used differently by different people. For example, most 'Yugoslavs' in Mildura, Broken Hill and Kalgoorlie in the 1930s and 1940s were left-leaning or communist Croats, some of whom had left the Kingdom of Serbs, Croats and Slovenes because of its repressive politics. ${ }^{16}$ During World War II, Croats in Australia were involved in lobbying support for the Partisans led by Tito and complained to the Australian Government about the Yugoslav Consuls in Sydney and Perth because they were regarded as Serbian royalists and followers of the Chetnik resisters turned collaborators and their leader, Draža Mihailovi . 17 After 1945, these Croats and others among the immediate postwar arrivals still referred to themselves as 'Yugoslavs'. This was often to distinguish themselves from the stereotype of Croats as anti-communist and as supporters of the wartime collaborationists, the Ustaša, or of the political far right. ${ }^{18}$ This distinction between 'Croats' and Croatian Yugoslavs was constant through to the collapse of communist Yugoslavia in the 1990s and it is important to recognise that in the Australian Croatian context it related less to ideas about ethnicity and nationhood than to attitudes towards the Yugoslav state or simple political affiliation - of the Croats and their outside observers. 19

The post-1945 period saw a massive increase in the numbers of Croatian-born settling in Australia. They came in the first 
instance as displaced people or as refugees. Limited numbers also came on assisted passage, some after having crossed the Yugoslav borders illegally. Later, they arrived as 'economic migrants' and in accordance with the agreement reached between the governments of Australia and Yugoslavia in 1970. ${ }^{20}$ The definition of those departing Yugoslavia as 'economic migrants' in this second wave of post-1945 immigration was problematic from at least two perspectives: first, political factors governed the deteriorating social and economic situation in Yugoslavia in general; and second, those people who left often did so for a complex set of reasons-personal, economic, political and often, in the case of Croats, national — which made it difficult to demarcate strictly between economic and political migrants at that time. The numbers of Croatian immigrants dropped significantly from the 1980s. In spite of the fact that Australia received refugees from the wars of the 1990s, the total number of arrivals (many of whom were of a higher socioeconomic group) did not alter significantly the social makeup of the Croatian-born. 21

\section{A SERIES OF PARADOXES}

One of the common ways of viewing Croatian settlement in Australia emphasises conflict and division. This perception is often then offset by a defensive and inward-looking story of 'success'. Neither approach takes into account the range of Croatian immigrant experiences. Both approaches are one-dimensional and ahistorical, reinforcing stereotypes with recourse to the usual dichotomies (of class in particular). Each approach, in its own way, undervalues aspects of Croatian association that accommodate (rather than exclude) difference and have led to a sense of social cohesion, the accumulation of social capital and a strong affinity with Australian democratic processes. 22 (Interestingly, discussions on the link between social capital and active citizenship identify high socioeconomic status as one of the significant contributing variables, which may in part explain why the relationship between ethnic association and activism and social capital is largely overlooked.) ${ }^{23}$ In order to broaden the base of evidence on which we can draw to amplify our understanding of these important issues, we can identify the examples of and reasons for the emergence of a Croatian civic identity in the Australian context. An obvious way to do this is to look more closely at some of the features of association and activism that have hitherto been treated in only a cursory fashion or, indeed, thought to militate against cooperative social action and against integration. The four features or patterns of Croatian settlement I have chosen to discuss suggest ways in which Croats have mediated a reciprocal relationship between the old and the new, between maintaining elements of their ethnic identity and adapting to their changed circumstances, thereby exhibiting the qualities of active citizenship. Again, it is important to recognise that aspects of this discussion may apply to other immigrant groups, which also displaye high levels of engagement and voluntarism in the same time span.

The first point or paradox of note is that while for most of the period of Croatian immigration to Australia under review here there was no official acknowledgment of the settlers as ethnically or nationally distinctive, there was a high degree of 
community activism and political lobbying by Croats as Croats. This culminated in their recognition by the Australian Government as a distinct national and language group. ${ }^{24}$ Before ethnic and multicultural initiatives received financial aid - that is, before Australia embraced multiculturalism in the 1970s - Croats displayed a remarkable degree of flexibility, initiative and determination in setting up a range of structures to meet their social, cultural and welfare needs and did so without material or moral assistance from governmental agencies, either Australian or Yugoslav. They had no administrative or institutional support and relied on the voluntary work of Croats for their success. Thousands of individuals gave their time and skills freely in fundraising for the purchase of land on which they built halls, ethnic schools, sports centres and churches. In many regards, the achievements of the Croatian activists in South Australia stand as representative examples of the immigrants' resourcefulness in Australia as a whole. ${ }^{25}$ Approximately 6.9 per cent (3580) of Australia's Croatianborn live in South Australia. ${ }^{26}$ The first Australian 'Croatian club' was established in Adelaide in 1950 and others followed thereafter in capital cities and regional centres. Through sport, soccer in particular, Croats were able to find a social outlet and to have an impact on Australian sporting culture. The soccer team Adelaide Croatia, established in 1952, was the first of its kind in Australia, enjoyed a number of successes in the state league and still exists today. Adelaide is also home to the oldest continuously running Croatian ethnic school in Australia. ${ }^{27}$ In addition, there are folk ensembles and local programs in Croatian have been produced for
South Australian community radio stations since 1976. There are activities for elderly members of the community (as befits the ageing demographic of the Croatian-born) as well as an Australian-Croatian Chamber of Commerce. While several associations have existed in South Australia since the 1950s and 1960s, others, such as the writers' group, are recent initiatives and reflect the changing social landscape of community centres across the country. ${ }^{28}$ The range and intensity of this activity over several decades attest to a desire for broad social and cultural experiences and to the fact that these immigrants place a high value on participation in activities outside the home and workplace and whose benefits could not be quantified or are not measured in terms of direct (personal) material gain. 29 David Hogan and David Owen argue that there is a link between 'levels of social capital and levels of engagement in important citizenship practices, especially "voluntarist" practices within community organisations'. 30 Placing the example of immigrant voluntarist practices, not just that of Croats but of many other equally active groups, within this broader context presents us with a view that is different from the perspective of ethnic activism as 'closed' and amplifies our understanding of active citizenship. Moreover, privileging association as ostensibly more outward looking and more 'civic' purely on the basis that it emanates from the 'host' culture is, as we have seen, problematic on many counts.

The second point that invites reflection is the fact that while Croatian women are absent from most of the upper echelons of Croatian organisational structures, they have been remarkably active in community life. The Croatian women's contri- 
bution has generally been deemed a simple extension of traditional female pursuits or domestic duties and as such has not been studied seriously. However, as historians of gender have demonstrated, women who seem to be publicly 'absent' from communities in the past have in fact been active in many different aspects of social and cultural life through their sociability and networks grounded in their associational life. For a long time, the wider import of this 'hidden' history was neither understood nor seen to be something from which we could learn and this was especially the case for immigrant women in Australia. ${ }^{31}$

The raw facts on Croatian-born women in Australia would seem to confirm the findings of general studies of migrant women in the workforce that show they are generally unskilled and poorly paid. ${ }^{32}$ In Victoria, for example, Croatian women have traditionally been employed in textile industries, in light manufacturing plants and, on occasion, as seasonal farm workers. ${ }^{33}$ There is not much deviation from this pattern in other states, but Croatian working-class women have had a broader social engagement and have been more active than statistics about their employment history and levels of education might suggest. They established and ran ethnic schools and folkloric ensembles while also providing social support and caring for the welfare of their communities. ${ }^{34}$ Often, as intimated above, this activism reflected their traditional (gendered) role in Croatian families and the population at large, but it also reflected the kind of associational life not ordinarily identified with working-class women. ${ }^{35}$ Historians typically describe these as middle-class pursuits whereby women of a certain social standing who do not work outside the home draw on the kinds of skills gleaned in bourgeois households. ${ }^{36}$ The inherent class bias in analyses of Croatian women's lives needs to be redressed: their experience amplifies the received wisdom about migrant women in Australia and the evidence of women's organisational skills exhibited at the time of Croatia's war for independence (1991-95), for example, invites closer analysis.

During this war, Croatian women supervised large-scale aid projects and major fundraising events. They came to clubs and community centres after long hours of work, bringing their sewing machines with them. Having purchased hundreds of metres of material in bulk, they took to cutting it and sewing children's pyjamas, tracksuits, sheets and other items for dispatch in sea containers. They organised the collection of non-perishable foodstuffs for the victims of the war and the refugees. They purchased medicines and other necessities of life. They supported and continue to support orphans. ${ }^{37}$ These actions were the product of goodwill but also of a kind of self-actualisation made more visible by the special circumstances, to be sure, but prepared for over many years by the commitment to voluntarism and the (unstated) recognition of its social and psychic benefits. Anecdotal evidence suggests these values are generally not shared by the waves of immigrants arriving since the 1980s (especially in the wake of the collapse of Yugoslavia), who equate voluntarism with 'unpaid work'. A possible interpretation of this difference in attitude may be that there is no longer a need for such intense activism and that recent arrivals have greater scope to pursue a range of professional opportunities. However, one might also consider this at- 
titude a consequence of the erosion of civil and social life under communism and trace it to the perversion of the idea of voluntarism from the first years of communist implantation. In the aftermath of the destruction of World War II, brigades of youth 'volunteers' literally built the new socialist state through obligatory participation in construction programs. At the same time, the State did not tolerate 'social' or voluntary activities emanating from private initiatives (for example, church-run charitable work) because they were deemed inappropriate in a setting in which the State fulfilled its citizens' material needs. 38 Interestingly, the emergence of non-governmental organisations as representative of different interests in former communist states is often considered one of the markers of the relative health of the democratising process.

The third paradox, which is telling of the general and evolving social and civic experience of Croats, relates to the fact that post-1945 Croatian immigrants have a had very low socioeconomic status in Australian society and yet have been able to achieve a degree of fluency in political processes and lobbying combined with a high level of financial security. Furthermore, they placed a significant value on investing in community infrastructure and in what I referred to above as social capital. Theirs is an impressive financial and cultural legacy of community centres and structures across Australia for use by future generations. ${ }^{39}$ This is the case in spite of the fact that Croatian-born men and women are less educated and less socially mobile than their counterparts in the population at large. For example, in the 1990s, Croatian-born immigrants living in Victoria were less than half as likely to be employed as professionals than the Victorian population as a whole. ${ }^{40}$ Nevertheless, Croats, along with other Southern European settlers, do have a very high per capita rate of home ownership relative to the population at large. ${ }^{41}$ Their early postwar patterns of settlement in urban centres, common to many immigrants, whereby, for example, they moved from inner-city rented dwellings to their own homes either in established working-class suburbs or in newer housing developments, indicated a degree of economic stability and continuous employment. ${ }^{42}$ The almost complete absence of a professional cadre of Croatian teachers, public servants and white-collar workers relative to comparable immigrant groups invites us to consider the possibility of barriers existing to their social advancement over time arising from the slow recognition of Croats as an identifiable national group with specific needs. Significantly, while an obvious impediment in certain areas of social advancement and mobility, the absence of this professional cadre did not pose a barrier to the establishment of a range of Croatian community groups. One possible explanation for this is that Croats, feeling they had an inferior status vis-avis other 'Yugoslavs' and other immigrants, expended greater effort ensuring their community structures did well. 43 Their collective business acumen and their recognition of the need to plan for the long term have remained unexplored by historians who have interpreted their efforts (superficially) as narrowly nationalistic or insular. 44 Moreover, the more recent tendency to focus on Croatian business elites, on the obvious and highly visible - the millionaire ship-builder or the owner of the three-times winner of the 
Melbourne Cup, for example- has left a story that obscures the collective and individual experiences of the less spectacularly productive but nonetheless socially active Australian Croats. The greater emphasis on the outcomes rather than the process of immigrant community activism explains this imbalance as does the general absence of ethnic associational life from mainstream discussions about the relationship between active citizenship and the generation of social capital.

Finally, we had the paradox whereby Croatia was not an independent country but Croats in Australia were known for having a strong national identity. The partial explanation for this is that their high public profile was the product of their reaction against negative stereotyping. 45 One of their chosen methods of political lobbying - in group demonstrations and, where possible, near buildings housing Yugoslav consular staff or other official Yugoslav agencies-led to the conflation of all Croatian nationalist activism (anti-Yugoslavism) as potentially violent and rooted in the politics of collaborationism in World War II. This was the international framework for the teleological interpretation of all modern Croatian history and for the interpretation of the history of Central European and Balkan collaboration as exceptional. It was also the starting point for any analysis of Croatian émigré activities. This framework of interpretation persisted at least up to the fall of Yugoslavia, when some of the boundaries between Croats and Croatian 'Yugoslavs' became more blurred or disappeared. ${ }^{46}$ It is also true that the Yugoslav Government's attempt at discrediting Croatian activism by referring to it as 'extreme', 'fascist' or 'separatist' in inspira- tion as well as its crude attempts at 'neutralising' Croatian 'troublemakers' eventually lost its capacity to undermine Croatian communities as a whole, either in Australia or elsewhere. ${ }^{47}$ The reality of the situation meant that the media and government-manufactured Croatian 'type' was no longer sustainable because it was not rooted in the lived experience of Croats in Australia, or indeed the lived experience of Australians who came into contact with Croatian people. Croats did not exist in a vacuum nor were they simply reactive. They were contesting a negative and onedimensional interpretation of their identity and positing another in its place. At times, this led to a certain defensiveness on their part. ${ }^{48}$ On the whole, however, their reaction to the slurs against them led Croats (collectively) to be more outward looking: their behaviour was less 'conspiratorial' and 'nostalgic' than it was flexible, forward looking and adaptable. For example, a 'petrified' backward-looking community trapped in a time capsule could not have achieved what no other Croatian émigré community had achieved: official recognition of the integrity of the Croatian (as opposed to the so-called Serbo-Croatian) language, financial support for Croatian interpreting and translating services and Croatian language teaching in ethnic and public schools, and the establishment of the Croatian Studies Centre at Macquarie University in Sydney. The specific argument Croats had with the official use of 'Serbo-Croat' made their lobbying on this score distinctive.

\section{CONCLUSION}

It would be wrong to suggest that the story I have told relates uniquely or 
equally to all Croats in Australia or that theirs is a narrative of unequivocal success in terms of community relations and citizenship formation. However, this article has argued that superficial and essentialist observations about the Croats' predisposition to a certain kind of narrow and inward-looking nationalism are wanting in many respects. Events leading to the collapse of Yugoslavia were not precipitated by conspiratorial émigré 'separatists' but by the breakdown of social, political and economic life, the absence of social cohesion, a serious deficit of social capital and the collapse of communism in Europe. As is well documented, the fall of Yugoslavia occasioned a series of terrible wars of succession and great suffering. 49 Some feared that there would be unrest and violence among and between South Slav groups in Australia, but this did not eventuate. On the contrary, in their relief work, Croats drew on the skills of active citizenship they had acquired over many years from the model of their 'multicultural practice' in the microcosm of their clubs and social and religious centres. It could be said that it was understandable that they should embark on concerted action given the circumstances of the war. But as any student of the social history of modern warfare can testify, there is nothing inevitable about a 'united front' at times of crisis or in war. It seems reasonable to suggest that having negotiated their acculturation without compromising their multiple (mutually compatible) identities - ethnic, social, political and professional- Croats could now draw on their experience of decades of activism. They had pursued this activism in the face of indifference at best, and hostility at worst, and for the duration of the war managed vast shipments of aid in many forms as well as rallying moral and political support among the wider population for the cause of Croatian sovereignty.

The war of succession in Croatia was therefore a defining moment for regional and urban Croatian community life in Australia. It brought together, in concerted action, Croats from different centres including, for example, the Port Lincoln fishermen who donated tonnes of canned seafood. The experience of decades of intense associational life and voluntary activity for non-material gains schooled them and prepared them to manage aid on a substantial international scale. It was the persistent efforts of these Croats themselves to maintain a sense of national identity through language, music, sport and welfare work that ultimately produced a community that balanced the inward push to preserve their heritage and the outward pull towards integration. For example, many of the offspring of the Croatian-born who have successfully negotiated their dual national identities have founded, and now run, structures appropriate to the changed circumstances. These include, for example, the AustralianCroatian Chambers of Commerce. Such Australian Croats are also products of the socialisation experienced in the Croatian ethnic schools system. ${ }^{50}$ The formation of social capital, as we have seen, is linked to voluntary activity, which is 'socially patterned': family background is an important variable in adult civic participation. This suggests that if we look beyond the structures of ethnic association we may find a high predisposition towards active citizenship of the Australian-born offspring of immigrants who are engaged in their communities. 51 
Some have depicted Croatian immigrants arriving soon after 1945 and in the 1960 s and 1970s as incapable of accommodating multiple identities and more crudely 'nationalistic' than a later generation of educated immigrants who do not seek so much to 'preserve' Croatian identity or even distinguish themselves by it but to cultivate (personal) professional satisfaction and success. Possibly this dichotomous view is compromised by a superficial understanding of the dynamics at work in the established ethnic organisations and the limited data and small sample available in the study of recent immigrants. ${ }^{52} \mathrm{I}$ have argued that there is much of interest in the lives of the earlier waves of postwar Croatian immigrants to the historian of Australian multiculturalism, active citizenship and national identity. There is also much that the current Croatian Government could learn from the example of members of its most far-flung diasporic community, including those returning to their country of birth permanently or temporarily, as it prepares for its admission into the European Community. 53

We have seen that theorists of citizenship and multiculturalism note one important way of integrating minorities into the body politic is to foster strong ties across various social strata in a vigorous associational life that allows individuals and groups to promote their interests and participate in political life, conventionally and less conventionally defined, for the greater good. There is a long tradition of discourse on civic life along these lines. For example, the keys to the final (successful) implantation of republican and democratic values in France 80 years after the French Revolution of 1789 were a vigorous civic life evident across different regions and within different social groups. In France, women and men, separately or together, involved themselves in organisations ranging from those arguing for prison reform and agricultural progress to those sponsoring charitable ventures for the sick, the infirm and the outcast: there was not uniformity but a plurality of intentions and identities as people demonstrated their attachment to the centre through their intense activism at the local level. ${ }^{54}$ The Croats to whom I refer here may, indeed, have been 'anti-Yugoslav' but, predominantly, they expressed this through the positive affirmation of their identity as Australian citizens and through their legitimate desire to maintain aspects of their Croatian heritage, which was in turn tolerated and then nurtured in their new home. Overwhelmingly, their silent and hitherto unacknowledged contribution to social cohesion and to the presence of a robust Australian citizenry, inside their communal structures and within Australia as a whole, has remained hidden by the worn but well maintained fabric of their associational life.

\section{ENDNOTES}

1 One of the best examples of the way in which Croatian immigrants were typically portrayed may be found in Aarons, Mark 1989, Sanctuary. Nazi fugitives in Australia, William Heinemann Australia, Melbourne.

2 Several of my propositions could be applied to the other immigrant groups arriving in large numbers after 1945, but it is beyond the scope of this paper to embark on an extended comparative study.

3 Aarons, for example, writes of the 'massive' and 'credible evidence' amassed by the Australian Security Intelligence Organisation (ASIO) on (alleged) Croatian terrorist activity in Australia and routinely refers to faceless 'Croatian extremists' in Sanctuary. It was normal practice to conflate Croatian social and cultural activism with international terrorism and wartime collaboration. Possibly the lack of discrim- 
ination in the appraisal of Croatian association made it more difficult to identify who, precisely, was responsible for the series of bomb attacks on Yugoslav properties in Australia in the 1960s and 1970s. For a discussion of some of these issues, see Drapac, Vesna 2005, 'Perceptions of post-WWII Croatian immigrants: the South Australian case', Croatian Studies Review, vols 3-4, pp. 27-39.

4 David Hogan and David Owen have noted three measures of active citizenship as: the 'breadth of participation' in voluntary organisations; the amount of time devoted to voluntary organisations; and 'participation in political actions'. See their 'Social capital, active citizenship and political equality in Australia', 2000, in Ian Winter (ed.), Social Capital and Public Policy in Australia, Australian Institute of Family Studies, Melbourne, pp. 74-104.

5 Here Levey is turning on its head the question James Jupp raises in his 2003 publication, How Well Does Australian Democracy Serve Immigrant Australians?. Levey, Geoffrey Brahm 2008, 'Multiculturalism and Australian national identity', in Geoffrey Brahm Levey (ed.), Political Theory and Australian Multiculturalism, Berghahn Books, New York and Oxford, pp. 254-76.

6 Galligan, Brian and Roberts, Winsome 2004, Australian Citizenship, Melbourne University Press, Melbourne, p. xv.

7 By this they mean Australian immigrant groups from non-English-speaking backgrounds are not distinctive, mutually exclusive and self-perpetuating or entirely separate from the 'dominant Anglo-Australian mainstream'. They suggest that for most Australians multiculturalism means simply equality of opportunity and access as well as tolerance for cultural diversity. See their Australian Citizenship, p. 14 and Chapter 4. See also Levey, 'Multicultural political thought in the Australian perspective'; and Galligan, Brian and Roberts, Winsome 2008, 'Multiculturalism, national identity and pluralist democracy: the Australian variant', in Geoffrey Brahm Levey (ed.), Political Theory and Australian Multiculturalism, Berghahn Books, New York and Oxford, pp. 1-26, 209-24.

8 Galligan and Roberts, Australian Citizenship, pp. 5,14 . One of their key markers of integration is the successive generations' marriage outside the immigrant group.

9 James Jupp is critical of sweeping interpretations of integration as represented by statistics on intermarriage and the relatively careless use of intermarriage as a marker of the transitional nature of ethnic association and activism. He notes that there are numerous ways in which the second and third generations as well as Australia as a whole continue to be influenced and shaped by multiculturalism. See Jupp,
James 2008, 'A pragmatic response to a novel situation: Australian multiculturalism', in Geoffrey Brahm Levey (ed.), Political Theory and Australian Multiculturalism, Berghahn Books, New York and Oxford, pp. 225-41, 230-1.

10 The pioneering work of Jean Martin, for example, set the standard for assessing group organisation along ethnic or 'minority' lines in terms of its potential to engage outside or 'host' structures: 'Theoretically, ethnic associations might take upon themselves the role of socialising individual immigrants into the host society; like some therapeutic groups, their success might then be measured by their disintegration. No such function formed any part of the goals of ethnic community organisation in Adelaide.' See Martin, Jean I. 1972, Community and Identity: Refugee groups in Adelaide, The Australian National University Press, Canberra, p. 122. This position is also the background to the anti-assimilationist rhetoric of some elements in the multicultural lobby in its formative stages. See Lopez, Mark 2000, The Origins of Multiculturalism in Australian Politics 1945-1975, Melbourne University Press, Melbourne.

11 A poll conducted in 2005 found 80 per cent of Australians supported or strongly supported the policy of multiculturalism. See Markus, Maria R. 2008, 'Is Australian multiculturalism in crisis? A comment on Galligan and Roberts and on Jupp', in Geoffrey Brahm Levey (ed.), Political Theory and Australian Multiculturalism, Berghahn Books, New York and Oxford, pp. 242-55.

12 In Australian Citizenship, for example, Galligan and Roberts do not address ethnic association and focus largely on government policy and citizenship debates.

13 Šutalo, Ilija 2004, Croatians in Australia: Pioneers, settlers and their descendants, Wakefield Press, South Australia. Until recently, historians argued that only a handful of Croats had arrived in colonial Australia. Šutalo has found that at least 850 Croats had lived here before 1890. Graeme Hugo's research reveals that the number of returns, previously very low, is now higher than many would have anticipated before the collapse of Yugoslavia and it is reasonable to suggest that this is a consequence of Croatia becoming a sovereign state. Hugo, Graeme 2006, Migration and development: an Australian perspective on Croatia, Presentation to the Colloquium on Australian-Croatian Relations and the Role of the Diaspora, Croatian Club, Adelaide, 24 June 2006.

14 Šutalo, Croatians in Australia, passim.

15 See Marin Alagich and Steven Kosovich, 'Early Croatian settlement in eastern Australia', and Neven Smoje, 'Early Croatian settlement in Western Australia' (2001, in James Jupp [ed.], The Australian People. An encyclopedia of the nation, its people and 


\section{Active citizenship in multicultural Australia}

their origins, Cambridge University Press, Victoria, pp. 235-7, 241-3). See also Holjevac, Veceslav 1967, Hrvati izvan domovine, Matica Hrvatska, Zagreb, pp. 207-26.

16 The Communist Party was banned in the Kingdom of Serbs, Croats and Slovenes in 1921. Croats also experienced considerable economic and political hardship in the kingdom especially after the establishment of the royal dictatorship in 1929 and this situation often influenced their decision to emigrate. For an overview of the history of the kingdom, see Benson, Leslie 2004, Yugoslavia: A concise history, Palgrave Macmillan, Basingstoke, Chapter 3; and Ramet, Sabrina P. 2006, The Three Yugoslavias: Statebuilding and legitimation, 1918-2005, Woodrow Wilson Center Press and Indiana University Press, Washington, DC, and Bloomington, Ind., Chapters 2 and 3 .

17 See, for example, National Archives of Australia, A989/1943, 'Yugoslav Patriotic Fund for Yugoslav Forces and Refugees'.

18 Dr Ante Pavelic, leader of the émigré Ustaša ('insurgent') organisation, was installed by the Axis powers as the head of the so-called Independent State of Croatia, which was noted for its collaborationism and its exclusivist nationalist vision of an independent Croatia.

19 Some political divisions remained though there was less incentive for Croats to identify themselves as 'Yugoslavs' after Australia recognised Croatia as a sovereign state in 1992.

20 According to the 2006 Census, there are 50996 Croatian-born residents in Australia. See Australian Bureau of Statistics, 2006 Census of Population and Housing, Persons born in Croatia. The conservative estimate of Australians of Croatian ancestry is 105 747. See Hugo, 'Migration and development: an Australian perspective on Croatia'.

21 The total number of Croatian-born arriving before 1989 was 31 126. See Australian Bureau of Statistics, 2006 Census of Population and Housing, Persons Born in Croatia. Statistics from the Department of Immigration and Multicultural Affairs for 2001 show that the Croatian-born population is ageing. They also show that Croats are half as likely to have higher qualifications than the total Australian population although they are slightly more likely to have certificate-level qualifications and are 10 per cent more likely to have a trade. The majority (more than 70 per cent) are employed as skilled and semi-skilled labourers and tradespeople.

22 Statistics on citizenship in the 2006 Census show that almost all Croatian-born immigrants are naturalised: 48271 of a total of 50 996. See Australian Bureau of Statistics, 2006 Census of Population and Housing, Persons Born in Croatia. Galligan and
Roberts discuss the wider significance for civic life and Australian identity of immigrants choosing to take up citizenship in Australian Citizenship, p. 95.

23 Hogan and Owen, 'Social capital, active citizenship and political equality in Australia', pp. 95, 101.

24 Official recognition of Croats as a distinct national and language group occurred in 1980. The Croatian language was accepted as a Year 12 subject in New South Wales in 1981 and in Victoria in 1984. See Šutalo, Croatians in Australia, p. 222. See also Izbliza, Hrvati u Australiji (2005, Zagreb, pp. 48-50), catalogue of an exhibition curated by the Croatian Heritage Foundation in 2005.

25 Drapac, 'Perceptions of post-WWII Croatian immigrants'.

26 Hugo, 'Migration and development'.

27 This school recently celebrated its fortieth anniversary. See, Croatian Ethnic School Adelaide, 1966-2006 (2006, Adelaide), a pamphlet produced by the Croatian Ethnic School Adelaide.

28 Drapac, Vesna and Moran, Brendan 2004, Croatians in South Australia: History, culture, contribution, Brochure produced by the Croatian Community Council, Adelaide.

29 Šutalo has identified 280 Croatian centres and associations currently active in Australia. See Šutalo, Croatians in Australia, p. 217.

30 Hogan and Owen, 'Social capital, active citizenship and political equality in Australia', p. 75.

31 To an extent, it could be argued that the experience of immigrant women reflected the relative under-representation of women in general in aspects of Australian civic and professional life but that it magnified somewhat the gap between rights, community activism and access to positions of influence and power. See Galligan and Roberts, Australian Citizenship, Chapter 9, 'Women', pp. 185-200.

32 Data from the Victorian Department of Premier and Cabinet ('Select community profiles: 1996 Census', Multicultural Affairs Unit) confirm this. 33 Ibid.

34 For example, in Adelaide, the first Croatian ethnic school was established by a woman, Amalia Rutar, in the early 1960s. This school closed after a short time and another was established in 1966.

35 Hogan and Owen note the 'clear relationship' between 'socio-economic status and social capital formation' and between levels of social capital and levels of engagement in citizenship practices in 'Social capital, active citizenship and political equality in Australia', p. 95. The example of Croatian women offers a slightly different paradigm suggesting the 
variable of socioeconomic status is less important in certain instances.

36 See, for example, Perrot, Michelle (ed.) 1990, A History of Private Life. Volume 4. From the fires of revolution to the Great War, Translated by Arthur Goldhammer, Belknap Press of Harvard University Press, Cambridge, Mass., and London; and Prost, Antoine and Vincent, Gérard (eds) 1991, Riddles of Identity in Modern Times, Translated by Arthur Goldhammer, Belknap Press of Harvard University Press, Cambridge, Mass., and London, vol. 5.

37 Šutalo, Croatians in Australia, pp. 235-8. See also Izbliza, Hrvati u Australiji, pp. 51-3; and Drapac and Moran, Croatians in South Australia.

38 For a summary of the early period of communist implantation, see Lampe, John R. 1996, Yugoslavia as History: Twice there was a country, Cambridge University Press, Cambridge, Chapter 8. There is a vast literature on government-sponsored capillary associations introduced from above by fascist and communist states in twentieth-century Europe and their failure to generate enthusiasm for the ruling ideology across different professional and social groups. The general consensus among historians is that these structures promote mass conformism rather than self-actualisation.

39 Šutalo lists 43 Croatian-owned halls, clubs and sporting venues in Croatians in Australia, pp. 267-8.

40 See Note 19 for statistics on educational qualifications of the Croatian-born. There are probably more Croatian professionals in Victoria than other states.

41 See Victorian Department of Premier and Cabinet, 'Select community profiles: 1996 Census', Multicultural Affairs Unit.

42 Šutalo, Croatians in Australia, p. $211 \mathrm{ff}$.

43 Zlatko Skrbiš discusses aspects of the impact of such community activism on a sample of first and second-generation Croats and Slovenes in Long-Distance Nationalism: Diasporas, homelands and identities (1999, Ashgate, Aldershot).

44 This was particularly the case from the 1950s onwards, when ASIO reports routinely referred to Croatian 'fascists' and 'extremists' in an undifferentiated fashion. For an indication of the extent of ASIO's interest in Croats, see McKnight, David 1994, Australia's Spies and Their Secrets, Allen and Unwin, St Leonards, New South Wales. Commentators, including Mark Aarons, have tended to accept uncritically the information about Croatian community association contained within ASIO reports. The history of the political predilections - real and imagined - of Croatian organisations and of prominent Croatian individuals has yet to be written.
45 Kovacevic, Mladen and Gladovic, Mira 1990, Articles Regarding Croatians in Australia as Printed by 'The Sydney Morning Herald', Croatian Students Association of New South Wales for the Croatian Resource Centre, Sydney; Shaw, Les 1973, Trial by Slander, Harp Books, Canberra; and Drapac, 'Perceptions of post-WWII Croatian immigrants'.

46 See Stephen Clissold (1979, 'Croat separatism: nationalism, dissidence and terrorism', Conflict Studies, no. 103) for the classic articulation of this dichotomous treatment of Croatian nationalism outside Yugoslavia. Clissold served with the Military Mission to Yugoslavia during World War II and later at the British Embassy in Belgrade and became a prominent commentator on Yugoslav affairs.

47 Clissold discusses various attempts by Yugoslav secret agents to silence or 'neutralise' Croatian émigré opposition including assassinations, kidnappings and show trials (ibid., pp. 12-15).

48 This was especially true in the 1970s when Croatian communities were said to be harbouring alleged terrorists, when Australian security services infiltrated their organisations and with the wrongful arrest (in 1979) and conviction (subsequently overturned) of the so-called 'Croatian Six', accused of plotting to bomb the Sydney water supply.

49 See, for example, Gutman, Roy 1993, A Witness to Genocide, Element Books, Shaftesbury, Dorset.

50 The Croatian Government has largely failed to recognise the importance of this socialisation and of language education at the primary and secondary levels (in comparison with its commitment to the continuing endeavour at Macquarie University, for example). The lack of appropriate teaching materials for the rising generation of descendants of the Croatian-born immigrants (largely brought up in Englishspeaking households) remains a constant problem for teachers of Croatian language in Australia. See Croatian Ethnic School Adelaide, 1966-2006.

51 Hogan and Owen, 'Social capital, active citizenship and political equality in Australia', pp. 91, 101.

52 See, for example, olic-Peisker, Val 2004-05, 'Australian Croatians at the beginning of the twentyfirst century: a changing profile of the community and its public representation', Croatian Studies Review, vols 3-4, pp. 1-26.

53 The notion of the transmission of social capital and the idea that the 'skills' gained from civic engagement are mobile are rarely addressed in discussions about the relationship between Croatia and its diaspora. The most pressing concerns relate to narrowly economic questions - such as investment opportunities - and welfare policies touching on pensions and medical insurance. A deeper understanding of the 


\section{Active citizenship in multicultural Australia}

impact of the community association of ethnic groups may stimulate more debate on this subject.

54 This process is evocatively illustrated by Philip Nord in The Republican Moment: Struggles for democracy in nineteenth century France (1995, Harvard University Press, Cambridge, Mass.). 



\title{
CITIZENSHIP AND INTEGRATION
}

\author{
A snapshot of the Polish migrant community in Australia
}

\section{STEFAN MARKOWSKI}

\section{INTRODUCTION}

Australia has long been regarded as a country of immigration. In 1901, 23 per cent of Australians were born overseas. ${ }^{1}$ This share of overseas-born declined to 10 per cent in 1947, but grew again to reach 23 per cent in $1995 .{ }^{2}$ Since World War II, Australia's population has grown quickly due to a combination of high fertility and high net overseas migration (immigration less emigration). ${ }^{3}$ In the 2006 Census, 4.4 million people, more than onefifth of the total population, stated that they were not born in Australia. ${ }^{4}$ The 2001 Census of Population showed that 3.5 million people born in Australia (26 per cent of the total population) had at least one parent born overseas and nearly half of these had both parents overseasborn. ${ }^{5}$ If all those Australia-born with at least one parent born overseas were defined as second-generation immigrants, then by the end of the past century, nearly half of all Australians were either first or second-generation immigrants.

The structure of immigration and, thus, the composition of the overseas-born resident population have changed significantly over time. In the early days of Federation, the White Australia Policy ensured that immigrants were mostly of European origin and predominantly Anglo-Celtic. ${ }^{6}$ In the aftermath of World War II, shortages of labour prompted a change in policy and Australia accepted about 300000 displaced persons (DPs) from Eastern Europe. ${ }^{7}$ Further policy relaxation was aimed at attracting settlers from other parts of western and northern Europe, from southern Europe (in the 1950s) and Eastern Europe and the Middle East (1960s). ${ }^{8}$ The White Australia Policy was gradually relaxed throughout the 1960s and completely dismantled by the 1970s. Since then, the proportion of immigrants of nonEuropean origin, especially from Asia, has grown.

Of the overseas-born population, the United Kingdom continues to be the main migrant source country, accounting for 24 per cent of all overseas-born in 2005. New Zealanders were the second-largest group (9 per cent) and their number had trebled in the past 30 years. Italy was the third migrant source country ( 5 per cent) followed closely by China (4 per cent). The China-born group has increased nearly eightfold since 1981. ${ }^{9}$ On the other hand, between 1996 and 2006, of the 50 most common countries of birth, Poland, Hungary and Italy-born groups have recorded 
the largest absolute declines: on average, down 2 per cent per annum. 10

Australian citizenship is especially attractive for those immigrants whose international mobility has been impeded by onerous entry and exit visa requirements (particularly former displaced or 'stateless' people). Not surprisingly, DPs and immigrants from former Soviet-bloc countries (for example, Poland) have had high rates of take-up of Australian citizenship (see below). On the other hand, New Zealand and UK-born residents have been less inclined to take up Australian citizenship (38 per cent and 66 per cent respectively) even though they account for the highest number of new citizens in absolute terms. ${ }^{11}$ Also, as it is difficult and costly to renounce previous citizenship, a large proportion of immigrants who became Australian citizens by naturalisation or marriage are likely to have retained their home country citizenship. However, surprisingly little is known about the dual citizenship of Australian nationals and there is little systematic information about the extent of migrant identification with 'Australia'. 12

The Australian Bureau of Statistics (ABS) has long collected data on migrant communities in Australia. The Census provides regular snapshots of these communities and many of them have been profiled and analysed by the ABS and the research arm of the Department of Immigration and Citizenship (DIC, formerly DIMIA). Most of this research has focused on the extent of integration of migrant communities into the broader Australian society (for example, their English proficiency or propensity to take up Australian citizenship). Some data have also been collected on distinct ethnic and/or national characteristics of migrant communities (for example, their countries of birth, ancestries and languages spoken at home). Given the impact of immigration on the Australian social make-up and its significance for the national economy, it is important to know whether the process of immigrant absorption into the broader Australian community has been as effective as it might have been. Such knowledge has wide-ranging implications for immigration policies, in particular for the targeting of the most desirable migrant groups. There has also been much debate about conditions that have been and/or should be imposed on those resident immigrants who wish to become Australian citizens and the pros and cons of dual citizenship. The official statistics are incomplete in this respect and additional sources of data are needed to learn about the incidence and significance of dual citizenship and the extent of migrant identification with the broader Australian society.

In 2006, this author conducted a small survey of the Polish migrant community in Victoria, New South Wales, South Australia, Queensland and the Australian Capital Territory, mostly in the capital cities of these states, where 67 per cent of all Australians of Polish ancestry (about 110000 people) were reported to live. To access members of the Polish migrant community, the study solicited the help of the Polish Community Council of Australia and New Zealand Incorporated. In particular, it was assisted by the Polish Community Councils of New South Wales, Victoria, the Australian Capital Territory, Queensland and South Australia. ${ }^{13}$ The purpose of the survey was to probe the community's links with Poland, the likely impact of Poland's accession to the 
European Union on people's attitudes to Polish citizenship and the likelihood of reverse migration. A total of 1030 questionnaires were posted to people listed on various 'official' mailing lists and 335 completed questionnaires were returned by mail and processed by the research team (for a brief description of the sample, see the Statistical Annex). ${ }^{14}$ Although the size of the study was limited to 335 valid responses $(0.003$ per cent of all those who stated their ancestry as 'Polish' in the targeted area in 2006) and its findings were biased by exclusion of all those not connected to community councils, the survey yielded a wealth of information on various aspects of the 'Polishness' of the Polish migrant community. There also appears to be a strong concordance between its findings and data drawn from the 2006 Census.

This paper draws on general, censusbased information to profile Australians of Polish descent. The survey-based data are used to complement official statistics and, in particular, to shed some light on the dual citizenship of Polish migrants and the extent to which they identify with the broader Australian community. Four 'research questions' are implicit in this exercise:

1. What differentiates Australians of Polish extraction from the broader Australian community?

2. How well are they integrated into that community?

3. How many members of the Polish migrant community are dual citizens and what does it mean to be a dual citizen of Australia and Poland?

4. To what extent do Australians of Polish extraction identify with Australia and/or Poland?
While the absorption of Polish immigrants into the broader Australian community should not be taken as representative of all such adaptive processes, it is nevertheless instructive to consider the experience of a particular group that has blended successfully into the host community and the extent to which Polish migrants and their descendants have retained their ethic distinctiveness and, in particular, their Polish citizenship.

The paper is organised as follows. The first section introduces the evolving concept of citizenship in Australian and the related debate about the implications of citizenship policy for migrant integration into the broader Australian community. Next, we review 'measures of migrant distinctiveness': these are concepts used to differentiate migrant groups from the broader Australian population (for example, country of birth, stated ancestry and language spoken at home). This is followed by a description of Polish migration to Australia, which examines migrant inflows and outflows and general characteristics of Polish settlers in Australia. The next section focuses on the changing characteristics of Australian residents of Polish ancestry. Finally, citizenship and national identity are discussed: this section draws extensively on the Polish survey data. The paper concludes with a summary response to the four research questions.

\section{CITIZENSHIP AND INTEGRATION}

The concept of 'Australian citizenship' is a relatively recent one, having its origins in the Australian Citizenship Act 1948 (Commonwealth). Before the inception of 
the act on Australia Day in 1949, Australians were British subjects. ${ }^{15}$ And, until 1 May 1987, when the Australian Citizenship Amendment Act 1984 (Cth) came into force, 'Australia resisted the move to create a distinct Australian citizenship outside of British subject status' and Australian citizens continued to be both Australian nationals and British subjects. ${ }^{16}$ The 1948 Citizenship Act was also inequitable in that it allowed, de facto, overseas-born people to retain their former citizenship when granted Australian citizenship, while its Section 17 mandated its loss for an Australian citizen who acquired a citizenship of another country. Consequently, dual citizenship was accepted as a matter of legal reality for those who had another citizenship before becoming Australian citizens. As many countries make it difficult for nationals to renounce their citizenship, pledging allegiance to Australia upon becoming Australian citizens was insufficient to divest immigrants of their former citizenship. ${ }^{17}$ This inequity was finally removed in 2002 when amendments to Australian citizenship legislation made it possible for Australian nationals to acquire citizenship of another country, when previously it would have meant forfeiting their Australian citizenship. In 2007, a new Australian Citizenship Act was introduced, which repealed the contentious s. 17 and broadened citizenship provisions to include dual citizenship. Thus, the act has made it possible for Australian citizens to maintain their former citizenships or acquire a new one without fear of losing their Australian citizenship. 18

A further amendment was also introduced in 2007 to allow formal testing of prospective citizens' English language proficiency and civic knowledge. The amendment requires prospective Australian citizens to demonstrate their commitment to 'Australia's common values' and basic 'knowledge of Australia'. A review commissioned by the Rudd Government in 2008 found the test 'flawed, intimidating to some and discriminatory' in that it resembled a general knowledge quiz that required the knowledge of 'obscure historical or sporting facts'. 19 Not surprisingly, some migrant groups have contested the 'prescribed' notion of Australian identity as an attempt to homogenise the inherently hybrid migrant community. ${ }^{20}$ Nevertheless, this uniform national identification will continue to be tested, albeit in a modified form, as ' $[\mathrm{t}]$ he Rudd Government is committed to the citizenship test' that 'encourages potential citizens to find out more about Australia and understand the responsibilities and privileges of citizenship'. 21 More importantly though, the amendment highlights the duality inherent in the concept of 'Australian citizenship': those born into it may have little commitment to Australian values and a very limited knowledge of Australia, even though they are obliged to vote, while those seeking citizenship-by-grant have to demonstrate their eligibility for the membership of 'Club Australia'. As Kim Rubenstein points out:

If the Government expanded its thinking about citizenship policy for all Australian citizens, not only those seeking out Australian citizenship and indeed considered moving the portfolio of citizenship outside of the Immigration department, it would promote a greater attention to thinking through what is meant by membership of the Australian community. ${ }^{22}$ 
Elsewhere in this volume, Nolan and Rubenstein argue that a uniform national identification implied by the amended 2007 act sits uneasily with the legal acceptance of dual citizenship in the 2007 act. They also argue that in a hybrid society such as Australia, people should be free to assume a blended, complex identity rather than be expected to fit into a common social mould imposed by the country's dominant ethnic group. This writer is not qualified to discuss the extent to which the legal acceptance of dual citizenship is compatible with the uniform national identification implicit in the admittedly ill-conceived and insensitively implemented citizenship test introduced by the Howard Government in 2007. In logic, a degree of 'uniform identity' is implicit in laws about Australian citizenship that differentiate rights and obligations of Australian citizens from those of non-citizen residents of Australia and citizens of other countries. And, regardless of how this uniform identity is determined in practice and embodied in successive pieces of legislation, the membership of club Australia inevitably restricts members' freedom to assume a blended, complex identity of their choice. ${ }^{23}$ While the acceptance of social 'diversity' and 'hybridity' implies a broad interpretation of 'uniform identity' (as opposed to a common social mould imposed by the country's dominant ethnic group), no national 'club' is ever diverse and hybrid enough to satisfy all those who demand citizenship rights but resent the notion of reciprocal social obligations.

The 2007 test notwithstanding, membership requirements of Club Australia have been quite liberal by international standards and barriers to entry not partic- ularly high. ${ }^{24}$ This is best demonstrated by the proportion of overseas-born in the total population (about one-fifth) and the proportion of immigrants who acquire Australian citizenship. Since 1949, more than three million overseas-born Australian residents have acquired Australian citizenship and, in 2001, 74 per cent of overseas-born Australian residents (of two years or more) were Australian citizens. ${ }^{25}$ Also, of 3.7 million overseas-born people who responded to the 'ancestry question' in the 2001 Census, 76 per cent stated their citizenship as 'Australian' and only 23 per cent as 'Other'. ${ }^{26}$

\section{MEASURES OF MIGRANT DISTINCTIVENESS}

Country of birth differentiates those born overseas from those born in Australia. While the concept of 'overseasborn' population is relatively straightforward - that is, it refers to those residents of Australia who were not born in Australia ${ }^{27}$ - that of 'country of birth' is often ambiguous. For example, the postWorld War II boundary changes in Europe have made it difficult to determine the country of birth of many displaced persons. 28 Not surprisingly, boundary changes and the resultant population displacement make concepts such as 'country of birth' and 'nationality at birth' highly contentious. ${ }^{29}$ The ABS approach to these issues is to code people to the country they name as their country of birth - that is, 'all persons who give their country of birth as "Poland" are coded to Poland' and 'Birthplace responses which relate to particular cities or regions which are now in one country, but which may have been in another country at the time of birth, 
should be coded to the country, the city or region is in at the time of collection of the data. For example, the response "Danzig" should be coded to Poland not to Germany.' 30 Thus, a person born in the pre-1939 Polish city of Lvov who lists 'Poland' as his/her country of birth is coded as 'Poland-born' while those who are ethnically Polish but give Lvov as their city of birth are coded 'Ukraine-born'. Similarly, not all those Poland-born are ethnically Polish. In 1986, 84.7 per cent of Poland-born residents of Australia stated their ancestry as Polish, 7 per cent described themselves as Jewish, 1.7 per cent German, 1.5 per cent Ukrainian and 4.2 per cent 'Other'. 31

Concepts such as ancestry and ethnicity may also be used to identify migrant groups within the broader Australian population. In the census, ancestry is selfdetermined. ${ }^{32}$ But, the concept of 'ancestry' is even more ambiguous than that of 'country of birth'. A person may also have more than one ancestry. ${ }^{33}$ The concept of ancestry also depends on how it is probed in terms of past generations. For example, the 2001 Australian Census asked respondents to consider their ancestry as far back as three generations. ${ }^{34}$ Thus, a person's perception of 'ancestry' may not depend only on where he/she was born but on their nationality, country (or countries) of birth of their parents, language spoken at home, religion and numerous cultural factors. For example, one of our survey respondents described his/her identity as 'by birth: Canadian; by citizenship: Australian; by parentage: AngloPolish; by culture: Polish; and by upbringing: European'. In 2001, the most commonly stated ancestries in Australia were Australian (38 per cent of respondents),
English (36 per cent), Irish (11 per cent), Italian ( 5 per cent), German (4 per cent), Chinese ( 3 per cent) and Scottish (3 per cent). ${ }^{35}$ Polish ancestry was stated by 150 900 respondents ( 0.9 per cent). ${ }^{36}$ The 'revealed ancestry' also depends on how the population at large feels about various national groups and, thus, a person's willingness to reveal their ancestry. Consequently, a person's 'stated ancestry' may change over time. ${ }^{37}$

In the 2006 Census, nearly 164000 people stated their ancestry as Polish while more than 52000 gave Poland as their country of birth (see Table 5.1). ${ }^{38}$ Although those of Polish ancestry were the thirteenth-largest ancestry group, this was, to use a sporting analogy, only the 'fifth division' in the 'ancestry league' with the 'first division' English ancestry group numbering 6.4 million people and the 'fourth division' Greek ancestry group totalling 376000 people. And, while the number of Australians of Polish ancestry has increased over time, the number of Poland-born residents has declined (on average by 2 per cent per annum between 1996 and 2006).

English proficiency and the use of another language at home are also useful measures of migrant distinctiveness. The 2001 Census revealed that 2.8 million people (16 per cent of the Australian population) spoke a language other than English at home. ${ }^{39}$ This represents an 8 per cent increase since 1996 and reflects the growing multicultural make-up of the Australian population. It also reflects changes in the prevailing social climate, as, in contrast with the 1950s and the 1960s, migrants to Australia have recently been encouraged to retain their distinct ethnic and cultural identities. In 2001, the five most com- 
monly spoken second languages were Italian, Greek, Cantonese, Arabic and Vietnamese. Polish was the twelfth-most common 'other language', with 59000 people ( 0.3 per cent of the population) speaking it at home.

The propensity to speak the 'home country' language can also be used as a proxy for the ethnic distinctiveness of a migrant group, in particular when it is spoken by those born in Australia. But, as immigrants assimilate, successive generations tend to lose their command of the 'home country' language. For example, in 2001, 51 per cent of people speaking Greek at home were born in Australia, 43 per cent of those speaking Arabic and Italian were Australia-born, 40 per cent of those speaking Serbian and 39 per cent Macedonian. But only 20 per cent of Polish speakers were Australia-born, 15 per cent Dutch and 9 per cent German. ${ }^{40}$ In comparison with their Australian-Greek, Australian-Italian or Australian-Lebanese compatriots, the second generation of Polish immigrants appears to have lost a great deal of its language-related ethnic identity. Nevertheless, people may continue to identify with a particular ancestry or ancestries even if they no longer relate to their ancestral language, religion or culture.

In migrant communities, English language proficiency tends to be age related. For example, 88 per cent of the people aged under twenty-five who spoke a language other than English at home described their command of spoken English as good or very good, compared with 60 per cent of those aged sixty-five years and over. ${ }^{41}$ And 91 per cent of those born in Australia who spoke a language other than
English at home described their English as good or very good.

\section{POLISH MIGRATION TO AUSTRALIA}

\section{Two migrant waves}

When 'Polish-born' residents of Australia were first enumerated as a separate migrant group in 1921, the census tallied them at 1780 . Their number quadrupled by 1947 to reach $6573 .{ }^{42}$ After World War II, two distinct 'waves' of Polandborn immigrants arrived in Australia.

The first wave consisted of Polandborn displaced persons. Between 1947 and 1954, the Poland-born population of Australia increased more than eightfold to 56 594. The total population kept increasing, albeit at a decreasing rate, until the 1966 Census, when it peaked at 61641 people (see Table 5.1). It subsequently declined to 56051 in the 1976 Census.

The second wave of migrants started in 1980 and ended in the early 1990s. Between 1980 and 1985, 15570 Polish settlers arrived in Australia. This more than doubled the number of arrivals in the previous 15 years. ${ }^{43}$ In 1981-82, 5732 settlers arrived from Poland (the fourthlargest group of immigrants and nearly 5 per cent of all new arrivals). ${ }^{44}$ This rate of inflow continued in the second half of the 1980s. In 1989-90, the number of settlers from Poland increased to 8052 (nearly 7 per cent of all settlers and the fourthlargest group of immigrants). ${ }^{45}$ At the 1991 Census, the Poland-born population increased to 68496 people - an all-time high. 46 The inflow of Polish settlers decreased again in the 1990s: 3998 arrived in 1991-95 but only 1780 followed in 1996-2000. 47 
By the first decade of this century, the stream of arrivals of new settlers from Poland had decreased to a trickle: 2285 arrived in 2001-05 (0.0035 per cent of all immigrants to Australia during that period). ${ }^{48}$ In 2005-06, only 338 settlers arrived from Poland while 30407 arrived from Europe as a whole and 131593 in total. ${ }^{49}$ With the large decline in new arrivals and the natural rate of attrition, the number of Poland-born people decreased to 52256 in the 2006 Census (see Table 5.1). Not surprisingly, then, the Poland-born population has been one of those overseas-born groups that has recently recorded high rates of absolute decline: decreasing at 2 per cent a year. ${ }^{50}$

\section{GENERATIONAL CHANGE AND INTEGRATION}

Interestingly, this very small inflow of Polish settlers to Australia in the early 2000s occurred during a period of massive outflow (perhaps as many as two million people) of migrants from Poland. ${ }^{51}$ Settlers migrating to Australia are normally defined as those arriving with a permanent visa regardless of the intended period of stay. ${ }^{52}$ Those who departed Poland after the country's accession to the European Union largely fell into the 'grey' area of transnational job seekers rather than emigrants - that is, they were taking advantage of opportunities provided by the EU labour market enlargement rather than looking for a chance to leave Poland for good. 53 Nevertheless, we would expect the pull effect of 'chain migration' to be stronger - that is, the established community of earlier immigrants normally helps to attract further arrivals as the cost of settlement (to the settlers) is partially reduced through access to established ethnic networks and other intra-community support mechanisms. 54 The Australian labour market was also quite strong in the early and mid 2000s.

While Australia has long been perceived as a final destination of choice for international migrants, it appears to be increasingly harder to attract highly skilled immigrants. ${ }^{55}$ Global competition for skilled and adaptable migrants intensified in the 2000s, especially for the internationally mobile labour force seeking job opportunities that are not necessarily tied to permanent resettlement. ${ }^{56}$ Australia's traditional preference for permanent immigration may be unattractive to those seeking short-term job opportunities. The 'tyranny of distance' is also a factor likely to deter Eastern European job seekers when jobs are available in Western European labour markets since the EU enlargement. Clearly, as a migrant destination, Australia was not attractive enough to divert Polish migrants away from Europe in the early 2000s.

\section{REVERSE MIGRATION}

As G. Hugo observes, 'For most of the twentieth century the dominant paradigm in Australian international migration has been one of permanent settlement.' 57 Polish migrants fit well into this paradigm. By and large, the two waves of migrants arrived in Australia to stay and reverse migration has been negligible. Between 1996-97 and 2006-07, for example, permanent departures from Australia to Poland totalled 862 people, on average fewer than 80 people per annum. ${ }^{58}$ In 2005-06, 135 Poland-born people permanently departed from Australia, a very small num- 
ber considering that 67853 people permanently departed Australia during that period and only 88 of all those departing gave Poland as their intended country of residence. Of Poland-bound departees, 14 people were Australia-born and 74 overseas-born (but not necessarily Polandborn). ${ }^{59}$ In the early 2000s, the two-way flow of permanent migrants between Poland and Australia was negligible.

\section{SPATIAL DISTRIBUTION OF IMMIGRANTS}

Polish immigrants have largely concentrated in Victoria and New South Wales. In 1986, 36 per cent of Poland-born people (24 635) settled in Victoria (89 per cent of whom settled in Melbourne), 31 per cent (21 008 people) in New South Wales (80 per cent of those in Sydney), 12 per cent (7934) in South Australia (92 per cent in Adelaide), 10 per cent (6534) in Western Australia (81 per cent in Perth), 7 per cent (4854) in Queensland (69 per cent in Brisbane) and 2 per cent in Tasmania (1301) and the Australian Capital Territory (1275), respectively, with only 150 people settling in the Northern Territory. ${ }^{60}$ This broad pattern of settlement has largely continued to the present day, except that, in line with movements of the broader Australian population, the number of those living in Queensland has increased. With the decline of the Poland-born population, 'Polish ancestry' provides a better measure of the dispersion of Australians of Polish descent. At the 2006 Census, 32 per cent of Australians of Polish ancestry lived in Victoria (27 per cent in Melbourne), 28 per cent in New South Wales (21 per cent in Sydney), 13 per cent in Queensland (8 per cent in Brisbane), 11 per cent in South Australia (10 per cent in Adelaide), 11 per cent in Western Australia, 2 per cent in the Australian Capital Territory, 2 per cent in Tasmania and less than 0.5 per cent in the Northern Territory. ${ }^{61}$ In sum, Australians of Polish ancestry tend to be big-city dwellers with nearly half of the group living in Melbourne and Sydney conurbations.

\section{MIGRANT GENERATIONS}

Table 5.1 also includes estimates of different generations of Polish migrants. ${ }^{62}$ The first generation are Poland-born migrants (column a); the second generation comprises Australia-born people with one or both Poland-born parents; the third and subsequent generations are those with both parents Australia-born. The Polish identity of the second and subsequent generations of Polish migrants depends on the extent to which their members are prepared to state their ancestry as Polish. The second and third generations are shown in columns $\mathrm{c}$ and $\mathrm{d}$ in the table (no data are available for years before 1986).

As migrant streams age, the first generation of settlers decreases, mostly due to deaths, while the second and subsequent generations are normally expected to increase. In the early 2000s, the second generation of Polish migrants outnumbered the first generation. With the growing third, and soon fourth, generation of Australians of Polish ancestry, and no new arrivals from Poland to replace the loss of Poland-born settlers, the share of Poland-born in all those who claim Polish ancestry has declined and will continue to decline in the years to come (see Table 5.1, column f). 


\section{POLISH ANCESTRY}

About one-third of people of Polish ancestry also stated another ancestry, which suggests the relative 'openness' of the Polish settler community. ${ }^{63}$ The corresponding figures for Greek and Croatian communities are 21 per cent, Chinese 15 per cent, Macedonian 10 per cent and Vietnamese 6 per cent. ${ }^{64}$

Intermarriages provide another measure of the ability and willingness to melt into the broader host society. In 2001, 41 per cent of men and 38 per cent of women of the first generation of Polish migrants had a spouse of different ancestry. For the second generation, the corresponding figures were 83 per cent for men and 81 per cent for women, and for the third generation, 95 per cent for men and 94 per cent for women. ${ }^{65}$ In comparison, only 68 per cent of third-generation Greek men and 26 per cent of women marry someone of different ancestry. Intermarriages between those of Polish and Australian ancestry are also indicative of the extent to which different generations of Polish settlers have 'gone native'. In 2001, 8 per cent of men and 10 per cent of women of the first Polish generation married partners of Australian ancestry. For the second generation, the corresponding figures were 22 per cent and 19 per cent; and for the third, 13 per cent and 16 per cent. 66

\section{LANGUAGE SPOKEN AT HOME}

\section{English proficiency}

In 1996, the Bureau of Immigration, Multicultural and Population Research (BIMPR) introduced the concept of English Proficiency (EP) Country Groups. ${ }^{67}$ The EP index is defined in terms of migrants' (self-assessed) ability to speak English. EP1 is the highest level of deemed English proficiency (migrants from countries such as the United Kingdom, New Zealand, Ireland, Canada or South Africa) and EP4 is the lowest. In the 2001 Census, 57450 Poland-born people who answered the English proficiency question scored 87.6 per cent on the English proficiency scale, which ranked them as EP2. In five years before the census date, arrivals from Poland numbered 2038, and 1487 people spoke good English. This gave the recent arrivals the score of EP3 - that is, 73 per cent of them met the 'good English' criterion. 68

Overall, Poland-born Australians speak English relatively well. In the 2006 Census, 18 per cent of Poland-born people revealed that they speak 'English only' at home, 64 per cent speak 'other language' (mostly Polish) and very good or good English, and only 11 per cent stated that while they speak another language at home their English is poor. ${ }^{69}$ Proficiency in English appears to be more of a problem for the older Poland-born people who arrived in Australia relatively recently. For example, at the 1996 Census, of those aged sixty-five and above who arrived in Australia before 1986, 84 per cent claimed to be proficient in English. For those in the same age group who arrived between 1986 and 1996, only 34 per cent claimed to be proficient in English. 70

The census-based findings are supported by the results of the Polish survey: 17 per cent of survey respondents described themselves as 'native English speakers'. Of these, 60 per cent were aged twenty-twenty-nine, 24 per cent aged thirty-fifty-four and, somewhat surprisingly, 18 per cent aged over fifty-five. 
Australia-born native English speakers accounted for 66 per cent of the group, Poland-born for 18 per cent and elsewhere-born for 16 per cent. Further, 47 per cent of respondents described themselves as very proficient in English, 28 per cent as proficient, 5 per cent as not very proficient and 1 per cent as not at all proficient. ${ }^{71}$ Of those not proficient in English, 94 per cent were aged over fifty-five and all those with no English at all were over sixty-five. These numbers are similar to those drawn from 'official' statistics and confirm the relatively high level of English proficiency in the Polish migrant community. Of the 6 per cent of respondents whose English was poor, half considered themselves to be native Polish speakers and another quarter to be very proficient in Polish. And of the 17 per cent who are native English speakers, 63 per cent are also proficient or very proficient in Polish while 7 per cent claim to be native Polish speakers (completely bilingual).

\section{Polish proficiency}

Not surprisingly, given the tendency of Polish migrants to assimilate more easily than many other migrant groups, the ability to speak Polish as the 'second language' has declined in the second and subsequent generations. At the time of the 2001 Census, 40 per cent of those stating Polish ancestry spoke Polish at home but only 20 per cent of those born in Australia continued to speak it at home. ${ }^{72}$ This is a much smaller proportion than that for Greek, Italian or Arabic-speaking groups. Overall, the number of those speaking Polish at home peaked in the early 1990s, and has been declining since (see Table 5.1, column g).

The census does not probe the proficiency of those who speak Polish at home:
59 per cent of Polish survey respondents described themselves as 'native Polish speakers', 19 per cent stated they were 'very proficient' and 13 per cent were 'proficient' in Polish. Only 8 per cent described their command of Polish language as poor and 1 per cent as no Polish at all. Of those who stated their national identity as Polish (see below), nearly three-quarters considered themselves to be native Polish speakers, 22 per cent were very proficient Polish speakers and 4 per cent were proficient. Of those who stated their national identity as Australian, 27 per cent considered themselves as native Polish speakers, 16 per cent were very proficient in Polish, 22 per cent were proficient, 30 per cent were not proficient and only 5 per cent had no Polish at all. Some 89 per cent of native Polish speakers had parents speaking Polish at home, 95 per cent were born in Poland and 90 per cent spoke either Polish only or Polish and English at home. Also, 53 per cent of those who have lived in Australia for at least 20 years considered themselves to be native Polish speakers and another 21 per cent were very proficient in Polish. These surveybased figures suggest that regardless of their actual, as opposed to stated, command of the Polish language, Polish migrants appear to be very confident about their Polish language proficiency.

\section{RELIGION}

We have left out 'religion' as a factor differentiating the Polish community in Australia. While Poland is predominantly Catholic and Catholicism is the dominant religion of the Polish immigrant community in Australia, Poland-born Catholics accounted for less than 1 per cent of all 
those who stated their religion as 'Catholicism' $^{\prime}$ in the 2001 Census. ${ }^{73}$

\section{CITIZENSHIP AND NATIONAL IDENTITY}

\section{Australian citizenship}

In 1981, 85 per cent of Poland-born Australian permanent residents were Australian citizens. The proportion was about the same in 1986, although the number of Poland-born increased (see Table 5.1, columns a and h). In comparison with other overseas-born groups, these numbers are above average. ${ }^{74}$ With the recent slowdown in arrivals from Poland, relatively few Poland-born residents have acquired Australian citizenship in the past decade. 75

In 1981, 14 per cent of those who were Poland-born had 'other' (that is, nonAustralian) citizenship and a similar proportion had no Australian citizenship in 1986. ${ }^{76}$ In 2001, only 4171 (7 per cent) of Poland-born people had 'other' citizenship. ${ }^{77}$ However, it is very likely that many Poland-born people who have acquired Australian citizenship by marriage or naturalisation have also retained their Polish citizenship (see below). ${ }^{78}$ In Polish law, those born in Poland who have not renounced or been deprived of Polish nationality are deemed to be Polish nationals regardless of whether they are Polish passport-holders or not.

Some 323 Polish survey respondents (96 per cent of all) were Australian citizens, 10 were not ( 3 per cent) and two did not describe their citizenship. The proportion of Australian citizens in this sample is somewhat larger than that for the Polish community in Australia while the proportion of non-citizens is smaller. Of those respondents who were Australian citizens, 82 per cent acquired it through naturalisation, 12 per cent at birth and 2 per cent by marriage. ${ }^{79}$ Again, these figures are broadly consistent with the 'official' citizenship data that show high rates of Australian citizenship-by-naturalisation in the Polish migrant community.

\section{Polish citizenship}

The Polish survey complements official statistics in that it provides data on dual citizenship, in particular the dual Australian-Polish citizenship of respondents.

As expected, a large proportion of Polish survey respondents (66 per cent) has retained their Polish nationality and of these 94 per cent are Poland-born (see Table 5.2). Since 96 per cent of all respondents have Australian nationality, most of those who are Polish nationals are also dual Australian-Polish nationals. Only 3 per cent of Australia-born respondents are Polish nationals. And of those who are not Polish nationals (one-third of all respondents), 8 per cent have a third-country nationality (for example, British).

Polish passport-holders tend to include many of those dual nationals who are likely to travel to Poland. ${ }^{80}$ In the fiveyear period immediately preceding the survey, 80 per cent of Polish passportholders travelled to Poland at least once. Of those, 59 per cent of Polish passportholders visited Poland once or twice, 16 per cent three or four times and 5 per cent at least five times. After Poland's accession to the European Union, we expect a larger proportion of Polish nationals to acquire Polish passports as the possession of a valid Polish passport will make it easier to travel to, reside and work in all EU member states. 
Of those who are Polish nationals, 68 per cent are also Polish passport-holders (see Table 5.3) and 29 per cent are not. ${ }^{81}$ Polish passport-holders can be described as the de facto dual citizens as opposed to those who are dual citizens but who have no active involvement with Poland. Some 93 per cent of Polish passport-holders are Poland-born and only 4 per cent are Australia-born. However, only 21 per cent of Polish nationals vote in the Polish elections. ${ }^{82}$

\section{NATIONAL IDENTITY}

Polish survey respondents were also asked to state their 'national identity' (see Table 5.4), and 11 per cent of them described their identity as 'Australian', 33 per cent as 'Australian-Polish', 7 per cent as 'Polish', 44 per cent as 'Polish-Australian' and 4 per cent as 'Other'. ${ }^{83}$ Interestingly, half of those who described themselves as 'Australian' and 70 per cent of those 'Australian-Polish' were Polandborn. Nearly all (96 per cent) of those who considered themselves to be 'Polish' were Poland-born and only 4 per cent were born in Australia. Of those who stated they were 'Polish-Australian', 93 per cent were born in Poland and only 3 per cent in Australia. Surprisingly, of those aged twenty-nine or less, only one-fifth described themselves as 'Australian', nearly one-third as 'Australian-Polish', 11 per cent as 'Polish' and 26 per cent as 'PolishAustralian'. Those over thirty are more evenly spread across all identity groups compared with those over sixty-five.

\section{CONCLUSION}

Four 'research questions' were posed in the introduction to provide focus for this paper. I conclude by briefly responding to each of these questions.

Although the number of Poland-born Australian residents has been declining with deaths of first-generation migrants and insufficient new arrivals to replace them, ancestry data help to differentiate Australians of Polish extraction from the broader Australian community. The total number of those of Polish ancestry is increasing slowly as the second and third generations of Polish migrants replace Poland-born arrivals (see Table 5.1). There has been very little reverse migration, but the number of people speaking Polish at home peaked in the mid 1990s and only one-fifth of those born in Australia continue to speak Polish at home. Unless a new migrant wave arrives from Poland, those of Polish extraction will increasingly blend with the broader Australian community. Descriptors such 'country of birth' or 'language spoken at home' are less useful as a means of differentiating second and subsequent generations of migrants as ethnic groups intermarry and people reveal multiple ancestries.

Overall, Polish migrants have integrated well into the broader migrant community and appear to represent the type of migrant stream that Australian policymakers have tried to attract. This is reflected in particular in the ability of firstgeneration migrants to speak English as the second (and in some cases first) language. But, as is evident from the decline in new arrivals of permanent migrants from Poland in the 2000s, this type of migrant stream is becoming increasingly 
difficult to attract away from other host nations. This has major policy implications as the emphasis shifts from permanent immigration to policies aimed at attracting more mobile international job seekers.

The 2006 Polish survey provides new insights into the nature and incidence of dual citizenship. As expected, a large proportion of new Australian citizens have retained their previous (mostly Polish) citizenship. With Polish accession to the European Union, the propensity to retain or seek Polish citizenship is likely to increase for the second and third generations of Australians of Polish extraction. But, for many dual Australian-Polish citizens, the retention of Polish citizenship appears to be a matter of convenience (for example, the ease of travel to Poland and the European Union) rather than a commitment to Poland as a home country. For example, only one-fifth of Polish passportholders voted in Polish elections.

The latter point is further emphasised by the extent to which Australians of Polish extraction identify with Australia. Even though nearly 80 per cent of our survey respondents were Poland-born, 44 per cent of them described their national identity as 'Australian' or 'AustralianPolish' rather than 'Polish' or 'PolishAustralian'. Relative to some other migrant groups, Polish migrants have been more ready to embrace the uniform national identity of the host community.

\section{STATISTICAL ANNEX-POLISH COMMUNITY SURVEY}

Of 335 respondents in the Polish survey, 47 per cent were male, 50 per cent female and 3 per cent did not state their gender. One respondent was under nine- teen years of age, 19 (6 per cent) were aged twenty-twenty-nine years, 115 (34 per cent) were aged thrity-fifty-four, 92 (28 per cent) were aged fifty-five-sixty-four and 97 (29 per cent) were aged sixty-five and over. ${ }^{84}$ This age distribution was broadly similar to the age profile for the Poland-born community in the 2006 Census, of whom 5 per cent were under twenty-five, 42 per cent were aged twenty-five-fifty-four, 16 per cent were aged fifty-five-sixty-four and 37 per cent were over sixty-five. ${ }^{85}$

A total of 263 people in the sample were Poland-born (79 per cent), 41 (12 per cent) were born in Australia and 27 (8 per cent) were born in another country. 86 Table 5.Alshows the age distribution of respondents by their country of birth. The sample is more representative of the Poland-born population of Australia than of those of Polish ancestry, as only 32 per cent of Australians of Polish ancestry were born in Poland (see Table 5.1).

A majority (92 per cent) of respondents had their mother born in Poland and 90 per cent had a Poland-born father. Only 2 per cent had an Australia-born mother and 1 per cent an Australia-born father; 4 per cent had their mother and 6 per cent their father born in another country. Less than 1 per cent of the respondents had both parents born in Australia and 85 per cent had both parents born in Poland.

Three-quarters of the respondents had lived in Australia for at least 20 years and 18 per cent for between 10 and 19 years. This reflects the 'vintage' structure of Polish migrant inflows: the two major waves of Poland-born arrivals (1947-66 and 1980-91), with a very small inflow since the 1990s. Table 5.A2 shows the length of residence by the country of birth 
of respondents. Interestingly, 17 per cent of those who lived in Australia between only five and nine years were born in countries other than Poland or Australia.

Table 5.A3 shows the distribution of respondents by language spoken at home, their country of birth and age. Only 21 per cent of respondents speak 'English only' at home, 22 per cent speak 'Polish only' and 56 per cent are bilingual English-Polish speakers. Of those who speak only Polish, 93 per cent are Poland-born. However, those who speak only English are more likely to be born in Poland (54 per cent) than Australia (36 per cent). Polish-only speakers are concentrated in two age groups: thirty-fifty-four (32 per cent) and over sixty-five5 (35 per cent). English-only speakers are predominantly aged thirty-sixty-four and the bilingual group is spread quite evenly across all age groups. Of those who speak English only, 79 per cent have lived in Australia for at least 20 years and 10 per cent for 10-19 years. Also, broadly similar proportions characterise Polish-only speakers (69 per cent and 22 per cent, respectively). Of the bilingual group, 76 per cent have lived in Australia for at least 20 years and 20 per cent for 10-19 years.

Not surprisingly though, of those born in Poland, 82 per cent grew up in households where parents spoke Polish at home and only 9 per cent in households where both English and Polish were spoken by parents. Another 9 per cent had their parents speak a language other than Polish or English. Of those born in Australia, 5 per cent grew up in households where parents spoke only English and 51 per cent where they spoke only Polish. Some 44 per cent of Australia-born respondents had parents that spoke both English and Polish at home. 
Table 5.1 Australian residents of Polish ancestry

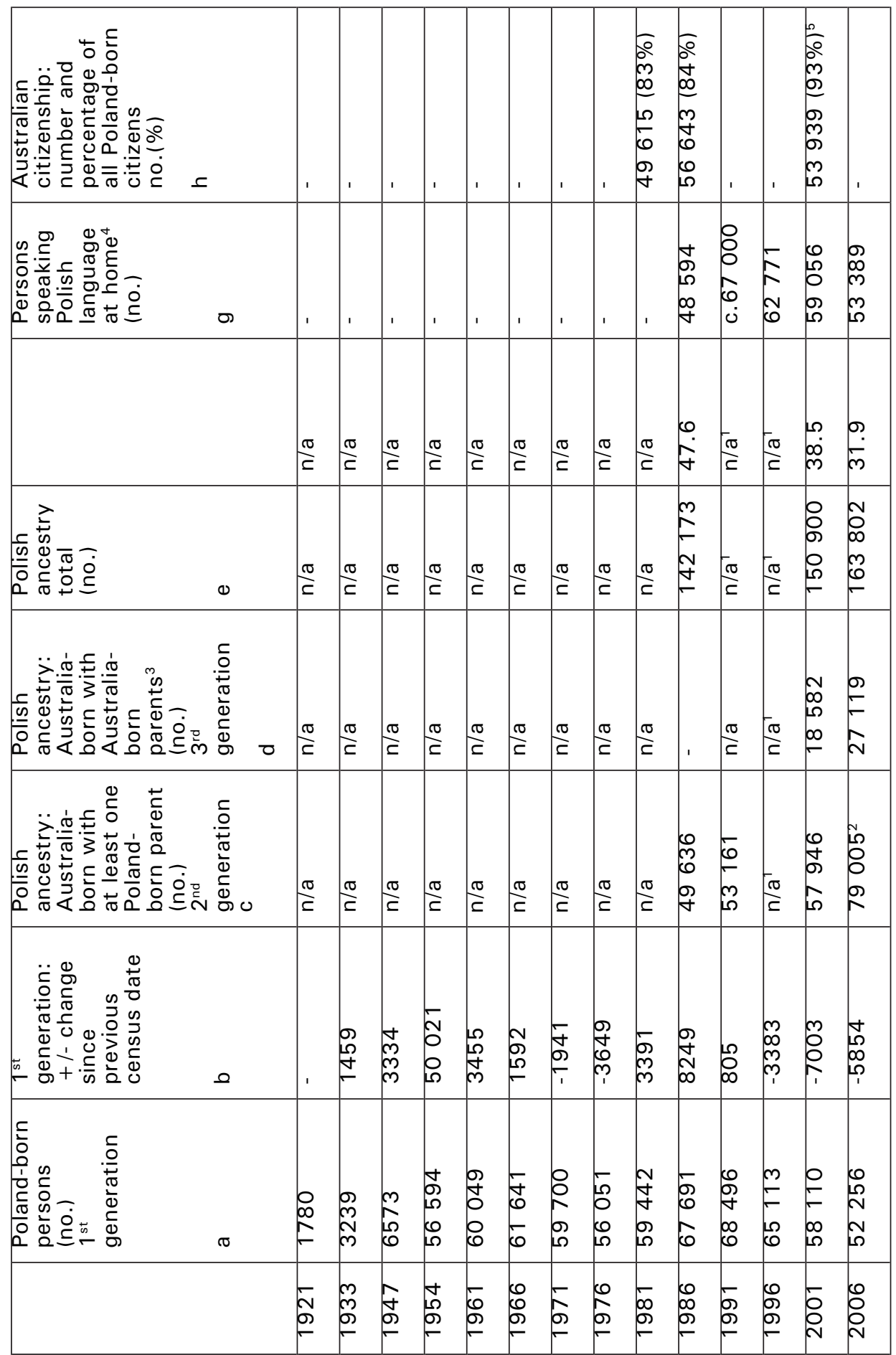


1 The 'ancestry' question was first asked in the 1986 Census but no ancestry data were collected in the 1991 and 1996 Censuses.

${ }^{2}$ For 2006, the second-generation estimate was obtained by subtracting Poland-born persons from all persons of Polish ancestry who had at least one parent born in Poland (that is, 133972 less 52256 less 2711; country of birth of either/both parents not stated). This is likely to be an overestimate of the second-generation total.

${ }^{3}$ This category represents third and subsequent generations of persons of stated Polish ancestry. Also, Polish ancestry means that at least one parent had Polish ancestry.

${ }^{4}$ These figures may be overstated as some Poland-born people who speak another language at home are not Polish speakers. However, changes over time - that is, the first increasing and then declining numbers of Polish speakers-re ect the declining proportion of first generation immigrants in all those claiming Polish ancestry. Figure for 1991 from Jupp, op. cit., Table 1.

${ }^{5}$ This figure has been calculated by subtracting those of Polish ancestry who stated their citizenship as 'Other' at the 2001 Census (4171 persons) from those who described themselves as Poland-born (column a).

Sources: For 1921-86: Bureau of Immigration Research 1991, Community Profiles Poland Born, Statistics Section, Bureau of Immigration Research, Canberra, Tables 1, 4 and 17; for 1991: Jupp, J. 1995, ‘Ethnic and cultural diversity in Australia', Year Book Australia, 1995, 1301.0-1/01/1995, Australian Bureau of Statistics, Canberra, Table 1; for 1996-2006: Australian Bureau of Statistics 2007, 2006 Community Profile Series, Cat. no. 2003.0, Australian Bureau of Statistics, Canberra, Tables T08-10; Australian Bureau of Statistics 2003, Australian Social Trends, 2003, 4102.0-03/06/2003, Australian Bureau of Statistics, Canberra, for second generation in 2001; and Australian Bureau of Statistics 2004, Year Book Australia, 2004, 1301.027/01/2004, Australian Bureau of Statistics, Canberra, Table A.2, p. 92. 
Table 5.2 Polish nationality by country of birth and age

\begin{tabular}{|c|c|c|c|c|c|c|}
\hline \multirow[b]{2}{*}{$\begin{array}{l}\text { Polish } \\
\text { nationality }\end{array}$} & \multicolumn{4}{|l|}{ Born in } & \multicolumn{2}{|c|}{ Respondents } \\
\hline & $\begin{array}{l}\text { Poland } \\
\text { (\%) }\end{array}$ & $\begin{array}{l}\text { Australia } \\
(\%)\end{array}$ & $\begin{array}{l}\text { Other } \\
(\%)\end{array}$ & $\begin{array}{l}\text { Not stated } \\
(\%)\end{array}$ & $\begin{array}{l}\text { Count } \\
\text { (no) }\end{array}$ & $\begin{array}{l}\text { Per cent of } \\
\text { respondents } \\
(\%)\end{array}$ \\
\hline No & 48 & 32 & 19 & 1 & 109 & 33 \\
\hline Yes & 94 & 3 & 2 & 1 & 220 & 66 \\
\hline Not stated & 75 & 0 & 0 & 25 & 6 & 1 \\
\hline Total & 79 & 12 & 8 & 1 & 335 & 100 \\
\hline \multirow[b]{2}{*}{$\begin{array}{l}\text { Polish } \\
\text { nationality }\end{array}$} & \multicolumn{4}{|c|}{ Age groups (years) } & \multicolumn{2}{|c|}{ Respondents } \\
\hline & $\begin{array}{l}<29 \\
(\%)\end{array}$ & $\begin{array}{l}30-54 \\
(\%)\end{array}$ & $\begin{array}{l}55-64 \\
(\%)\end{array}$ & $\begin{array}{l}<65 \\
(\%)\end{array}$ & $\begin{array}{l}\text { Count }^{\mathrm{a}} \\
\text { (no.) }\end{array}$ & $\begin{array}{l}\text { Per cent of } \\
\text { respondents }\end{array}$ \\
\hline No & 9 & 23 & 31 & 34 & 109 & 33 \\
\hline Yes & 5 & 41 & 26 & 26 & 220 & 66 \\
\hline Not stated & 0 & 25 & 25 & 50 & 6 & 1 \\
\hline Total & 6 & 34 & 28 & 29 & 335 & 100 \\
\hline
\end{tabular}

${ }^{a}$ This count also includes all those who did not state their age (11 people or 3 per cent of the sample). Thus, percentages in rows may not add up to 100 per cent.

Source: Polish survey.

Table 5.3 Polish nationality, Polish passport-holders and voters

\begin{tabular}{|c|c|c|c|c|c|}
\hline \multirow[b]{2}{*}{$\begin{array}{l}\text { Polish } \\
\text { nationality }\end{array}$} & \multicolumn{3}{|c|}{ Polish passport-holders (\%) } & \multicolumn{2}{|c|}{ Respondents } \\
\hline & $\begin{array}{l}\text { No } \\
(\%)\end{array}$ & $\begin{array}{l}\text { Yes } \\
(\%)\end{array}$ & $\begin{array}{l}\text { Not stated } \\
(\%)\end{array}$ & $\begin{array}{l}\text { Count } \\
\text { (no.) }\end{array}$ & $\begin{array}{l}\text { Per cent of } \\
\text { respondents }\end{array}$ \\
\hline No & 100 & 0 & 0 & 109 & $\frac{(\%)}{33}$ \\
\hline Yes & 29 & 68 & 3 & 220 & 66 \\
\hline Not stated & 0 & 0 & 100 & 6 & 1 \\
\hline Total & 52 & 44 & 4 & 335 & 100 \\
\hline \multirow[b]{2}{*}{$\begin{array}{l}\text { Polish } \\
\text { nationality }\end{array}$} & \multicolumn{3}{|c|}{ Vote in Polish elections (\%) } & \multicolumn{2}{|c|}{ Respondents } \\
\hline & $\begin{array}{l}\text { No } \\
(\%)\end{array}$ & $\begin{array}{l}\text { Yes } \\
(\%)\end{array}$ & $\begin{array}{l}\text { Not stated } \\
(\%)\end{array}$ & $\begin{array}{l}\text { Count } \\
\text { (no.) }\end{array}$ & $\begin{array}{l}\text { Per cent of } \\
\text { respondents }\end{array}$ \\
\hline No & 100 & 0 & 0 & 109 & 33 \\
\hline Yes & 65 & 21 & 14 & 220 & 66 \\
\hline Not stated & 0 & 0 & $100^{a}$ & 6 & 1 \\
\hline Total & 76 & 14 & 10 & 335 & 100 \\
\hline
\end{tabular}

a One person was a Polish voter but did not state his/her Polish nationality and has therefore been excluded from the group of Polish voters.

Source: Polish survey. 
Citizenship and integration

Table 5.4 National identity by country of birth and age

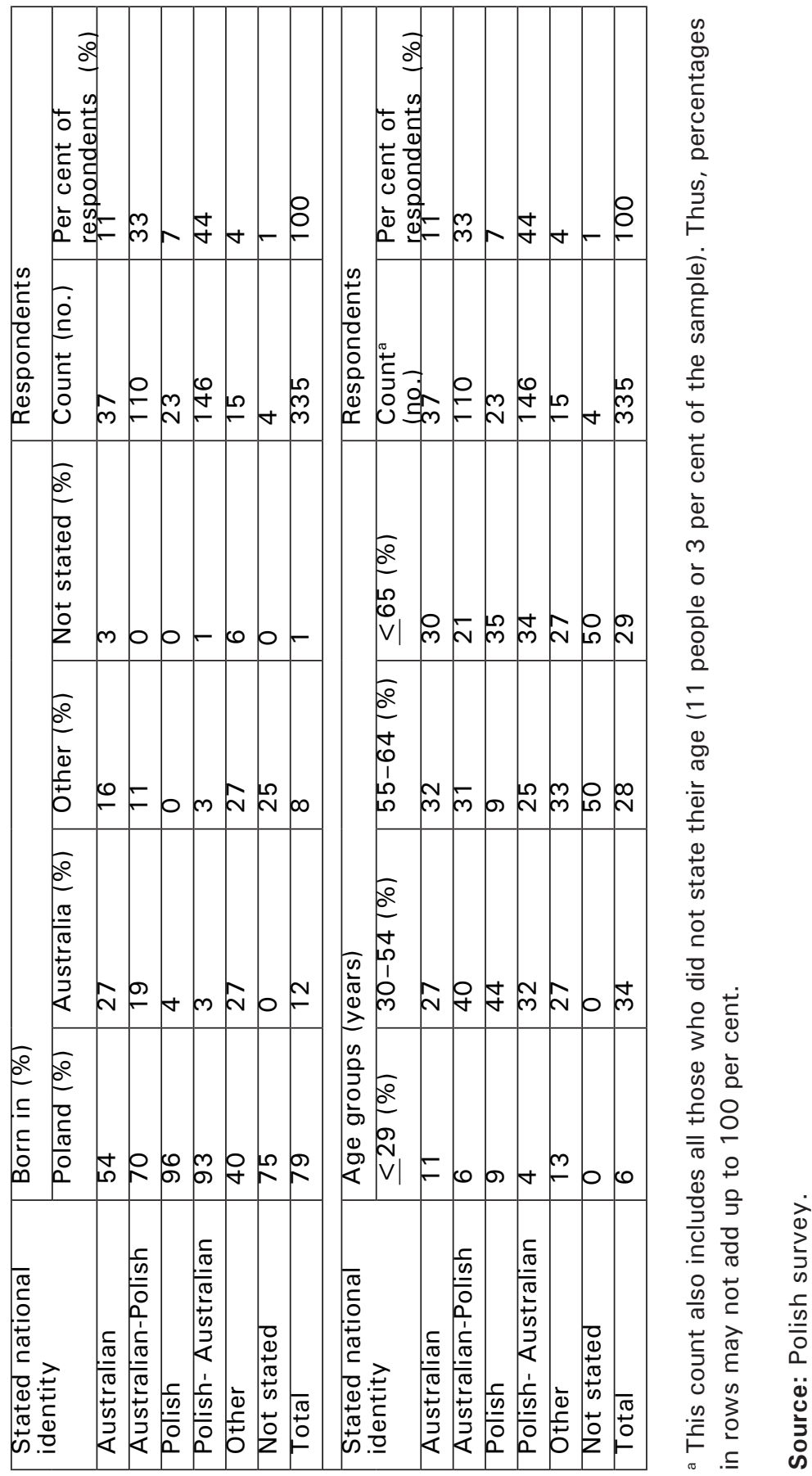


Table 5.A1 Country of birth by age group of sample respondents and country of birth of their parents

\begin{tabular}{|c|c|c|c|c|c|c|}
\hline \multirow[b]{2}{*}{$\begin{array}{l}\text { Age group } \\
\text { (years) }\end{array}$} & \multicolumn{4}{|c|}{ Survey respondent born in (\%) } & \multicolumn{2}{|c|}{ Respondents } \\
\hline & $\begin{array}{l}\text { Poland } \\
\text { (\%) }\end{array}$ & $\begin{array}{l}\text { Australia } \\
\text { (\%) }\end{array}$ & $\begin{array}{l}\text { Other } \\
\text { (\%) }\end{array}$ & $\begin{array}{l}\text { Not stated } \\
(\%)\end{array}$ & $\begin{array}{l}\text { Count } \\
\text { (no.) }\end{array}$ & $\begin{array}{l}\text { Per cent of all } \\
\text { responses }(\%)\end{array}$ \\
\hline $20-29$ & 53 & 37 & 5 & 5 & 19 & 6 \\
\hline $30-54$ & 77 & 19 & 3 & 1 & 115 & 34 \\
\hline $55-64$ & 72 & 11 & 16 & 1 & 92 & 28 \\
\hline 65 and over & 93 & 1 & 6 & 0 & 97 & 29 \\
\hline Not stated & 82 & - & 9 & 9 & 11 & 3 \\
\hline Total & 79 & 12 & 8 & 1 & $334^{\mathrm{a}}$ & 100 \\
\hline \multirow[b]{2}{*}{ Parent } & \multicolumn{4}{|c|}{ Respondent's parent born in (\%) } & \multicolumn{2}{|c|}{ Respondents } \\
\hline & $\begin{array}{l}\text { Poland } \\
(\%)\end{array}$ & $\begin{array}{l}\text { Australia } \\
(\%)\end{array}$ & $\begin{array}{l}\text { Other } \\
\text { (\%) }\end{array}$ & $\begin{array}{l}\text { Not stated } \\
(\%)\end{array}$ & $\begin{array}{l}\text { Count } \\
\text { (no) }\end{array}$ & $\begin{array}{l}\text { Per cent of all } \\
\text { responses }\end{array}$ \\
\hline Mother & 92 & 2 & 4 & 3 & 335 & 100 \\
\hline Father & 90 & 1 & 6 & 3 & 335 & 100 \\
\hline
\end{tabular}

a As there was only one respondent in the 'age under 20' group, this age group has been excluded from the table.

Source: Polish survey.

Table 5.A2 Length of residence in Australia by country of birth

\begin{tabular}{|l|l|l|l|l|l|l|}
\hline \multirow{2}{*}{$\begin{array}{l}\text { Length of } \\
\text { residence in } \\
\text { years }\end{array}$} & \multicolumn{3}{|l|}{ Born in $(\%)$} & \multicolumn{2}{l|}{ Respondents } \\
\cline { 2 - 7 } & $\begin{array}{l}\text { Poland } \\
(\%)\end{array}$ & $\begin{array}{l}\text { Australia } \\
(\%)\end{array}$ & $\begin{array}{l}\text { Other } \\
(\%)\end{array}$ & $\begin{array}{l}\text { Not stated } \\
(\%)\end{array}$ & $\begin{array}{l}\text { Count } \\
(\text { no.) }\end{array}$ & $\begin{array}{l}\text { Per cent of } \\
\text { respondents } \\
(\%)\end{array}$ \\
\hline Less than 5 & 0 & 0 & 0 & 0 & 1 & 0 \\
\hline $5-9$ & 75 & 8 & 17 & 0 & 12 & 4 \\
\hline $10-19$ & 93 & 2 & 3 & 2 & 60 & 18 \\
\hline 20 and over & 76 & 15 & 9 & 0 & 252 & 75 \\
\hline Not stated & 60 & 20 & 10 & 10 & 10 & 3 \\
\hline Total & 79 & 12 & 8 & 1 & 335 & 100 \\
\hline
\end{tabular}

Source: Polish survey. 
Table 5.A3 Language spoken at home by country of birth and age

\begin{tabular}{|c|c|c|c|c|c|c|}
\hline \multirow{2}{*}{$\begin{array}{l}\text { Language } \\
\text { spoken at } \\
\text { home }\end{array}$} & \multicolumn{4}{|c|}{ Born in $(\%)$} & \multicolumn{2}{|c|}{ Respondents } \\
\hline & $\begin{array}{l}\text { Poland } \\
\text { (\%) }\end{array}$ & $\begin{array}{l}\text { Australia } \\
(\%)\end{array}$ & $\begin{array}{l}\text { Other } \\
(\%)\end{array}$ & $\begin{array}{l}\text { Not } \\
\text { stated } \\
(\%)\end{array}$ & $\begin{array}{l}\text { Count } \\
\text { (no.) }\end{array}$ & $\begin{array}{l}\text { Per cent of } \\
\text { respondents } \\
\text { (\%) }\end{array}$ \\
\hline English only & 54 & 36 & 10 & 0 & 70 & 21 \\
\hline Polish only & 93 & 3 & 4 & 0 & 74 & 22 \\
\hline English and & 82 & 7 & 9 & 2 & 186 & 56 \\
\hline Other & 60 & 20 & 20 & 0 & 5 & 2 \\
\hline Total & 79 & 12 & 8 & 1 & 335 & $100^{\circ}$ \\
\hline \multirow{2}{*}{$\begin{array}{l}\text { Language } \\
\text { spoken at } \\
\text { home }\end{array}$} & \multicolumn{4}{|c|}{ Age groups (years) } & \multicolumn{2}{|c|}{ Respondents } \\
\hline & $\begin{array}{l}<29 \\
(\%)\end{array}$ & $\begin{array}{l}30-54 \\
(\%)\end{array}$ & $\begin{array}{l}55-64 \\
(\%)\end{array}$ & $\begin{array}{l}<65 \\
(\%)\end{array}$ & $\begin{array}{l}\text { Count }^{\mathrm{a}} \\
\text { (no.) }\end{array}$ & $\begin{array}{l}\text { Per cent of } \\
\text { respondents } \\
(\%)\end{array}$ \\
\hline English only & 7 & 40 & 33 & 19 & 70 & 21 \\
\hline Polish only & 10 & 32 & 19 & 35 & 74 & 22 \\
\hline $\begin{array}{l}\text { English and } \\
\text { Polish }\end{array}$ & 4 & 33 & 29 & 30 & 186 & 56 \\
\hline Other & 0 & 20 & 40 & 40 & 5 & 2 \\
\hline Total & 6 & 34 & 28 & 29 & 335 & $100^{b}$ \\
\hline
\end{tabular}

a This count also includes all those who did not state their age (11 people or 3 per cent of the sample). Thus, percentages in rows may not add up to 100 per cent.

b Percentages of respondents do not add to 100 per cent due to rounding errors.

Source: Polish survey. 


\section{ENDNOTES}

1 Australian Bureau of Statistics (ABS) 2007, Year Book Australia, 2007, 1301.0-24/01/2007, Australian Bureau of Statistics, Canberra.

2 Ibid.

3 In the 1980s and 1990s, the annual contribution of net migration to population growth in Australia varied between 17 per cent (1992-93) and 56 per cent (1987-88 and 1988-89). This strong inflow has continued in the 2000s. Between 1996 and 2006, the number of Australians born overseas increased, on average, by 1.5 per cent per annum while the Australia-born population increased by 1.1 per cent and total population by 1.2 per cent (ABS, Migration, Australia, 2005-06).

4 ABS, 2006 Community Profile Series, Cat. no. 2003.0, Australian Bureau of Statistics, Canberra, Table T01.

5 ABS, Year Book Australia, 2007.

6 Jupp, J. 1995, ‘Ethnic and cultural diversity in Australia', Year Book Australia, 1995, 1301.0-1/01/1995, Australian Bureau of Statistics, Canberra.

7 Hugo, J. G. 2002, 'Centenary article-a century of population change in Australia', Year Book Australia 2002, 1301.0-2002, Australian Bureau of Statistics, Canberra, p. 11.

8 Ibid.

9 ABS, Year Book Australia, 2007, Table 5.40.

10 ABS 2007, Migration, Australia, 2005-06, 3412.0-29/03/2007, Australian Bureau of Statistics, Canberra.

11 ABS 2004, Year Book Australia, 2004, 1301.0-27/01/2004, Australian Bureau of Statistics, Canberra.

12 The third longitudinal survey of immigrants to Australia, for example, has focused mainly on recent migrant employment, qualifications, earnings, asset transfers, location, housing and command of English. However, it also reports the degree of migrant satisfaction with 'Australian life' (for example, the extent of feeling welcome and the ease of settling into Australian society). The survey shows very high levels of satisfaction (96-98 per cent) (2007, New Migrant Outcomes, Results from the Third Longitudinal Survey of Immigrants to Australia, Commonwealth of Australia, Canberra, August 2007).

13 This study was funded by a special research grant provided by the University of New South Wales. Detailed (10 pages, 63 variables) postal questionnaires were circulated through the Polish Community
Councils. All responses were anonymous and questionnaires were designed to be completed in English in about 20 minutes. Of the many people who helped to circulate the questionnaire, this author would like to acknowledge special assistance of Messrs Arkadjusz Fabjanowski (ACT), Jerzy Krajewski (NSW), Krzysztof Lancucki (VIC), Leszek Wikarjusz (QLD), Krzysztof Balcerzak (SA), Aleksander Gancarz (ACT) and Dr Halina Zobel-Zubrzycka (ACT). He also wishes to acknowledge the assistance of Ms Rissa Raymundo and Ms Nives Klesnik, who coded the responses, checked the consistency of the main data matrix and transformed it into the SPSS format, and Dr Sandra Burchill, who used the SPPS Win PC V14 package to cross-tabulate the data. Professor Marek Okolski of the University of Warsaw and Dr Terri Joiner of La Trobe University offered many useful comments on the format and content of the questionnaire and data processing.

14 A further 25 questionnaires were received, most of which were returned blank either because of being wrongly addressed or because addressees declined to complete them but nevertheless sent them back. Descriptive responses were in part post-coded to enter into the main database and in part recorded on their original format in a separate database. While the rate of response was high (nearly 33 per cent), given the nature of questionnaire distribution, the sample was biased in that the majority of respondents were either Poland-born, first-generation immigrants or those members of the Australia-born second generation who had strong enough 'Polish identity' to be included in the councils' mailing lists. In particular, the sample excluded all those second and thirdgeneration Australians of Polish ancestry who had no direct involvement with the Polish Community Councils.

15 ABS, Year Book Australia, 2004.

16 Rubenstein, K. 2008, 'From supranational to dual alien citizen: Australia's ambivalent journey', in S. Bronitt and K. Rubenstein (eds), Citizenship in a postnational world: Australia and Europe compared, Law and Policy Paper, no. 29, Centre for International and Public Policy, The Federation Press, Canberra, p. 40.

17 See Nolan and Rubenstein elsewhere in this volume .

18 However, as the concept of 'Australian citizenship' is not included in the Australian Constitution, the power of the Commonwealth to enact laws about Australian citizenship derives primarily from the 'alien's power'. It is thus possible for those who are defined as 'aliens' (that is, those who owe an obligation to a sovereign power other than Australia) to be citizens and aliens at the same time. This applies to all dual citizens (Rubenstein, 'From supranational to dual alien citizen'). 


\section{Citizenship and integration}

19 Berkovic, N. 2008, 'Howard's migrant test to be dumped', The Weekend Australian, 22-23 November 2008.

20 See Nolan and Rubenstein elsewhere in this volume.

21 Senator Evans, Immigration Minister, cited in Berkovic, 'Howard's migrant test to be dumped'.

22 Rubenstein, 'From supranational to dual ålien citizen', p. 49.

23 Indeed, the extent to which migrant communities have been able to voice their particular concerns about 'national common values' is itself a measure of Australia's openness as a host country, as such groups have no voice in less tolerant societies.

24 Hugo, 'Centenary article'.

25 Children born in Australia acquire Australian citizenship at birth, if at least one parent is an Australian citizen or a permanent resident of Australia, while those born overseas may be registered as Australian citizens by descent if at least one of their parents is an Australian citizen (ABS, Year Book Australia, 2004). The propensity to acquire Australian citizenship increases, ceteris paribus, with the age of immigrants and the length of their residence in Australia. For example, in 2001, Greece-born residents had a 97 per cent citizenship rate as 83 per cent of them arrived in Australia before 1971 and 75 per cent were at least fifty years old (ibid., Table 5.52).

26 Ibid., Table A2, p. 94.

27 However, this simple concept becomes somewhat blurred when an overseas-born person is registered at birth as an Australian citizen. In this paper, as in most census-based publications, the concept of 'overseas-born' residents of Australia tends to imply the first-generation immigrants rather than foreignborn, 'returned' Australians.

28 For example, Poland lost a large part of its territory to its eastern neighbours but expanded westward by taking over some former German lands. An ethnic Pole born in the pre-World War II Polish city of Lvov, which is now a part of Ukraine, is likely to describe himself/herself as a Polish person born in Poland. However, an ethnic Ukrainian born in the pre-1939 Lvov is likely to describe himself/herself as a Ukrainian person born in Ukraine. On the other hand, an ethnically Jewish person born in Lvov, who may resent the notion of being referred to as either 'Polish' or 'Ukrainian', may be indifferent between being labelled 'Poland-' or 'Ukraine-born'. For example, of the 22600 people who stated their ancestry as Jewish in the 2001 Census, 7 per cent gave their place of birth as Poland and 8 per cent as Ukraine (ABS 2003, Australian Social Trends, 2003, 4102.0-03/06/2003, Australian Bureau of Statistics,
Canberra). Ukraine became an independent nation only after the collapse of the USSR.

29 The chosen self-description may also depend on the prevailing 'sentiment' and social climate in the destination country. For example, some ethnically German DPs who arrived in Australia in the late 1940s were reluctant to declare Germany as their country of birth as they did not wish to be identified with the country's Nazi past - that is, a Danzig or Breslau-born ethnically German person could easily describe his/her country of birth as Poland.

30 ABS 1999, Standards for Statistics on Cultural and Language Diversity, 1999, 1289.0-22/11/1999, Australian Bureau of Statistics, Canberra.

31 Bureau of Immigration Research (BIR) 1991, Community Profiles Poland Born, Statistics Section, Bureau of Immigration Research, Canberra, Table 16, p. 35 .

32 A question on 'ancestry' was first asked in the 1986 Census (Jupp, 'Ethnic and cultural diversity in Australia'). This question had not been included in the census until 2001 when 93 per cent of the population responded to the 'What is the person's ancestry?' question (ABS, Australian Social Trends, 2003).

33 The proportion of the Australian population who reported more than one ancestry increased from 12 per cent in 1986 to 22 per cent in 2001 (ABS, Year Book Australia, 2007). In 2001, nearly one-quarter of those who declared their ancestry as Australian also stated another ancestry (for example, English, 13 per cent, and Irish, 3 per cent, of all Australian ancestry groups).

34 ABS, Australian Social Trends, 2003.

35 Ibid.

36 Of those who stated their ancestry as 'Polish' in the 2001 Census, 49.8 per cent were Australia-born, 34.1 per cent were Poland-born, 5.8 per cent were Germany-born, 2.1 per cent were UK-born, with 0.7 per cent born in New Zealand, 0.7 per cent in the United States, 0.5 per cent in Israel, 0.4 per cent in France, 0.4 per cent in South Africa, 0.3 per cent in Austria and 0.3 per cent in 'Other' countries.

37 For example, in the 1986 Census, only 6 per cent (900 000) of respondents described their ancestry as 'Irish'. But the Irish ancestry group increased to 1 920000 people (more than 11 per cent) in the 2001 Census.

38 However, the Poland-born population also includes small groups that describe their ancestry as Jewish, German and Ukrainian.

39 ABS, Year Book Australia, 2007, Table 12.35.

40 Ibid.

41 Ibid., Table 12.36 
42 BIR, Community Profiles Poland Born.

43 Ibid. , p. vi.

44 ABS 1991, 'Recent trends in overseas migration', Australian Economic Indicators, Oct 1991, 1350.0-18/11/1991, Australian Bureau of Statistics, Canberra, Table 2.

45 Ibid.

46 The age distribution of this population reflects the influence of the two migrant waves: nearly 37 per cent of Poland-born in 2006 were aged sixty-four and over, 37 per cent were aged forty-five-sixtyfour, 20 per cent were aged twenty-five-forty-four, and 6 per cent were aged twenty-four or younger (ABS, 2006 Census of Population and Housing, Census Tables, Table 'Country of Birth of Person by Age by Sex').

47 ABS 2007, 2006 Census of Population and Housing, Census Tables, Cat. no. 2068.0, Australian Bureau of Statistics, Canberra, Table 'Country of Birth of Person by Year of Arrival in Australia'.

48 Ibid.

49 Department of Immigration and Citizenship (DIC) 2007, Immigration Update, July-December 2006, Research and Statistics Section, Department of Immigration and Citizenship, Canberra, Table 1.7, pp. 20-1.

50 ABS, Migration, Australia, 2005-06.

51 Bunda, M. 2006, 'Wielki odjazd [Big departure]', Polityka, vol. 8, 2006.

52 DIC, Immigration Update, July-December 2006.

53 However, there was also a more modest outflow of temporary job seekers to North America (ibid.).

54 See Carrington, K., McIntosh, A. and Walmsley, J. (eds) 2007, The Social Costs and Benefits of Migration into Australia, Centre for Applied Research in Social Sciences, University of New England, Armidale.

55 Productivity Commission 2006, Economic impacts of migration and population growth, Productivity Commission Research Report, Productivity Commission, Australian Government, Melbourne, 24 April 2006.

56 Organisation for Economic Cooperation and Development (OECD) 2002, International Mobility of the Highly Skilled, Organisation for Economic Cooperation and Development, Paris.

57 Hugo, 'Centenary article', p. 14.

58 DIC 2007, Emigration 2006-07 Australia, Programme Statistics and Monitoring Section, Department of Immigration and Citizenship, Canberra, Table 6.

59 Ibid., Tables 1.10 and 1.13, pp. 24-5, 29.
60 BIR, Community Profiles Poland Born, Tables 1-2, pp. 1-2.

61 ABS 2008, 2006 Census Data by Location, 2006 Census Tables, Australian Bureau of Statistics, Canberra, Table 20680.

62 'A normal immigration pattern is for arrivals to be in their mid-twenties and to produce most of their children after arrival' (Jupp, 'Ethnic and cultural diversity in Australia'). For example, in 1959, 68 per cent of settlers were twenty-nine or younger and, in 1990, 59 per cent were (ABS, 'Recent trends in overseas migration', Australian Economic Indicators, Oct. 1991).

63 For example, of those who stated their ancestry as Polish in 2001, nearly 7.5 per cent gave 'Australi$\mathrm{an}^{\prime}$ as their other ancestry.

64 ABS, Year Book Australia, 2004, Tables 2.6 and 2.7 , pp. 22-3.

65 Ibid., Table 4.1, p. 46.

66 Ibid., Table 4.2, p. 50.

67 Department of Immigration and Multicultural and Indigenous Affairs (DIMIA) 2003, Statistical Focus, 2001: Classification of countries into English proficiency groups, C01.2.0, Department of Immigration and Multicultural and Indigenous Affairs, Canberra, July 2003.

68 Ibid, Tables 1 and 2, pp. 16, 19.

69 ABS, 2006 Census of Population and Housing, Census Tables, Table 'Country of Birth of Person by Proficiency in Spoken English/Language by Sex'.

70 ABS 2002, Australian Social Trends, 2002, 4102.0-09/05/2002, Australian Bureau of Statistics, Canberra.

71 Some 2 per cent did not state their proficiency. 72 ABS, Australian Social Trends, 2002, Table A.1:90; and ABS, Year Book Australia, 2007, Table 12.35.

73 There were more than 3.7 million Catholics in Australia in 2001, of whom 74 per cent were Australia-born (DIMIA 2003, The People of Australia, Statistics from the 2001 Census, Department of Immigration and Multicultural and Indigenous Affairs, Canberra, July 2003, Table 10, p. 48).

74 BIR, Community Profiles Poland Born.

75 For example, in 2001-02, only 328 Poland-born people acquired Australian citizenship (ABS, Year Book Australia, 2004, Table 5.53).

76 Ibid., Table 1.1.

77 Ibid., Table A.2, p. 92. 
78 Also, as some of those Poland-born people are not Polish, they may hold dual citizenship with countries other than Poland.

79 Some 3 per cent did not state how they became Australian citizens.

80 Travelling to Poland on a Polish passport simplifies entry requirements while the use of an Australian passport is advantageous on re-entry to Australia.

81 Some 44 per cent of Polish passport-holders are aged thirty-fifty-four, 29 per cent are fiftyfive-sixty-four and 20 per cent are over sixty-five.

82 During parliamentary elections in Poland, polling stations are open at Polish consular offices overseas.

83 The 'Other' category included self-descriptions such as: 'I am an Australian of Polish descent', 'I am primarily Australian but proud of my Polish heritage', 'Of Polish descent, born in England, now living in Europe', 'Australian-Polish-Latvian', 'Australian with Polish parents', 'Australian with dual nationality and Polish background', and the aforementioned, 'By birth: Canadian, by citizenship: Australian, by parentage: Anglo-Polish, by culture: Polish, by upbringing: European'.

84 Some 11 people or 3 per cent of the sample did not state their age.

85 ABS, 2006 Census of Population and Housing, Census Tables, Table 'Country of Birth of Persons by Age by Sex'.

86 Four people did not state their country of birth. 
